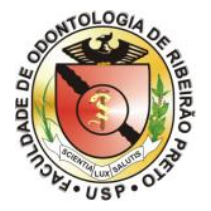

DANIELA NAIR BORGES FELIPUCCI

AVALIAÇÃO DA FORÇA DE RETENÇÃO DE ENCAIXES O'RING SUBMETIDOS A SOLUÇÕES DE HIGIENIZAÇÃO DIÁRIAS 

UNIVERSIDADE DE SÃO PAULO

FACULDADE DE ODONTOLOGIA DE RIBEIRÃO PRETO

DANIELA NAIR BORGES FELIPUCCI

AVALIAÇÃO DA FORÇA DE RETENÇÃO DE ENCAIXES O'RING SUBMETIDOS A SOLUÇÕES DE HIGIENIZAÇÃO DIÁRIAS

RIBEIRÃO PRETO 

DANIELA NAIR BORGES FELIPUCCI

\section{AVALIAÇÃO DA FORÇA DE RETENÇÃO DE ENCAIXES O'RING SUBMETIDOS A SOLUÇÕES DE HIGIENIZAÇÃO DIÁRIAS}

Tese de Doutorado, apresentada à

Faculdade de Odontologia de Ribeirão

Preto da Universidade de São Paulo,

Departamento de Materiais Dentários e Prótese.

Área de Concentração: Reabilitação Oral

Orientadora: Profa. Dra. Valéria O. Pagnano de Souza 
AUTORIZO A REPRODUÇÃO E DIVULGAÇÃO TOTAL E PARCIAL DESTE TRABALHO, POR QUALQUER MEIO CONVENCIONAL OU ELETRÔNICO, PARA FINS DE ESTUDO E PESQUISA, DESDE QUE CITADA A FONTE.

\section{FICHA CATALOGRÁFICA}

Ficha catalográfica elaborada pela Biblioteca Central do Campus da USP - Ribeirão Preto

Felipucci, Daniela Nair Borges

Avaliação da força de retenção de encaixes o'ring submetidos a soluções de higienização diárias.

Ribeirão Preto, 2013.

137 p.: $1811 .: 30 \mathrm{~cm}$

Tese de Doutorado, apresentada à Faculdade de Odontologia de Ribeirão Preto da Universidade de São Paulo, Departamento de Materiais Dentários e Prótese. Área de Concentração: Reabilitação Oral.

Orientadora: Pagnano, Valéria Oliveira.

Palavras-chave: 1. Higienizadores de Dentadura. 2. Overdentures. 3. Encaixe de Precisão de Dentadura. 


\section{AVALIAÇÃO DA FORÇA DE RETENÇÃO DE ENCAIXES O'RING SUBMETIDOS A SOLUÇÕES DE HIGIENIZAÇÃO DIÁRIAS}

Tese de Doutorado, apresentada à Faculdade de Odontologia de Ribeirão Preto da Universidade de São Paulo, Departamento de Materiais Dentários e Prótese.

Área de Concentração: Reabilitação Oral

\section{BANCA EXAMINADORA}

Prof. Dr.

Instituição:

Julgamento:

Assinatura:

Prof. Dr.

Instituição:

Julgamento:

Assinatura:

Prof. Dr.

Instituição:

Julgamento:

Assinatura:

Prof. Dr.

Instituição:

Julgamento:

Assinatura:

Prof. Dr.

Instituição:

Julgamento:

Assinatura: 

Dedicatóría 

Aos meus pais,

que estiveram juntos comigo em mais esta etapa, amparando-me, acolhendome, aconselhando-me e me incentivando nos momentos de cansaço. Sei do orgulho que têm de assistir meu doutoramento, mas nada eu seria se não tivesse o apoio e exemplo de luta constante de vocês.

Ao meu irmão e cunhada,

que sabem bem o que a vida acadêmica representa, e me servem de inspiração para seguir a docência. Os conselhos duros e práticos do meu irmão, como sempre, são capazes de me trazer à realidade dos fatos e encarar os desafios de cabeça erguida.

\section{À minha avó,}

que passou por desafios tão maiores que os meus, e me fez entender que adiar a resolução dos problemas nunca é a melhor solução. Exemplo de luta e perseverança, conseguiu, do alto da sua sabedoria, amparar-me em situações que nem ela saberia ser capaz. Ser admirada e apoiada nas minhas decisões por ela é uma das únicas coisas na vida que realmente me importam. É uma honra poder carregar seu nome.

Aos meus familiares,

que acompanharam minha trajetória mesmo que à distância, e entenderam que esse degrau precisava ser galgado para que os meus objetivos maiores pudessem ser atingidos. E me admiram por isso.

Aos meus amigos,

que entenderam os momentos que tive que me ausentar para que pudesse conciliar trabalho e pesquisa, e que me fizeram companhia nos momentos em que eu precisava me distrair para ganhar fôlego.

"Todos os dias ao me levantar, piso na minha vaidade para que ela não me desvie do meu caminho." 

Agradecímentos especíaís 



\section{A Deus,}

meu companheiro do dia-a-dia, razão da minha existência e meu maior investidor. Agradeço todos os desafios propostos nestes últimos anos, pois graças a eles pude me tornar uma pessoa mais madura, mais resolvida e melhor. $E$ continuo a pedir que não me dê menos problemas, e sim, mais sabedoria. Agradeço pela saúde, lucidez, resistência emocional e por todas as janelas que me foram abertas, após algumas portas fechadas.

À minha orientadora, Profa. Dra. Valéria Oliveira Pagnano de Souza,

pois fechamos juntas mais este ciclo, que foi repleto de desafios, mas também de oportunidade de crescimento. Este período, além de toda a orientação e colaboração técnica e científica, foi marcado por uma mulher forte, que parou sua vida cheia de compromissos apenas para ouvir meus desabafos e me amparar nos momentos de dificuldades. Que entendeu algumas limitações com a pesquisa, por me enxergar como um ser humano que também falha e enfrenta adversidades. Agradeço por sempre estar aberta e prestativa. Agradeço por ter me aceitado também no Doutorado, e ter me ajudado a realizar o sonho desta conclusão. É uma honra fazer parte da sua história, sendo sua primeira orientada de Mestrado e Doutorado. 



\section{Agradecimentos}





\section{À Faculdade de Odontologia de Ribeirão Preto e Departamento de Materiais}

Dentários e Prótese, pela formação, pelos padrões de exigência e excelência. Tenho muito orgulho em carregar a bandeira forpiana a cada lugar que eu vá.

A todos os Mestres que passaram por minha formação acadêmica e de docência pelos conhecimentos compartilhados e pelos exemplos a serem seguidos, de paixão e dedicação à carreira.

\section{À Prof. Dra. Helena de Freitas Oliveira Paranhos e Prof. Dr. Raphael Freitas de} Souza pela presteza nas orientações metodológicas e científicas, pelo incentivo e convivência.

Ao Prof. Dr. Luiz Geraldo Vaz e Prof. Dr. José Maurício Reis, por compartilharem suas ideias e esclarecerem dúvidas pertinentes à realização deste trabalho, além de permitirem o uso do laboratório de ensaios mecânicos da Faculdade de Odontologia de Araraquara - UNESP.

À Prof. Dra. Cláudia Helena Lovato da Silva pelo carinho e atenção que sempre me recebeu, por se importar com minha trajetória e, ainda, por relatar com tanto cuidado meu Projeto de Pesquisa.

Ao Prof. Dr. Osvaldo Luiz Bezzon pelas ajudas sempre assertivas nos momentos de dúvidas e pelo direcionamento constante.

Ao Prof. Dr. Wellington Cardoso Bonachela, que se prontificou a me ajudar quando perdi meus resultados, na repetição do experimento, e que muitas vezes me aconselhou em dificuldades na condução do trabalho.

À Prof. Dra. Fernanda Panzeri de Carvalho, que na posição de coordenadora do Programa de Pós graduação em Reabilitação Oral do Departamento de Materiais Dentários e Prótese, acolheu-me como aluna e, desde então, contribuiu com minha formação, inclusive compreendendo as dificuldades quanto à realização deste trabalho.

Ao Prof. Dr. Rômulo Rocha Regis e à especialista em laboratório, Ana Paula Macedo, pela ajuda de fundamental importância na análise estatística deste trabalho. 
À banca julgadora que aceitou o convite de participar deste momento tão importante que é a defesa da minha tese para obtenção do título de Doutora em Reabilitação Oral pela FORP-USP.

Ao técnico Luiz Sérgio Soares, meu querido Professor Pardal, por toda a atenção na fase de planejamento deste trabalho e por trazer à realidade as ideias que estavam em nossa cabeça.

Ao técnico Otávio Terra da Oficina de Precisão do Campus da USP de Ribeirão Preto, que me recebeu com muita atenção, quando foi necessário substituir as matrizes e dispositivos dos ensaios mecânicos, tendo realizado tudo com extrema agilidade para me ajudar.

À empresa Dabi Atlante/PROSS por ter apoiado a minha pós-graduação, principalmente nas pessoas dos meus gestores Fábio Ferrari e Wesley Carvalho de Almeida.

À pós-graduanda Luciana Costa Crizóstomo, que foi meu braço direito na finalização deste trabalho e tem papel fundamental no resultado obtido.

À pós-graduanda Carolina Noronha de Arruda, pela gentileza e ajuda de extrema importância na busca literária.

Aos amigos da Pós-Graduação, Adriana Ribeiro, Ana Carolina Maito Villela, Ana Paula Terossi de Godoi, Diogo Rodrigues Cruvinel, Fábio Afrânio, Jerônimo Gonçalves, Maria Paula Della Vecchio, Marina Xavier Pisani, Murilo Sucena Pitta, Rander Moreira, Rômulo Rocha Régis e Tatiana Ramirez Cunha pela convivência, amizade e companheirismo.

Aos técnicos de laboratório, Eduardo Destito, Fernando Schiavetto, José de Godoi Filho, Lício Firmino Junior, Marcelo Vieira, Odair Rosa Silva, Paulo Sérgio Ferreira pelo suporte técnico e mais que isso, pela amizade e carinho no decorrer desta vivência.

Às secretárias do Departamento de Materiais Dentários, Ana Paula Xavier, Fernanda Talita de Freitas e Regiane Damasceno Tirado, pelo convívio e disponibilidade, além da presteza de sempre. 
Às secretárias da Seção de Pós-Graduação, Regiane Moi e Isabel Sola, pela presteza.

À empresa Conexão Sistemas de Prótese pelo material cedido para a realização do Projeto de Pesquisa.

A todos que contribuíram direta ou indiretamente em qualquer momento desta trajetória. 



\section{RESUMO}

FELIPUCCI, D.N.B. Avaliação da força de retenção de encaixes o'ring submetidos a soluções de higienização diárias. 2013. 137f. Tese (Doutorado) Faculdade de Odontologia de Ribeirão Preto, Universidade de São Paulo, Ribeirão Preto.

Soluções auxiliares para higienização de próteses têm sido indicadas como método efetivo no controle de biofilme. Desta forma, este estudo teve por objetivo avaliar se as soluções (Cepacol/C, Cepacol Flúor/CF, Listerine/L, hipoclorito de sódio $0,05 \% / \mathrm{HS}$ e água deionizada/AD, como controle) potencializam a perda de retenção do o'ring (Conexão Sistemas de Prótese Ltda). Foi obtida uma base de teflon com dois análogos e pilares o'ring e contra-bases, compostas pelas cápsulas metálicas e anéis, foram confeccionadas e divididas em grupos $(n=6)$. Foram simulados 90 dias de imersão overnight, sendo obtido o valor da resistência à tração a cada 30 dias, utilizando a máquina de ensaios mecânicos (Material Testing System - MTS 810), totalizando 4 leituras (T0, T1, T2 e T3). Foi realizada análise qualitativa por meio de microscopia eletrônica de varredura em um espécime de cada grupo. Os dados da força de retenção $(\mathrm{N})$ foram analisados estatisticamente pelos testes ANOVA e Bonferroni $(\alpha=0,05)$. Os resultados demonstraram que a retenção diminuiu significativamente com o tempo ( $P=0,0001)$ e com o uso das soluções $(P=0,0000)$ e houve interação entre os fatores de variação $(P=0,0245)$. A retenção no T0 $(11,25)$ foi maior que no T1 $(9,63)$, T2 $(8,76)$ e T3 $(8,40)$. No T1 foi maior que nos demais tempos e entre T2 e T3 não houve diferença significante. Entre as soluções avaliadas, o HS causou a maior redução da força de retenção $(7,00)$. Os enxaguatórios $C$ e $L$ propiciaram médias similares (10,41 e 10,09, respectivamente) à $A D(10,91)$. O CF propiciou resistência similar $(9,14)$ aos enxaguatórios $C$ e L. No $C$ e no HS a retenção diminuiu significativamente a partir de 30 dias. No $L$ e no $C F, a$ diminuição da retenção ocorreu após 60 dias. $\mathrm{Na} A D$, a retenção se manteve pelo período de 90 dias. Após 90 dias, o C propiciou retenção similar à água deionizada. As eletromicrografias apontaram alteração dos anéis: no do grupo do HS, houve presença de solução de continuidade do material e no do CF, formação de uma película com precipitados cristalinos. Conclui-se que após 3 meses de imersão, os valores obtidos em todas as soluções se apresentaram acima do mínimo indicado para a retenção $(5 \mathrm{~N})$, entretanto as soluções de hipoclorito de sódio $0,05 \%$ e Cepacol Flúor devem ser evitadas devido aos efeitos deletérios causados no material.

Palavras-chave: Higienizadores de Dentadura, Overdentures, Encaixe de Precisão de Dentadura. 


\begin{abstract}
FELIPUCCI, D.N.B. Evaluation of retention force of o'ring attachments subjected to daily hygiene solutions. 2013. 137f. Tese (Doutorado) - Faculdade de Odontologia de Ribeirão Preto, Universidade de São Paulo, Ribeirão Preto.
\end{abstract}

Denture cleansers have been widely indicated as an effective auxiliary method to biofilm control. The aim of this study was to evaluate the effect of these solutions Cepacol/C, Cepacol Fluor/CF, Listerine/L, 0,05\% sodium hypochlorite/SH and deionized water /DA - control) on the retention loss of overdentures nytril o'rings (Conexão Sistemas de Prótese Ltda). Teflon dies containing 2 implants and abutments and acrylic specimens with the metal caps were obtained and divided into the groups $(n=6)$. Ninety overnight soaks were performed simulating 3 months of care. At each 30 immersions, the peak load of tensile strength was registered (Material Testing System - MTS 810), and 4 tests wereperformed (T0, T1, T2 e T3). Qualitative method by scanning electronic microscopy (SEM) was used for complementary analyzes. The data were statistically analyzed by the ANOVA and Bonferroni tests $(\alpha=0.05)$. The results showed that the retention decreased with time $(P=0.0001)$ and with the use of solutions $(P=0.0000)$ and there was interaction between variation factors $(P=0.0245)$. Retention in T0 (11.25) was higher than in T1 (9.63), T2 (8.76) and T3 (8.40). In T1, the retention was higher than in other times and between T2 and T3 no significant difference. Among the solutions evaluated, the HS caused the greatest reduction in retention force (7.00). The $C$ and $L$ rinses propitiated similar averages (10.41 and 10.09, respectively) to AD (10.91). The CF provided similar resistance (9.14) to $C$ and $L$ rinses $I n C$ and $H S$, the retention decreased significantly from 30 days. In $C F$ and $L$, the retention decrease occurred after 60 days. In AD, the retention was maintained for 90 days. After 90 days, $\mathrm{C}$ promoted retention similar to deionized water. The electron micrographs showed alteration of the rings: in HS group, there was presence of a discontinuity of the material and in CF, there was a film forming with crystalline precipitates. It can be concluded that after 3 months of immersion, the values of all the solutions were above the minimum suitable for retaining $(5 \mathrm{~N})$, however, solutions of sodium hypochlorite $0.05 \%$ and Cepacol Fluor should be avoided due to deleterious effects on the material.

Key words: Denture Cleansers, Overdentures, Denture Precision Attachment. 


\section{SUMÁRIO}

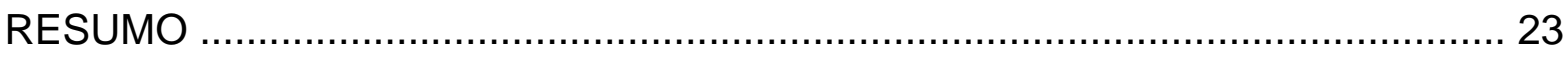

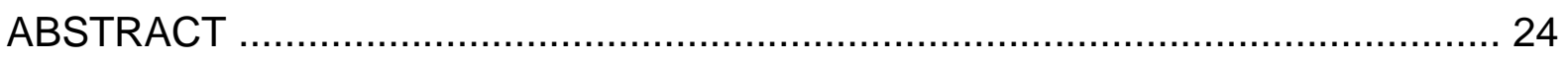

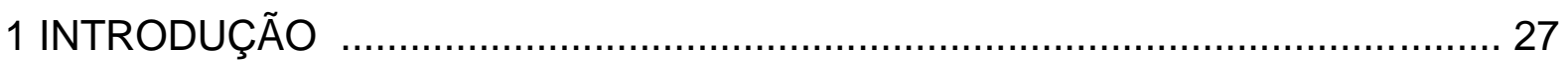

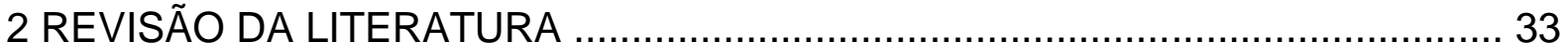

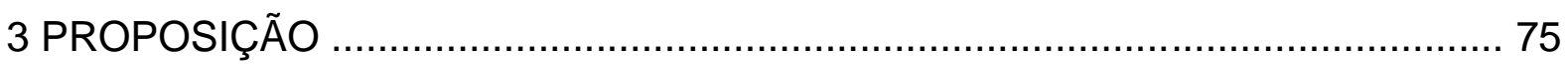

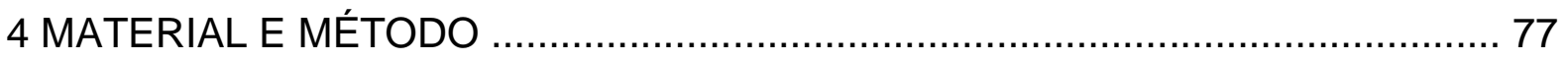

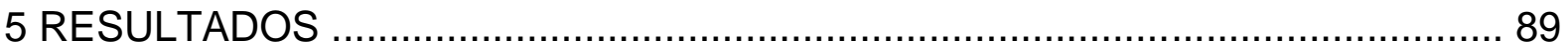

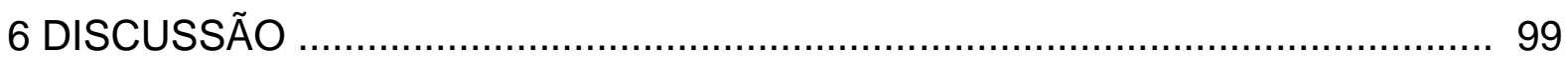

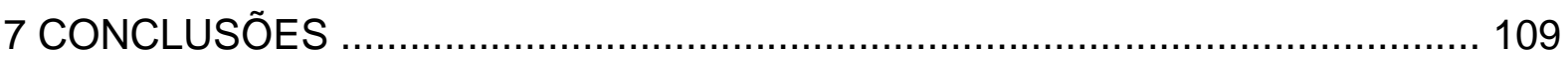

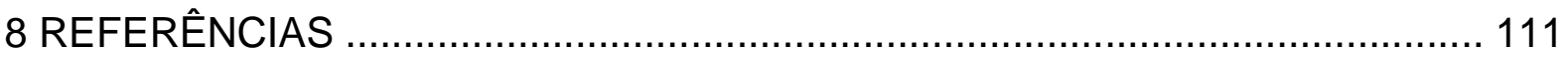

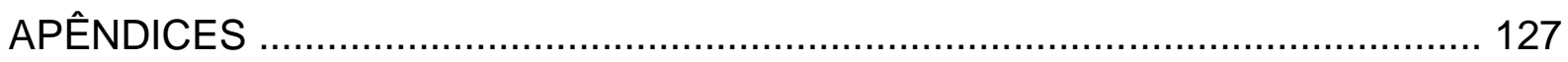



1 introdução 
Com o advento dos implantes osseointegrados, houve uma diversificação nas opções de tratamento do edentulismo, antes praticamente restritas às próteses de suporte mucoso e/ou dentário. Entretanto, muitos pacientes edêntulos apresentam condições financeiras, anatômicas ou psicológicas que impedem a instalação de implantes para a fixação rígida de uma prótese do tipo protocolo ou mesmo a permanência de uma prótese removível convencional.

Nos países subdesenvolvidos ou em desenvolvimento, 0 acesso ao tratamento reabilitador baseado em implantes com próteses fixas é praticamente inexistente para pacientes de baixa renda, que, muitas vezes, apresentam dificuldade de adaptação e aceitação de próteses convencionais. Nesses casos, as próteses totais, parciais fixas sobre dentes naturais ou implantes dentários, conhecidas como sobredentaduras ou overdentures são geralmente opções mais viáveis (FATALLA et al., 2012). No Brasil o governo federal, por meio de suas esferas municipais nos Centros de Especialidades Odontológicas (CEOs), disponibiliza o serviço para a população de instalação de próteses overdentures retidas por implantes, regularizado pela da Portaria 718/SAS DE 20/12/2010 (SECRETARIA DE ATENÇÃO À SAÚDE, 2010).

Uma vez que esta opção de tratamento venha a ser mais empregada, a correta instrução de higienização se faz necessária. No entanto, em casos de próteses convencionais observam-se dificuldades em relação à correta manutenção dos aparelhos protéticos. Sabe-se também que, entre os fatores que contribuem para o sucesso do tratamento, a adequada higienização é fundamental para a longevidade do tratamento reabilitador e prevenção de patologias orais, tais como a Candidose Crônica Atrófica, ou Estomatite relacionada à Prótese, que é caracterizada por lesões bucais mais comumente observadas em usuários de próteses removíveis (WALBER; RADOS, 2000; KEYF, GÜNGÖR, 2003; BARBEAU et al., 2003; Entretanto, a instrução de higienização aos pacientes usuários de próteses removíveis gera muitas dúvidas entre os clínicos em geral. Com a prótese na cavidade bucal em contato com os tecidos de suporte, envolvidos pela saliva, com a presença de microrganismos como estreptococos, estafilococos, pseudomonas, enterobactérias e espécies de Candida (NIKAWA, HAMADA, YAMAMOTO, 1998; SESMA et al., 1999; WALBER, RADOS, 2000) e a consequente formação de biofilme, podem ocorrer infecções bucais que variam desde estomatite 
relacionada à prótese quando associadas com trauma local (BARNABÉ et al., 2004) até doenças periodontais, queilite angular, além, é claro, de maus odores (KEYF, GÜNGÖR, 2003).

Os microrganismos colonizam as superfícies intra-orais de maneira rápida e se organizam em biofilme, que pode ser formado em poucas horas (BERGER, EWOLDSEN, 2006). Além disso, a redução do fluxo salivar e a diminuição dos níveis de $\mathrm{pH}$ bucal também são fatores que auxiliam na sobrevivência de microrganismos e na formação de biofilme (MÄHÖNEN, VIRTANEN, LARMAS, 1998; SHIP, PILLEMER, BAUM, 2002; TORRES et al., 2002), o qual depende do suprimento de nutrientes e do grau de higienização bucal. As próteses removíveis, ao entrarem em contato com o meio bucal, tornam-se colonizadas com grande número de microrganismos dentro de 6 horas e essas colônias aumentam significativamente em 48 horas (LAMFON et al., 2003).

Além disso, as irregularidades de superfície e porosidades internas de materiais restauradores oferecem nichos favoráveis à colonização microbiana (JAGGER et al., 2002). A retenção de fungos ocorre não somente na resina acrílica, mas também na superfície da liga metálica devido à rugosidade superficial (SHAY, 2000). Os estudos têm demonstrado que usuários de próteses removíveis apresentam higiene precária (NIKAWA et al., 1999; KULAK-OZKAN, KAZAZOGLU, ARIKAN. 2002; LOVATO-SILVA et al., 2006; RIBEIRO et al., 2009; PARANHOS et al., 2009; PERACINI et. al, 2010). Isto pode ser devido ao fato de que a maioria destes pacientes não recebe orientações suficientes quanto à limpeza dos aparelhos protéticos (PARANHOS et al., 2000). Além disso, as características anatômicas das próteses e a diminuição da coordenação motora em razão da idade são fatores que devem ser considerados na avaliação da higiene realizada pelo paciente (LOVATOSILVA et al., 2006).

O método ideal de limpeza deve ser efetivo na remoção de pigmentos e depósitos orgânicos e inorgânicos, bactericida e antifungicida, compatível com qualquer um dos materiais utilizados no aparelho protético, atóxico, ter baixo custo e facilidade de uso (ABERE, 1979; BUDTZ-JØRGENSEN, 1979; ABELSON, 1981; COUNCIL ON DENTAL MATERIALS, INSTRUMENTS AND EQUIPMENT, 1983; ABELSON, 1985; JAGGER, HARRISON, 1995; SESMA et al., 1999; SHEEN, 
HARRISON, 2000). Segundo Tarbet et al. (1984) o agente de limpeza deve ser capaz de remover o biofilme tanto das superfícies polidas, como das superfícies não polidas das próteses.

Os métodos de higienização existentes são: mecânico, químico, associação dos dois métodos e utilização de aparelhos ultrassônicos (BUDTZJØRGENSEN, 1979; ABELSON, 1981; COUNCIL ON DENTAL MATERIALS, INSTRUMENTS AND EQUIPMENT, 1983; JAGGER, HARRISON, 1995; NIKAWA et al., 1999). O método mais utilizado é a associação de escovas dentais com sabão neutro ou dentifrício. Este método exige destreza manual e não remove completamente o biofilme com os microrganismos, sendo o método químico melhor neste quesito (SHAY, 2000; SHEEN, HARRISON, 2000). A associação de escovação com a imersão em soluções higienizadoras tem sido indicada como melhor opção, pois as soluções alcançam facilmente todas as áreas da prótese, resultando em higienização completa, não ocorre abrasão, a manipulação é simples, facilmente realizada por pacientes portadores de necessidades especiais, como também por aqueles com falta de coordenação motora para higienizar adequadamente a prótese por escovação (ABERE, 1979; AUGSBURGER, ELAHI, 1982; DILLS et al., 1988; CHAN et al., 1991; NIKAWA et al., 1999).

A overdenture ou sobredentadura é uma prótese retida por raízes ou implantes, os quais possuem encaixes que são dispositivos mecânicos para fixação, retenção e estabilização de uma prótese dentária. Este conceito foi originado na Suíça por volta de 1898 e foi popularizada por Gilmore há 60 anos (PETROPOULOS, MANTE, 2011). Alguns métodos têm sido propostos para fazerem a conexão entre as próteses e os implantes osseointegráveis, entre eles o sistema de barra e clipes, os encaixes do tipo bola (o'ring) e magnetos (MACHADO et al., 2011; BURNS et al., 2011; SUZUKI, OHKUBO, KURTZ, 2013).

O tratamento por meio de overdentures retidas por implantes pode variar pela utilização de 2 a 4 implantes e caracteriza uma modalidade efetiva para pacientes edêntulos, principalmente quando for considerado o edentulismo mandibular, sobretudo por aumentar o nível de retenção e por facilitar a acomodação daqueles pacientes que apresentam dificuldade de adaptação àas próteses totais convencionais (BURNS et al., 2011; BILHAN et al., 2011). 
As overdentures oferecem conforto, estética e função mastigatória, tendo propiciado melhor qualidade de vida aos indivíduos totalmente edêntulos (EPSTEIN et al., 1999; VAN DER BILT et al., 2010; RUTKUNAS et al., 2011). Alguns métodos têm sido propostos para fazerem a conexão entre as próteses e os implantes osseointegráveis, entre eles o sistema de barra e clipes, os encaixes do tipo bola (o'ring) e magnetos (MACHADO et al., 2011; BURNS et al., 2011; SUZUKI, OHKUBO, KURTZ, 2013).

Os encaixes o'ring propiciam facilidade de inserção e remoção, higienização mais eficiente, inclusive para pacientes com pouca coordenação motora, baixo custo, melhor fonética, facilidade na manutenção pós-instalação pela substituição periódica apenas do anel de retenção e eliminação da infraestrutura metálica quando comparados com as próteses fixas sobre implantes. Entretanto, há desvantagens como a perda gradual da retenção dos anéis e a necessidade de reposição periódica (BOTEGA et al.,2004; RODRIGUES et al., 2009; VAN DER BILT et al., 2010; RUTKUNAS et al., 2011; BILHAN et al., 2011).

Segundo a literatura, o desgaste dos anéis pode ocorrer devido aos repetidos movimentos de inserção e remoção (WICHMANN, KUNTZE, 1999; RUTKUNAS et al., 2011), além de estar também diretamente relacionados com a necessidade de paralelismo entre os implantes e estar a perpendicular ao plano oclusal pois a trajetória de inserção fora do eixo axial tende a aumentar o desgaste do sistema (RODRIGUES et al., 2009; YANG et al., 2011).

Os estudos demonstram que há alteração da retenção com o uso prolongado do conjunto macho e fêmea (BOTEGA et al., 2004; KARABUDA, YALTIRIK, BAYRAKTAR, 2008; BAYER et al., 2009; RODRIGUES et al., 2009; NGUYEN et al., 2010). Entretanto, nenhum trabalho associou o uso de solução para higienização das próteses com o desgaste do anel de borracha.

Considerando que a literatura é vasta em relação aos efeitos das soluções de higienização nas resinas acrílicas das bases de próteses e nas ligas metálicas (ABELSON, 1981; ABELSON, 1985; ABERE, 1979; BUDTZ-JØRGENSEN, 1979; JAGGER, HARRISON, 1995; SESMA et al., 1999; SHEEN, HARRISON, 2000; KEYF, GÜNGÖR, 2003), seria interessante investigar também o efeito dessas soluções nos componentes dos encaixes utilizados nas overdentures, . 
É possível verificar que na literatura não existem orientações precisas para os profissionais transmitirem para os pacientes (ALLEN, MCMILLAN, SMITH, 1997; LACERDA, 1998; LOVATO-SILVA et al.,2006; PERACINI et al., 2010; ). Geralmente o cirurgião-dentista realiza instruções de higienização mecânica ao paciente, mas não o orienta adequadamente em relação ao método de higienização química diária. Desse modo, é imprescindível que o profissional conheça os métodos de higienização das próteses, tanto mecânicos como químicos, e realize as instruções de forma correta.

Com os resultados obtidos, pode-se orientar de forma mais precisa os profissionais com relação aos métodos de higienização das próteses do tipo overdenture, além de contribuir para a elaboração de um protocolo de higienização diária específico para essas próteses. Observa-se que há dificuldade por parte dos pacientes na manutenção de seus aparelhos protéticos justificada pela precária ou ausente orientação por parte dos profissionais (WAGNER, 1973; HOAD-REDDICK et al., 1990; JAGGER, HARRISON, 1995; LOVATO-SILVA et al., 2006; RIBEIRO et al., 2009; PERACINI et. al., 2010).

Além disso, a rotina clínica demonstra a necessidade de substituição dos anéis de borracha dos sistemas o-ring dentro de uma média de 6 meses, e esta é também a indicação dos fabricantes (SAAVEDRA et al., 2007, VARGHESE et al., 2007) o que vai de encontro, apesar de não ser unânime, a muitos autores que têm relatado a necessidade de manutenção nos sistemas óring particularmente no primeiro ano de uso (ALLEN, McMILLAN, SMITH, 1997; van KAMPEN et al., 2003; WALTON, 2003; NAERT et al., 2004; BILHAN et al., 2011). Este é um período considerado adequado para estudos de avaliação de efeito de soluções de higienização ou desinfecção, sendo possível a análise dos seus possíveis efeitos nos objetos de estudo (NIKAWA et al., 2003; VARGHESE et al., 2007; FELIPUCCI et al., 2011a; FELIPUCCI et al., 2011b, DAVI et al., 2012).

Desta forma, este trabalho tem por objetivo avaliar o efeito de diferentes soluções de higienização diária na retenção dos anéis de borracha do sistema o'ring de overdentures sobre implantes. 
2 Revista da Literatura 
Sexson e Phillips (1951) avaliaram os efeitos dos procedimentos de limpeza sobre a superfície de resinas acrílicas. Previamente aos ensaios laboratoriais, pesquisaram em 370 pacientes portadores de próteses totais, quais os materiais, métodos e frequência de higienização de suas próteses. A maioria respondeu que utilizava dentifrício comum, associado à escovação, duas vezes ao dia. Foram também avaliados os efeitos dos higienizadores de prótese mais usados sobre as resinas acrílicas (base e dentes artificiais), por meio de medidas de perda de peso, mudanças no brilho e exames microscópicos da superfície. Uma máquina de escovação (Pepsodent®) foi empregada, com os corpos-de-prova estáticos ou em rotação, para simular a mudança na trajetória da escovação. Os higienizadores caseiros causaram perda de peso duas vezes maior que os dentifrícios. Agentes variados, como o sabão, a soda e o sal produziram efeitos mínimos. A mudança de brilho e a formação de riscos e cavidades se correlacionaram com os resultados de perda de peso. Os corpos-de-prova estáticos apresentaram a mesma perda de peso que os submetidos à rotação, porém perderam mais brilho, com maior formação de cavidades e riscos. Foi concluído que os produtos caseiros e dentifrícios abrasivos devem ser contra-indicados para a limpeza das próteses, devido aos seus efeitos deletérios que podem tornar a manutenção da higiene mais difícil, devido ao aumento da rugosidade superficial.

Smith (1961) realizou um estudo sobre higienizadores de prótese, avaliando a eficácia na higienização, a possível corrosão e outros efeitos deletérios aos materiais constituintes da prótese. Foram utilizados 20 higienizadores, classificados em três grupos: limpeza por ação abrasiva, por meios químicos e ação química e abrasiva associadas. No primeiro grupo, foram utilizados 3 pós abrasivos suaves. No grupo químico foram avaliados 8 peróxidos alcalinos, 1 hipoclorito alcalino e 6 soluções de ácidos diluídos. No terceiro grupo foi realizada escovação associada a alguns dos higienizadores químicos. Amostras de resina acrílica foram submetidas a estes higienizadores diariamente por um ano, de acordo com as instruções dos fabricantes. O exame visual das amostras revelou pequenos efeitos deletérios, sendo que a imersão não foi efetiva na remoção de depósitos calcificados. Desse modo, os autores recomendaram a escovação associada a higienizadores químicos.

Smith (1966) classificou os agentes de limpeza em pós, soluções de hipocloritos alcalinos, soluções de peróxidos alcalinos, ácidos minerais diluídos e 
pastas. Segundo o autor, embora a escovação rotineira com sabão mantenha a superfície da prótese total polida, existem estudos mostrando a necessidade de um auxílio complementar. $O$ autor relatou que evidências clínicas e comerciais mostravam que higienizadores oxidantes eram muito utilizados, mas que nem sempre eram efetivos. Destacou, então, a necessidade de formulação de um higienizador que solubilizasse rapidamente o depósito sem afetar o material da prótese.

MacCallum et al. (1968) classificaram os higienizadores em dois grupos: soluções higienizadoras (hipocloritos alcalinos, peróxidos alcalinos e ácidos minerais diluídos) e higienizadores abrasivos (pós e pastas). Realizaram uma avaliação dos hábitos de higiene de próteses totais por meio de questionários e exame das próteses. De um total de 1000 pacientes, verificaram que uma ampla variedade de higienizadores era usada, totalizando 34 materiais diferentes, sendo muito utilizado o higienizador peróxido alcalino. Destes 1000 pacientes, somente 175 estavam insatisfeitos com seu método de limpeza da prótese, sendo que 698 possuíam próteses manchadas.

Neill (1968) avaliou a eficácia de higienizadores de prótese e seus possíveis efeitos deletérios. Uma das etapas do estudo consistiu na aplicação de um questionário aos pacientes, revelando os hábitos de limpeza das próteses. No teste clínico, onze higienizadores de próteses totais e abrasivos (Dento®, Dentifresh $\AA$, Sanident $\AA$, Librox $\AA$, Eucry $1 \AA$, Steradent $\AA$, Wernets $\AA$, Dentural $\AA$, Oxydent $\AA$, Kolynos ${ }^{\circledR}$ e Lustredent $\left.{ }^{\circledR}\right)$ foram distribuídos a 76 pacientes durante um período de 5 semanas. No estudo laboratorial, próteses foram confeccionadas e seccionadas, sendo metade utilizada como controle e a outra submetida a procedimentos de higienização (escovação e imersão). Foram realizadas imersões de 8 horas diárias por um período de seis dias. Foi avaliada também a capacidade de limpeza em próteses manchadas. Tanto na avaliação clínica como na laboratorial, foram utilizadas fotografias das próteses ou amostras obtidas antes e após o uso dos higienizadores. O autor concluiu que as imersões em soluções de peróxido alcalino e hipoclorito constituiam um método seguro e efetivo de higienização, e que a escovação foi responsável por causar danos às bases de resina acrílica. Desta forma, ressaltou que devem ser utilizados produtos de baixa abrasividade para higienização das próteses. 
Em 1971, Ashton e Bloch estudaram as soluções de limpeza mais recomendadas para próteses totais e parciais removíveis quanto aos efeitos sobre a mudança no peso, cor, resistência e características da superfície de resinas acrílicas e ligas metálicas. Foram utilizadas duas marcas de resinas (Lucitone® e Pronto®) e duas diferentes ligas metálicas (Ticonium 100® - cobalto-cromo, e ouro tipo IV para fundição) e foram confeccionadas dez amostras de cada material. Após os ensaios as amostras foram fotografadas e pesadas antes e após as nove semanas de imersão e foram também submetidas a um dinamômetro, para verificação da resistência a cargas. Pelo exame fotográfico, nenhuma diferença foi observada nas amostras de resina e ouro. A liga de Ticonium $®$ apresentou pigmentações quando imersa em vinagre e alvejante. Microscopicamente, o alvejante causou deterioração da liga, diminuição da resistência a cargas e perda de peso. Nas resinas, houve pequeno aumento de peso com as soluções, excepcionalmente com o vinagre, houveperda de peso, ou seja, dissolução do acrílico.

Wagner (1973) estudou os materiais e métodos para manutenção da higiene oral de pacientes parcialmente edêntulos. $O$ autor relatou a dificuldade de adaptação dos pacientes e a necessidade da orientação por parte do cirurgião-dentista. Sugeriu a higienização com escova macia associada a sabonete líquido diluído em água (1:9) e a imersão em higienizadores comerciais. O autor ressaltou a importância a escovação após as imersões, para limpar a prótese completamente.

Van Reenen (1973) estudou o papel das bactérias na Candidíase Atrófica Crônica. Encontrou que o número de cocos gram-positivos, incluindo estreptococos, pneumococos e estafilococos, foi maior na mucosa palatina de pacientes com estomatite. Sugeriu que nenhum microrganismo específico estivesse associado às lesões e que a infecção seria causada por uma comunidade de microrganismos. $O$ estudo mostrou que a maioria das bactérias isoladas das lesões foi capaz de aderir às células epiteliais palatinas e que os indivíduos que não usavam próteses apresentavam relativa ausência de bactérias na mucosa palatina quando comparados com os pacientes que usavam próteses. O estudo mostrou que Candida albicans penetrou mais na superfície não polida da prótese (interna) que estava em contato com a mucosa do que na superfície polida e sugeriu o selamento da superfície interna. 
Em 1975, Budtz-Jørgensen et al. avaliaram a mucosa palatina de 465 pacientes usuários de próteses totais maxilares. A prevalência de estomatite protética foi de $65 \%$. Cepas, principalmente no Grupo 1 os quais foram distribuídos em 2 grupos: grupo 1 (291 pacientes) - com Candidíase Atrófica Crônica; grupo 2 (172 pacientes) - com mucosa palatina clinicamente normal. A prevalência de estomatite protética foi de $65 \%$. Em $93 \%$ dos pacientes do grupo 1, foram cultivadas leveduras e entre elas, $77 \%$ eram hifas de Candida albicans. No grupo 2, foram isoladas leveduras em $86 \%$ dos pacientes, sendo $47 \%$ de hifas de Candida albicans. Não houve diferença significante da ocorrência de vários tipos de espécies comparando-se os dois grupos. Por outro lado, a contaminação bacteriana foi maior no grupo 2, revelando que infecções por Candida e higienização deficiente de próteses são muito comuns em idosos.

Estudando a prevalência, características clínicas e possíveis fatores etiológicos da Candidíase Atrófica Crônica, Catalan et al. (1977) examinaram 143 pacientes desdentados totais. Para quantificação dos níveis de biofilme, as superfícies internas das próteses totais superiores foram evidenciadas e o grau de higiene avaliado de acordo com a seguinte escala:

- Higiene boa = $1 / 4$ da superfície evidenciada;

- Higiene Regular = metade da superfície evidenciada;

- Higiene Precária = mais da metade da superfície evidenciada.

A relação entre a higiene das próteses e as condições da mucosa bucal foi significativa, demonstrando que naqueles pacientes onde existia boa manutenção de higiene, as lesões não eram tão frequentes. Quando a higiene foi precária, a frequência das lesões foi maior.

Andrup et al. (1977), estudaram a influência da higienização de próteses totais no tratamento da Candidíase Atrófica Crônica. Os autores avaliaram 33 pacientes acometidos com a patologia. Para avaliação dos níveis de biofilme, foi aplicada a seguinte escala de graduação:

Escore 1: pequena camada de biofilme visível na raspagem com instrumento rombo; 
Escore 2: camada moderada de biofilme na raspagem com instrumento rombo;

Escore 3: Moderado acúmulo de biofilme;

Escore 4: Abundância de biofilme.

Os resultados demonstraram diminuição significativa dos níveis de biofilme após instituição de regime de limpeza.

Backenstose e Wells (1977) estudaram os efeitos de higienizadores de próteses em componentes metálicos de próteses parciais removíveis e totais. Amostras de três metais: níquel-cromo (Ticonium 100®), alumínio (Aluminum®) e aço inoxidável (Elgiloy $\AA)$ foram imersas em: Polident ${ }^{\circledR}$, Efferdent ${ }^{\circledR}$, Mersene $\AA$, Clorox®, Calgon-Clorox®, vinagre $5 \%$, água destilada, água de torneira e foi obtido também um grupo controle (sem imersão). Os metais foram imersos nas soluções por um total de 240 horas, sendo que as soluções foram trocadas a cada 8 horas. As amostras foram analisadas quanto à descoloração (oxidação) e corrosão. Os resultados mostraram que não ocorreu descoloração ou corrosão dos metais imersos em Polident ${ }^{\circledR}$, Efferdent ${ }^{\circledR}$, água destilada ou água de torneira. $\mathrm{O}$ vinagre e o Mersene ${ }^{\circledR}$ causaram alterações superficiais no polimento em algumas áreas. Severa oxidação foi observada nos metais imersos na solução de Clorox®. Concluíram que alvejantes comerciais e soluções de hipoclorito não tamponadas não devem ser usadas em próteses com componentes metálicos.

Lehmann e Arnim (1978) estudaram a capacidade de retenção de encaixes para próteses parciais removíveis. Os autores concluíram que um mínimo de retenção de 5 a $7 \mathrm{~N}$ por encaixe é necessário para que se tenha estabilidade. Segundo os autores, para evitar danos ao tecido mole e ósseo adjacentes, a força de retenção por encaixe não deve exceder $10 \mathrm{~N}$.

Budtz-Jørgensen (1979) classificou os agentes higienizadores em pertencentes ao método mecânico (escovação, pastas e pós, agitação ultra-sônica) e ao químico (peróxidos alcalinos, hipocloritos alcalinos, agentes desinfetantes e enzimas). De acordo com o autor, próteses mal higienizadas são consequência da limpeza mecânica inadequada e da ineficácia da maioria dos produtos comerciais para higienização química das próteses. Também salientou a importância do 
biofilme na saúde da mucosa oral e na saúde geral do paciente, sendo que é obrigação do paciente manter a higienização por meio de cuidados diários e obrigação do dentista instruir e motivar o paciente. $O$ autor salientou que pesquisas devem ser direcionadas para o desenvolvimento de agentes higienizadores que mantenham as próteses isentas de biofilme com um período de imersão diário de 15 a 30 minutos e não afetem a cor e a superfície polida da resina acrílica. $O$ autor recomendou o uso de escova macia e dentifrício com baixo teor abrasivo. Segundo o autor, os higienizadores à base de peróxido podem causar branqueamento nas resinas resilientes e os hipocloritos alcalinos podem manchar e corroer os componentes metálicos da prótese, assim como as soluções higienizadoras à base de ácidos diluídos. Relatou ainda que a imersão diária de próteses totais em gluconato de clorexidina $1 \%$ ou $2 \%$ poderia causar manchamento da resina.

Abere (1979) classificou os higienizadores em agentes químicos para imersão (hipocloritos alcalinos, peróxidos alcalinos, ácidos diluídos e enzimas), ultrassom, escovação e pastas ou abrasivos para próteses. Segundo o autor, a higienização das próteses deve ser realizadas diariamente, com remoção de biofilme e resíduos alimentares, utilizando-se escova específica e sabão neutro. Em regiões da prótese onde não há o alcance da escova, deve-se utilizar uma solução diluída de alvejante, para fricção na superfície da prótese. Soluções de imersão devem ser indicadas para pacientes debilitados ou idosos.

Ito et al. (1980) avaliaram os efeitos do cloreto de cetilpiridínio 0,005 \% na inibição do biofilme dental, por meio da metodologia quantitativa de pesagem de papel. Foram selecionados 68 indivíduos que realizaram dois bochechos diários da solução por 30 segundos, durante um período experimental de quatro semanas. 0 biofilme foi evidenciado com fucsina básica (3\%) em seis superfícies dentais e tais superfícies foram fotografadas com filme para dispositivos. Com a finalidade de estimar a porcentagem da face dental recoberta pelo biofilme, esses dispositivos foram projetados (aumento de 10X), traçados sobre papel e foi realizado o contorno da face interessada e do biofilme. Estes traçados foram recortados e pesados para obtenção da porcentagem da superfície correspondente ao biofilme. A média aritmética dos valores encontrados, em cada uma das seis faces examinadas, forneceu a porcentagem total das áreas recobertas pelo biofilme dental por ocasião de cada visita. Quando a diluição a 0,005\% foi utilizada, houve inibição do biofilme 
dental acompanhada de redução do número de Streptococcus mutans. O cloreto de cetilpiridínio mostrou-se eficaz na prevenção do biofilme dental.

Budtz-Jørgensen et al. (1981) realizaram testes microbiológicos e de microscopia, utilizando fitas adesivas na superfície interna de próteses totais maxilares de 17 indivíduos com mucosa palatina normal. Durante o período de observação (97 dias), os pacientes não higienizaram a superfície interna do aparelho protético. A contagem de leveduras constituiu menos de $1 \%$ do total de microrganismos evidenciados em todos pacientes. $O$ biofilme apresentou predominância de cocos e bastonetes e assemelhou-se ao biofilme maduro da prótese total.

Abelson (1981) avaliou a capacidade de remoção de biofilme de um novo aparelho ultra-sônico (Sonic Scrub®) usado com água comparando com produtos à base de peróxido alcalino: Efferdent ${ }^{\circledR}$ e Polident ${ }^{\circledR}$. Próteses totais de 18 pacientes foram examinadas, limpas e polidas. Os voluntários deixaram de higienizar suas próteses por 3 dias anteriores a cada sessão, perfazendo um total de 3 sessões. Foram atribuídos três critérios de escores: número de dentes apresentando biofilme, índice de biofilme em dentes pré-selecionados e índice de biofilme na base da prótese. Os critérios foram aplicados antes e após a utilização dos produtos de higiene. Os resultados demonstraram superioridade do ultrassom quando comparado com os higienizadores de imersão.

Augsburger e Elahi (1982) estudaram a eficiência de 7 higienizadores químicos de imersão para próteses em um grupo de 110 pacientes usuários de próteses totais. Os produtos utilizados foram: Denalan $\AA$, Mersene $\AA$, Efferdent $\AA$ e em duas versões, Polident®, e duas versões do Kleenite®. As próteses apresentavam biofilme acumulado que foi removido previamente. Os pacientes foram instruídos a não higienizarem suas próteses por 24 horas antes do início do estudo. As próteses foram evidenciadas e examinadas quanto à presença de biofilme e manchas, por meio de atribuição de escores. Foram realizadas as imersões de acordo com as instruções dos fabricantes por 10 minutos, e em seguida foram atribuídos novos escores. Os autores concluíram que o período de imersão utilizado não foi efetivo na remoção do biofilme, sendo recomendados períodos mais longos associados à escovação mecânica. $O$ Mersene ${ }^{\circledR}$ e versão mais recente do 
Kleenite ${ }^{\circledR}$ foram os mais efetivos, tanto para remoção de manchas como para remoção de biofilme.

Kempler et al. (1982) avaliaram a eficácia de várias concentrações de hipoclorito de sódio na remoção de depósitos acumulados em próteses parciais e totais, comparando-as com higienizadores disponíveis no mercado. Foram utilizados os seguintes higienizadores: Polident ${ }^{\circledR}$, Efferdent ${ }^{\circledR}$, Denalan $\AA$, Hipoclorito de sódio $1 \%$ (Clorox®), Hipoclorito de sódio 5\%, Hipoclorito de sódio 25\%, Hipoclorito de sódio $50 \%$ e água de torneira. Foram seguidas as instruções dos fabricantes na higienização com os produtos comerciais. Os grupos de hipoclorito de sódio e o grupo controle foram imersos por 10 minutos. As próteses foram fotografadas e avaliadas por escala de pontos. As soluções de hipoclorito de sódio apresentaram melhor limpeza das próteses, quando comparadas aos produtos comerciais testados. As soluções de hipoclorito de sódio completaram a limpeza dentro de 2 a 3 minutos, mas as próteses permaneceram em solução por 10 minutos. A solução de hipoclorito de sódio $50 \%$ mostrou-se mais efetiva que os agentes de limpeza avaliados.

A especificação sobre higienizadores de prótese do Council on Dental Materials, Instruments and Equipment, 1983, afirma que os produtos comercialmente disponíveis são classificados em pastas abrasivas suaves, agentes oxidantes (hipocloritos, peróxidos e persulfatos), ácidos minerais e enzimas. Afirma também que os testes de eficácia dos higienizadores apresentam resultados variados, pois dependem das condições dos testes e ressalta os riscos dos higienizadores, devendo o paciente observar as precauções quando da ingestão acidental dos produtos ou enxágue inadequado das próteses após as imersões. Segundo a especificação, as instruções e indicações do uso de tais produtos deveriam vir escritas na prescrição dos fabricantes.

Ferran et al. (1984) dividem a higienização dos usuários de prótese total em higiene do aparelho e higiene da mucosa (língua, rebordos alveolares residuais e palato). Os produtos devem ser anti-sépticos e não corrosivos à prótese. Os autores preconizam a escovação do aparelho e da mucosa 3 vezes ao dia e a imersão rotineira do aparelho por no mínimo 10 minutos em anti-sépticos. 
Tarbet et al., em 1984, avaliaram a efetividade de métodos de limpeza na remoção de biofilme de todas as superfícies de próteses totais. Os métodos utilizados foram a imersão em dois agentes químicos de limpeza, Polident® e Efferdent $\AA^{\circledR}$, além da escovação com dentifrício de baixa abrasividade. Os voluntários foram separados aleatoriamente em 3 grupos, referente aos métodos citados anteriormente. Os pacientes retornaram a cada 7 dias, para registro do biofilme. Os resultados mostraram que a escovação com dentifrício de baixa abrasividade provavelmente ocasionou polimento da superfície, resultando em acúmulo inferior de biofilme quando comparado com os demais grupos.

De Paola, Minah e Elias (1984) testaram a atividade antimicrobiana de catorze higienizadores de próteses totais, antissépticos orais e desinfetantes (Kleenite $\AA$, Efferdent $\AA$, Polident $\AA$, Mersene $\AA$, Gluconato de clorexidina a $1 \%$, Clorasséptico®, Listerine $\AA$, Greene Mint $\AA$, Signal $\AA$, Scope $\AA$, Lavoris $\AA$, Cepacol®, Betadine Mouthrinse Gargle ${ }^{\circledR}$ ) em microrganismos patogênicos ( $P$. aeruginosa, Kleibiela pneumoniae, Enterobacter cloacae, E. coli, E. aureus, C. albicans e T. glabrata) isolados de próteses totais de 16 pacientes com câncer. Cinquenta e seis tubos de ensaio contendo meio de cultura Todd Hewith broth (TH) ou Brain Heart Infusion Agar (BHI) foram preparados. Oito destes tubos foram posicionados em cada um dos sete corredores de um aparato. Cada corredor representava o teste de concentração inibitória mínima para um micro-organismo, em cinco diluições de um dos agentes. Assim, alíquotas de $1,5 \mathrm{ml}$ de cada agente testado foram adicionadas nos primeiros tubos de cada corredor e diluições dos agentes (1:2) foram distribuídas sequencialmente até os próximos quatro tubos. Os três tubos restantes serviram como solução teste, meio de cultura puro e cultura controle respectivamente. Aproximadamente $10^{6}$ microrganismos/ $\mathrm{ml}$ foram adicionados em cada tubo contendo os agentes diluídos e no tubo controle. Após incubação, alíquotas dos cinco tubos contendo os agentes diluídos foram semeadas em placas contendo meio de cultura e incubadas. A contagem de unidades formadoras de colônia foi então realizada para determinar a concentração bactericida mínima. Dos agentes higienizadores, 0 Kleenite ${ }^{\circledR}$ foi 0 que apresentou a maior inibição microbiana, sendo seguido pelo Efferdent® e Polident®. O Mersene® não apresentou efeito de inibição sobre nenhum dos microrganismos. Dos agentes antissépticos, o gluconato de clorexidina apresentou os melhores resultados, 
seguido pelo Listerine® e pelo Clorasséptico®. Os melhores agentes com atividade inibitória e bactericida foram o Kleenite $\AA$, Efferdent $\AA$, Polident $\AA$, Listerine $\AA$, Clorasséptico® e Gluconato de Clorexidina a $1 \%$, pois inibiram todos os microrganismos numa diluição 1:4.

Vandenbussche e Swine (1984) encontraram grande número de leveduras na cavidade bucal de portadores de próteses totais, especialmente Candida albicans e Candida glabrata. A Candida albicans foi isolada em $82 \%$ e a Candida glabrata em $48 \%$ dos pacientes com mucosa oral saudável. As 2 espécies estavam associadas em $41 \%$ dos casos.

Abelson (1985) classificou os agentes higienizadores em soluções químicas para imersão (hipocloritos alcalinos e peróxidos alcalinos), agentes abrasivos (pós e pastas), ácidos, ultrassom, antibacterianos e enzimas. O autor realizou uma revisão de literatura sobre biofilme e higienizadores de prótese, modo de ação e eficácia considerando que o produto ideal para higienização das próteses não existe e que deve ser recomendado o uso de mais de um produto para suprir as necessidades da maioria dos pacientes. Concluiu que a escovação com dentifrício apropriado é o método mais eficaz e deve escolhido para pacientes com destreza manual. No caso de próteses acrílicas, a imersão em soluções de hipoclorito é também efetiva para aqueles pacientes que necessitam do emprego de uma solução de imersão, podendo ser utilizado também o peróxido alcalino. $O$ autor salienta ainda que o produto ideal deve ser de fácil manipulação, remover efetivamente os depósitos (orgânicos e inorgânicos), ser bactericida e fungicida, não tóxico aos tecidos bucais e não provocar nenhum dano aos materiais usados na confecção da prótese total.

Segundo a ADA Council on Dental Therapeutics and Council on Prosthetic Services and Dental Laboratory Relations (1985), as soluções de cloro, como o hipoclorito de sódio, foram introduzidas como anti-sépticos em 1835, sendo rotineiramente empregadas como alvejantes caseiros (solução hipoclorito a 5,25\%). Como desinfetante de superfície, a concentração varia de 1 parte de alvejante para 100 partes de água. Em relação aos aparelhos protéticos, é recomendada a imersão do aparelho numa diluição na proporção de 1:10, sendo que o tempo de exposição varia de 10 a 30 minutos. 
Lee et al. (1985) relataram que vários métodos de limpeza de próteses totais têm sido avaliados quanto à sua eficácia e nenhum foi aceito, ainda, como o melhor. Os autores avaliaram métodos populares de limpeza e tentaram desenvolver uma maneira simples de higienização. Pelos resultados obtidos, o método combinado (escovação e higienizador do tipo imersão) foi o método mais efetivo de limpeza, sendo que a escovação deve ser precedida pela imersão. Os estreptococos foram os microrganismos mais comuns no biofilme da prótese e não houve diferença quanto aos microrganismos quando as próteses totais maxilares e mandibulares foram comparadas.

Theilade e Budtz-Jørgensen (1988) estudaram a microbiota de 8 pacientes com Candidíase Atrófica Crônica e encontraram que os estreptcocos constituíam de 17 a $76 \%$ dos microrganismos isolados de cada amostra (identificados como Streptococus mitior, Streptococcus milleri, Streptococcus mutans, Streptococcus salivarius e Streptococcus sanguis). Os estafilococos, (principalmente Staphylococcus aureus) constituíam 2 a $15 \%$. Os bacilos gram-positivos correspondiam a valores entre 5 e $72 \%$, cocos gram-negativos entre 0 e $28 \%$ e bacilos gram-negativos entre 0 e 1,8\%. A contagem de leveduras viáveis variou de 0 a $1,7 \%$. Os resultados mostraram que o biofilme da prótese total indutor de Candidíase Atrófica Crônica tem uma microbiota complexa e variável e é similar à microbiota de pacientes com mucosa oral sadia. A microbiota nos casos de Candidíase Atrófica Crônica apresentou maior porcentagem de leveduras. Segundo os autores, devido à similaridade e à variação individual, a quantificação do biofilme deve ser mais importante que a sua composição. As leveduras são consideradas oportunistas nesta patologia.

Dills et al., em 1988, compararam a efetividade antimicrobiana de dois métodos de higiene (escovação e imersão). Foram realizadas duas avaliações clínicas utilizando um dentifrício abrasivo (Dentu-Cream®) e um produto químico à base de peróxido alcalino para imersão (Efferdent®). Na primeira avaliação, 14 pacientes foram instruídos a não realizar nenhum procedimento de higienização por 48 horas. Ao início do tratamento, foram instruídos a higienizarem suas próteses com um dos seguintes tratamentos: escovação com dentifrício abrasivo para próteses por 30 segundos; imersão em Efferdent ${ }^{\circledR}$ por 12 minutos a $45^{\circ} \mathrm{C}$; escovação associada com imersão e nenhum tratamento. Na segunda avaliação, 16 
pacientes não realizaram nenhum procedimento de limpeza da prótese por 72 horas e realizaram os mesmos tratamentos da primeira etapa. Foram obtidos esfregaços das superfícies internas das próteses e foram realizadas semeaduras em meios de cultura. Os resultados demonstraram superioridade do método de imersão, mesmo quando comparado com o método combinado. De acordo com os resultados, há a necessidade do uso de um agente higienizador químico em adição à escovação com uma pasta adequada para prótese.

Segundo Devlin e Bedi (1988), nota-se que, rotineiramente, na clínica odontológica, pouco tempo de trabalho é destinado às instruções e cuidados em relação ao uso das próteses totais. Um estudo sobre a saúde oral de portadores de próteses totais revelou que, entre os indivíduos que haviam perdido os dentes remanescentes nos últimos 10 anos, somente $39 \%$ relataram ter recebido informações básicas de seus dentistas, como por exemplo, quanto ao uso ou não de suas próteses à noite. Para os conceitos básicos de saúde serem mais efetivamente aplicados, os cirurgiões-dentistas deveria ser claros quanto às instruções transmitidas aos pacientes. Quando o profissional de saúde comunica-se bem, ele aumenta a satisfação de seu paciente com o tratamento. De acordo com os autores, há relação positiva entre a satisfação do paciente e as informações relevantes transmitidas de forma clara na clínica médica. A mesma relação tem sido demonstrada na prática dental, onde os pacientes recebem por escrito as instruções quanto aos retornos e cuidados com as próteses totais. Quando necessário, o cirurgião-dentista deve dispor de maior tempo instruindo os pacientes com princípios básicos de cuidados com as próteses. Essas instruções devem ser passadas aos pacientes de forma oral e por escrito e o cirurgião-dentista deve orientar quanto aos cuidados com as próteses totais durante à noite, quanto à mastigação, salivação, limpeza, limitações e tempo de vida útil dos aparelhos.

Walker, em 1988, estudou a eficiência da adição de solução antimicrobiana dos enxaguatórios bucais e sua efetividade na formação de biofilme e efeito no controle da gengivite. Foram avaliados neste estudo o Listerine $\AA$ e o Periogard $\AA$. $O$ uso destas soluções resultaram em redução significante, após 3 e 6 meses de uso, do número total de anaeróbicos, aeróbios, Streptococcus e Actnomyces. 
Dills et al. (1988) realizaram dois estudos clínicos para testar a eficácia dos métodos de escovação e de imersão na redução do número de microrganismos em próteses parciais e totais. Previamente ao início do primeiro estudo clínico, próteses parciais removíveis de catorze participantes foram escovadas com dentifrício e submetidas à vibração ultrasônica, de modo que todas estivessem em uma condição padrão inicial. Após este procedimento, os pacientes foram orientados a não higienizar suas próteses durante 48 horas prévias ao início do estudo e foram aleatoriamente distribuídos em quatro tratamentos: (1) escovação com dentifrício Dentu-Creme® por 30 segundos; (2) imersão em Efferdent®, por 12 minutos; (3) Associação de 1 e 2; (4) nenhum tratamento. No segundo estudo clínico, dezesseis usuários de próteses totais tiveram suas próteses higienizadas previamente ao início do estudo como citado anteriormente, porém foram orientados a não higienizar suas próteses por um período de 72 horas prévias ao início do estudo. Os participantes foram aleatoriamente distribuídos em quatro tratamentos como descrito no primeiro estudo clínico. Todos os participantes de ambos os estudos, usaram todos os quatro tratamentos de maneira cruzada e randomizada por um período de uma semana cada. Após o uso de cada tratamento, amostras de biofilme da superfície interna das próteses parciais e totais eram colhidas com o auxílio de um swab de algodão, diluídas e semeadas em placas contendo meios de cultura seletivos para: Fusobacterium sp., estreptococos, Veillonela $s p$. e leveduras. Os resultados mostraram que o método de imersão isolado reduziu a maior quantidade de microrganismos, com ação em largo espectro para Fusobacterium sp, estreptococos e Veillonela sp. Os autores concluíram que o uso do método de imersão após a escovação é necessário para a higienização adequada das próteses.

Hoad-Reddick et al., em 1990, investigaram a higienização de próteses em população idosa. Os autores constataram: 1) alto nível de edentulismo; 2) 84,2\% higienizavam as próteses sozinhos; 3) o método de higienização considerado mais satisfatório (escovação e imersão) era utilizado por 40,2\%; 4) 79,1\% das próteses eram higienizadas diariamente; 5) $83,3 \%$ dos pacientes apresentaram-se sem qualquer orientação quanto à higienização; 6) 55,3\% eram usuários de próteses com até 5 anos de uso; 7) 27,9\% das próteses com higiene satisfatória e 15,8\% com higiene deficiente eram imersas regularmente, e em $71,7 \%$ das próteses com higiene satisfatória e em 55,8\% das com higiene insatisfatória foram utilizados 
agentes químicos de limpeza; 8) estomatite protética e queilite angular foram observadas duas vezes mais em pacientes usuários de próteses com higiene insatisfatória. Os autores concluíram que apenas 40\% das próteses encontravam-se devidamente higienizadas e que a maioria dos usuários não foram orientados sobre como realizar correta higienização.

Paranhos, Malachias e Pardini (1991) classificaram os agentes higienizadores em métodos mecânicos (escovação e ultrassom) e químicos (hipocloritos alcalinos, peróxidos alcalinos, ácidos, enzimas e desinfetantes). Segundos os autores, uma limpeza efetiva é obtida com a associação dos dois métodos. O paciente deve ser devidamente instruído pelo cirurgião-dentista quanto ao uso dos agentes higienizadores, sendo de sua responsabilidade a manutenção da higiene por meio de cuidados diários.

Chan et al. (1991) compararam a eficácia de uma solução para imersão (Efferdent®) e um dentifrício para prótese (Dentu-Cream®), na remoção e eliminação de bactérias do biofilme de próteses removíveis. Participaram do estudo dezoito pacientes que não realizaram nenhum procedimento de limpeza por 48 horas e foram distribuídos nos seguintes grupos:: nenhum tratamento; escovação com a pasta por 30 segundos; imersão em água a $45^{\circ} \mathrm{C}$ por 12 minutos e escovação seguida de imersão em Efferdent®, que foram realizados durante duas semanas. Colheitas microbiológicas foram realizadas antes e após cada tratamento. Os resultados mostraram que a imersão foi tão efetiva quanto o tratamento combinado na remoção e eliminação de fusobactérias. O tratamento combinado foi mais efetivo na remoção de bactérias facultativas e anaeróbias. O tratamento combinado removeu resíduos alimentares, sendo, de acordo com os autores, o método mais indicado para higienização de próteses totais removíveis.

Jagger e Harrison (1995) avaliaram quais os métodos de higienização mais comum entre os usuários de próteses totais e parciais removíveis. Cem pacientes participaram da pesquisa. Os resultados mostraram que $46 \%$ dos pacientes relataram que nunca haviam recebido orientação sobre como higienizar as próteses. O peróxido alcalino foi o agente químico de higienização mais comumente utilizado. Os autores afirmaram que a escovação é um método eficiente de higienização e que exige, porém, destreza manual. Os autores sugeriram, ainda, que as próteses com 
estrutura metálica podem ser higienizadas pela imersão em solução de peróxido alcalino associado a enzimas proteolíticas.

Webb et al. (1995), após revisão de literatura sobre o efeito do hipoclorito de sódio no potencial patogênico das espécies de Candida, concluíram que o hipoclorito de sódio pode afetar a habilidade das leveduras em se manter como parte da microbiota oral, já que há diminuição destes microrganismos na superfície da prótese total. Os autores sugeriram que o hipoclorito de sódio pode funcionar como efetivo agente antifúngico, quando usado como higienizador de próteses dentárias, em casos de estomatite protética.

Unlü et al. (1996) avaliaram os efeitos de quatro diferentes agentes higienizadores (Polident $\AA$, Efferdent $\AA$, Blend-A-Dent $\AA$ e Corega Tabs $\AA$ ) em seis tipos de resina acrílica. Os autores relatam ter seguido as instruções dos fabricantes no preparo das soluções, imergindo os discos de resina, por ciclos de 8 horas em um total de 240 horas. As soluções eram trocadas a cada intervalo de 8 horas. Concluíram que a Polident ${ }^{\circledR}$ apresentou o menor efeito branqueador em resinas acrílicas e a Corega Tabs®, o maior.

Rigdon, em 1996, discutiu as vantagens e desvantagens das próteses retidas por implantes, salientando que a força de retenção proporcionada pelos sistemas de encaixe para overdentures implanto-retidas é de fundamental importância para o sucesso do tratamento reabilitador, para a satisfação do paciente no que diz respeito a estabilidade da prótese durante a função, estética e fonética. As maiores vantagens deste sistema são as de permitirem movimentação da prótese, distribuírem as forças mastigatórias entre as estruturas de suporte e diminuírem a carga sobre os pilares na ordem de 75 a $85 \%$.

Kulak et al., em 1997, avaliaram os efeitos da escovação e das soluções químicas hipoclorito de sódio a $5 \%$, Savlon® (clorexidina a 1\%) e Ipanol® (enxaguatório bucal), além dos agentes químicos efervescentes Corega Tabs®, Dentipur ${ }^{\circledR}$ e Fittydent ${ }^{\circledR}$ na superfície de próteses totais. As próteses foram imersas nas soluções no período noturno. Observou-se que todas as soluções reduziram a porcentagem de área da amostra coberta por biofilme quando comparadas com o controle (escovação). Os autores sugeriram que a limpeza mecânica isoladamente não é efetiva na remoção total de microrganismos. 
Allen, McMillan e Smith, em 1997, realizaram uma análise retrospectiva com 60 pacientes usuários de próteses retidas por implantes de um hospital dentário britânico com o intuito de avaliarem a prevalência de complicações e condições de higienização. Foram avaliadas 66 próteses, que geraram 236 intervenções no período de 6 anos. As complicações protéticas mais comuns incluíam o desgaste dos componentes, troca de clipes e reparo nas próteses antagonistas. O controle de biofilme foi insatisfatório em quase metade dos pacientes avaliados, o que remete à necessidade de instruções de higienização mais claras e incisivas para o paciente, além de retornos programados para cuidados profissionais. Os autores concluíram que a necessidade de manutenção é frequente, principalmente no primeiro ano de uso.

Mähonen,Virtanen e Larmas (1998) afirmaram que a introdução de uma prótese parcial removível na cavidade bucal modifica o ambiente ecológico. Esta mudança pode ser quantitativa (aumento da quantidade total de microrganismos) ou qualitativa (aumento de determinado microrganismo da microbiota bucal). Isto pode expor o paciente a maior risco de sofrer danos nos tecidos, entre eles a inflamação da mucosa bucal.

Segundo Nikawa et al. (1998) existem trabalhos que indicam que há possibilidade do biofilme da prótese total contendo espécies de Candida ser responsável pelo aparecimento de cáries, raízes cariadas e periodontite de pilares, dentes adjacentes ou antagônicos às próteses totais unitárias ou parciais. Deste modo, os autores relataram que o controle efetivo do biofilme da prótese é essencial, e, embora haja muitas avaliações da eficácia de higienizadores de próteses totais, pouca atenção tem sido dada aos materiais e métodos usados para avaliar estes agentes.

Lacerda (1998) revisou os recursos utilizados para a limpeza das próteses totais e classificou os agentes higienizadores em limpadores químicos (hipoclorito de sódio, dentifrícios, peróxidos, bicarbonato de sódio e perborato de sódio) e mecânicos (escovas e ultrassom). Sugeriu a personalização das orientações de higienização, dimensionando-as de acordo com o grau de instrução dos pacientes.

Epstein et al., em 1999, compararam a retenção de seis encaixes para overdentures (AcessPost, ERA branco e cinza, Flexi-Overdentures, O-SO e ZAAG 
após ensaios mecânicos de fadiga por inserção e remoção (ciclagem). Cada encaixe foi cimentado com cimento fosfato de zinco em uma raiz de um dente monorradicular, e o conjunto incluído em resina acrílica, resultando em 60 amostras. Utilizou-se um dispositivo chamado Shimpo Force Gauge para as medidas de retenção, que foram foram obtidas por meio de tração manual após 10 ciclos, e depois a cada 50, até serem totalizados 2000 ciclos. As amostras que apresentavam maior retenção na primeira leitura foram as que demonstraram maior diminuição, ao contrário das que apresentaram retenção menor no primeiro momento. Ao final dos ciclos não houve diferença entre os sistemas. Os autores concluíram que quanto mais rígido e maior a força de retenção oferecida pelo encaixe, mais rapidamente haverá diminuição da sua retentividade. Wichmann e Kuntze (1999) avaliaram o desgaste de encaixes de precisão confeccionados de metal e plástico. Os encaixes foram submetidos a 10000 ciclos de inserção e remoção, na presença de saliva artificial a $37^{\circ} \mathrm{C}$. Os encaixes com componentes metálicos apresentaram perda de retenção de aproximadamente $60 \%$ durante os primeiros 1000 ciclos, já os de plástico perderam de 6 a $8 \%$ da retenção, ocorrendo em um caso, aumento de $20 \%$ da retenção após os ciclos.

Nikawa et al. (1999) realizaram revisão de literatura sobre métodos de higiene empregados e sua eficácia. Afirmaram que os diversos higienizadores de prótese não demonstraram mesma eficácia in vivo e in vitro. Enfatizaram a necessidade de padronização da metodologia, realização de ensaios in vitro e in vivo e avaliação qualitativa e quantitativa do biofilme presente na prótese. Ainda, segundo os autores, as soluções químicas do tipo imersão para próteses totais comercializadas podem ser classificadas de acordo com seu modo de ação ou de acordo com seus componentes de limpeza: hipocloritos, peróxidos, peróxidos neutros com enzimas, enzimas, ácidos, drogas e enxaguatórios bucais para próteses totais. Os resultados do estudo mostraram que a escovação isolada é insuficiente para o controle do biofilme e que a associação de higienizadores químicos à escovação é indispensável para os cuidados caseiros diários.

Sesma et al. (1999) investigaram a eficácia de 3 métodos de higienização de próteses parciais removíveis por meio da análise em microscópio eletrônico de varredura. Foram avaliados três métodos em 10 pacientes usuários de PPRs: escovação com dentifrício; escovas de dentes com dentifrício associada à imersão 
em produto químico manipulado a base de perborato de sódio (limpador efervescente, Fórmula e Ação®) e escovação com dentifrício associada à aplicação de digluconato de clorexidina a $2 \%$ Os pacientes utilizaram cada método por uma semana. Após 7 dias, amostras foram obtidas da região interna da sela das próteses para análise em microscópio eletrônico de varredura. Observou-se que o uso do método mecânico associado à imersão da prótese no produto químico efervescente promoveu melhor higienização em relação ao uso do método mecânico. Mas a aplicação da clorexidina a $2 \%$ na parte interna da sela da prótese associada ao método mecânico foi melhor que os métodos anteriores. Apesar disto, concluiuram que nenhum dos métodos conseguiu eliminar totalmente o biofilme da superfície das próteses.

Paranhos et al. (2000) avaliaram a capacidade de remoção de biofilme e a ação antimicrobiana de umdentifrício. Os autores avaliaram a efetividade deste produto em fungos e nos estreptococos em 120 próteses totais acrílicas. Os pacientes foram orientados a realizar a higienização e registar por meio de questionário suas impressões. O dentifricio foi bem aceito pelos pacientes e foi efetivo no controle dos patógenos. Os microrganismos isolados com mais frequência foi o C. albicans, C. tropicalis e C. glabrata. Desta forma, o produto proposto foi adequado para a higienzação diária de próteses totais.

Sheen et al., em 2000, avaliaram a efetividade de uma pastilha efervescente não comercial à base de peróxido alcalino no controle do biofilme de próteses totais. Além disso, os autores analisaram o método de quantificação do biofilme por meio de fotografias digitais associadas à inspeção visual. Trinta e cinco pacientes foram divididos em dois grupos: água ou imersão na pastilha. $O$ tratamento foi realizado por 14 dias e o biofilme foi mensurado no $2^{\circ}$ e $14^{\circ}$ dias. O produto reduziu em $51 \%$ a quantidade de biofilme no $2^{\circ}$ dia e $47 \%$ no $14^{\circ}$ dia quando avaliados por meio das imagens e esta porcentagem coincidiu com a análise visual.

Shay, em 2000, classificou os métodos de higiene em mecânicos (escovação e uso de aparelho ultrassônico), químicos (solução doméstica, exposição ao oxigênio por meio de secagem e radiação por microondas) e combinado. A solução doméstica mais comumente utilizada era o alvejante diluído em água (hipoclorito de sódia na proporção 1:10). O autor concluiu que somente a escovação não é efetiva 
no controle de biofilme e que o efervescente comercial constitui um método mais efetivo de limpeza.

Walber e Rados (2000) realizaram um estudo comparativo de tratamento da estomatite protética por reembasamento ou substituição das próteses totais. Foram selecionados 30 pacientes, que foram divididos em dois grupos experimentais: dezoito pacientes tiveram suas próteses maxilares substituídas e os outros doze tiveram suas próteses reembasadas. Foi solicitado aos pacientes que removessem suas próteses à noite e as imergissem em solução de hipoclorito de sódio $2,5 \%$ diluído em um copo d'água. Os pacientes foram monitorados por 8 semanas e foi constatada melhora em $90 \%$ no prazo de 4 semanas para ambos os grupos. Os autores concluíram que os dois tratamentos se mostraram eficientes no controle da estomatite protética.

Ship et al., em 2002, avaliaram a xerostomia em idosos e seu impacto na proliferação de microrganismos quando há próteses instaladas na cavidade oral. Os autores evidenciaram em seu estudo a importância da saliva na preservação na saúde oral e denominaram as patologias associadas com a disfunção salivar: medicação, radioterapia na região de cabeça e pescoço e a síndrome de Sjögren. O tratamento consiste na reposição dos fluidos por meio de salivas artificiais e estimulação das glândulas remanescentes.

Torres et al., em 2002, avaliaram a relação entre o fluxo salivar e a contagem de Candida albicans em pacientes com xerostomia. A sialometria e a contagem de unidades formadoras de colônia foram realizadas em 112 pacientes. A salivação foi estimulada e inoculada em placa, onde foram contados os microrganismos. Os resultados demonstraram prevalência inversamente proporcional de Candida albicans em relação ao fluxo salivar. A sialometria em homens apresentou maiores valores que em mulheres, entretanto não houve correlação entre a quantidade de colônias e o gênero ou idade. Houve $28 \%$ de colonização mista, ou seja, presença de outros microrganismos além da Candida albicans: Candida parapsilosis, Candida topicalis e Candida krusei.

Kulak-Oskan, Kazazoglu e Arikan (2002) avaliaram os hábitos de higiene oral, limpeza de próteses totais e presença de estomatite protética em idosos. Setenta próteses totais foram avaliadas clinicamente e microbiologicamente. Os resultados 
demonstraram que $48,6 \%$ das próteses apresentavam higienização deficiente e somente 15,7\% apresentavam higienização considerada excelente. Em 38,6\% das próteses havia a presença de Candida.

Jagger et al., em 2002, avaliaram a efetividade de higienizadores de próteses (produtos comerciais à base de hipoclorito alcalino e um pó higienizador Boots Denture) na remoção de manchas de chá e clorexidina. Foi usado um espectrofotômetro para avaliar a quantidade de manchas antes e depois do uso dos produtos, tanto em resina acrílica polida quanto rugosa. Os resultados demonstraram a capacidade de remoção de manchas pelos produtos que continham hipoclorito na sua composição, causando inclusive branqueamento da resina. $\mathrm{Na}$ resina rugosa, as manchas não foram removidas na mesma intensidade que na polida.

Bonachela et al., em 2003, avaliaram a perda de retenção de quatro tipos de encaixes (o'ring, O-SO, ERA branco e ERA cinza) usados em overdentures, em função do tempo de uso. Foram simulados ciclos de inserção e remoção de 6 meses, 1, 2, 3, 4 e 5 anos, utilizando a máquina universal de ensaios. Foram tomadas as medidas de tração antes e após os ensaios. Todos os sistemas perderam a retenção durante o experimento. Os sistemas ERA, principalmente o cinza, demonstraram retenção superior aos outros sistemas.

van Kampen et al. (2003) avaliaram a retenção e necessidade de manutenção de overdentures mandibulares retidas por barra/clipe, o'ring e magnetos após 3 meses em função. Dezoite pacientes receberam 2 implantes mandibulares e foram dividos nas 3 modalidades de overdentures. Não foram encontradas diferenças de retenção quando avaliados os tempos inicial e após 3 meses para todos os tratamentos. Foram observados alguns problemas de manutenção, em maior escala para os magnetos, seguidos pelos o'rings, onde 4 anéis precisaram ser susbtituídos, e não houve problema no período avaliado para os do tipo barra/clipe.

Walton, em 2003, comparou dois tipos de encaixes para overdentures (barra/clipe e o'ring) após 3 anos de uso. Cem pacientes receberam próteses totais superiores e uma overdenture mandibular, entretanto permaneceram no grupo de estudo apenas 87 pacientes. O autor avaliou que o o'ring exigiu mais manutenção que o de barra/clipe, o que incluía reaparos maiores como troca das cápsulas de 
retenção. Desta forma, segundo os achados clínicos, o autor sugere que a barra/clipe é mais indicada para este tipo de tratamento.

Barbeau et al., em 2003, avaliaram a associação de Candida albicans com estomatite protética. Na classificação dos autores, houve alta prevalência de cepas e colonização de microrganismos, principalmente em pacientes com inflamação mais severa. Os autores constataram que pacientes que não retiravam as próteses para dormir e fumantes apresentavam maior grau de inflamação. Os autores sugeriram que o processo inflamatório da estomatite favorecia a colonização de Candida.

Keyf e Güngör (2003) avaliaram os efeitos das pastilhas efervescentes de higienização e clareadores sobre as mudanças superficiais e de refletância em uma liga metálica de cobalto-cromo utilizada para PPR por um período de 30 dias. Foram confeccionados corpos-de-prova metálicos $(10 \times 10 \times 1 \mathrm{~mm})$ que foram incluídos posteriormente em resina acrílica. Dezenove corpos-de-prova foram divididos em três grupos: água de torneira $(n=6)$, Corega Tabs ${ }^{\circledR}$ (higienizador à base de peróxido, $\mathrm{n}=6$ ) e Axion® (clareador à base de hipoclorito de sódio, $n=7$ ). A massa dos corposde-prova foi mensurada e os espécimes foram imersos, sendo as soluções preparadas conforme instruções dos fabricantes $(200 \mathrm{ml})$ e trocadas de 12 em 12 horas. Foram realizadas leituras de alteração de massa e análise superficial por meio de espectrofotômetro. Além disto, foram obtidas fotomicrografias por meio de um microscópio de Vickers. Observaram que as soluções à base de peróxido e hipoclorito de sódio apresentaram efeitos na superfície da liga de Co-Cr, como descoloração (perda de brilho) e manchamento, porém a massa dos corpos-deprova foi mantida.

Nikawa et al, em 2003, estudaram a formação de biofilme de Candida albicans em superfícies de materiais deterioradas por higienizadores de próteses em imersões de 180 dias. Foram utilizados 5 higienizadores (Steradent $\AA$, Correct $\AA$, Polident ${ }^{\circledR}$, Pika DCE $\AA$ e Clean Soft $\left.{ }^{\circledR}\right)$ e 8 tipos de materiais para reembasamento de próteses (Bio Resin $\AA$, Soften $\AA$, Nissin Soft Reverse $\AA$, Mollosil $\AA$, Evatouch $\AA$, Tokuyama®, GC® e Molloplast $\mathrm{B} \AA$ ). Os materiais foram imersos nos higienizadores por 8 horas em temperatura ambiente e, posteriormente, foram mantidos em água destilada por 24 horas a $37^{\circ} \mathrm{C}$. As soluções de imersão foram preparadas para cada um dos 180 dias. $\mathrm{O}$ pH do meio foi mensurado e observou-se diminuição para todas 
as situações experimentais. A formação de biofilme foi dependente dos materiais. $\mathrm{O}$ Evatouch $\AA$ apresentou maior rugosidade e a resina e $0 \mathrm{GC} \circledast$ apresentaram os menores valores. Não houve correlação entre rugosidade e formação de biofilme.

Botega et al., em 2004, avaliaram a força de retenção e resistência à fadiga de dois sistemas de encaixes o'ring e barra/clipe da Conexão Sistemas de Prótese e Lifecore. Os espécimes $(n=5)$ foram submetidos a 5500 ciclos de inserção e remoção $(f=0.8 \mathrm{~Hz}$ ), imersos em saliva artificial. A força de retenção foi medida antes dos ciclos, após 3000 e ao final de 5500 ciclos (célula de carga de $1 \mathrm{kN}$ e velocidade de $1 \mathrm{~mm} \mathrm{~min}^{-1}$ ). Os resultados demonstraram que o conjunto barra/clipe da Conexão apresentaram maior retenção que os da Lifecore $(44,61 \mathrm{~N}$ e $18,44 \mathrm{~N}$ respectivamente), entretanto os o'rings da Lifecore apresentaram maior retenção que os da Conexão (19,75 N e 13,91 N, respectivamente). Todos os sistemas apresentaram retenção satisfatória antes e após os ensaios. Os autores concluíram que 0 uso por 5 anos dos conjuntos de overdentures não fizeram com que a retenção diminuísse e também não houve fratura dos componentes.

Naert, Alsaad e Quirynen, em 2004, avaliaram clinicamente, após 10 anos, 36 pacientes que receberam overdentures retidas por barra/clipe, o'rings e magnetos sobre dois implantes mandibulares. Os resultados demonstraram que os o'rings apresentaram maior força de retenção, seguidos pelos barra/clipes e magnetos. As maiores complicações encontradas no grupo o'ring, foram necessidade de aperto no pilar e troca das cápsulas; no clipe foi o desgaste e necessidade de ativação e no magneto, a corrosão. Com relação aos magnetos, os pacientes relataram maior instabilidade e falta de conforto durante a mastigação, entretanto, com os o'rings, relataram maior conforto e segurança.

Em 2004, Garcia et al. avaliaram os efeitos de higienizador de prótese à base de perborato de sódio e água de torneira (controle) na rugosidade superficial e dureza da resina acrílica polimerizada por microondas e de ligas de cobalto-cromo e Ti-6Al-4V. Os autores relataram que as ligas de cobalto-cromo podem apresentar corrosão ou manchamento como resultado do contato superficial com cloro ou oxigênio presentes em alguns agentes higienizadores comerciais, obrigando os usuários de prótese a fazerem uma seleção prudente quanto aos produtos a serem utilizados na higienização diária. Foram obtidos corpos-de-prova de forma retangular 
(30 x $10 \times 2 \mathrm{~mm})$ de liga metálica inseridos em discos de resina acrílica (30 x $4 \mathrm{~mm})$. Os grupos experimentais utilizados foram a pastilha efervescente Polident $\circledast$ e água de torneira (controle), variando a liga $(n=8)$. As soluções foram preparadas conforme instruções do fabricante ( $200 \mathrm{ml}$ a $37^{\circ} \mathrm{C}$ por 5 minutos). Após imersão, os espécimes foram lavados em água destilada por 10 segundos e armazenados em saliva artificial por 5 horas. As imersões foram preparadas e trocadas diariamente. Os ensaios de dureza Knoop e de rugosidade superficial foram realizados. Observaram formação de uma película tanto na superfície da resina acrílica quanto das ligas metálicas. Concluíram que esta película poderia influenciar no aumento tanto da dureza quanto da rugosidade dos materiais. A Polident® foi capaz de remover essa película, sem afetar a dureza superficial e rugosidade tanto da resina como da liga metálica.

Barnabé et al. (2004) realizaram um estudo com o objetivo de avaliar a eficácia do hipoclorito de sódio $(0,05 \%)$ e do sabão de coco na redução das espécies: Streptococcus mutans (SGM) e Candida albicans e na redução de estomatite em usuários de prótese total superior. Sessenta pacientes com faixa etária média de 60 anos participaram do estudo. Os participantes foram distribuídos em 2 grupos: Grupo 1: 30 pacientes; escovação da prótese com sabão de coco seguido por imersão em solução de água filtrada $(200 \mathrm{ml})$ e água destilada (10 ml placebo), por 10 minutos. Grupo 2: 30 pacientes; escovação da prótese com sabão de coco seguida por imersão em solução de hipoclorito de sódio a 0,05\% por 10 minutos. Foram realizadas duas coletas do biofilme presente nas próteses, uma antes e uma após 15 dias do início do tratamento. Para a obtenção das coletas, cada prótese foi escovada com uma escova dental esterilizada e $10 \mathrm{ml}$ de solução salina por 1 minuto; essa solução foi transferida com uma pipeta a um tubo esterilizado para análise. Além da coleta, o estudo realizou a análise clínica da qualidade da mucosa (classificação de Newton) e da higienização das próteses, também antes e 15 dias após o início do tratamento. Os fungos foram isolados e incubados por $72 \mathrm{~h}$ a $37^{\circ} \mathrm{C}$. O isolamento dos Streptococcus mutans foi feito com cultura com diluições seriadas e com meio inibidor de crescimento de fungos. A escovação com sabão de coco associada ao uso do hipoclorito de sódio a 0,05\% foi efetiva no controle de biofilme das próteses, reduziu significativamente os sinais clínicos de Estomatite Protética, promoveu leve redução do número de 
Streptococcus mutans e não apresentou efeito sobre o número de Candida albicans.Os autores justificaram a não redução da Cândida por ela pertencer a microbiota natural da cavidade oral. Além disso, eles supuseram que os tratamentos controlaram a patogenicidade da Cândida, pois houve redução do índice de Newton (não foram apresentados dados estatísticos).

Rocha et al., em 2004, verificaram que nas contagens de ufc/mL após o bochecho, tanto o Periogard $(\AA$ quanto $\circ$ Cepacol $\circledast$ apresentaram resultados significantes. In vitro, os dois antissépticos utilizados após a higienização mecânica foram eficazes na redução da microbiota da saliva, observando-se atividade menor do Cepaco|® em relação aos bastonetes gram negativos. Segundo os autores, os dois antissépticos testados são eficazes contra os microrganismos bucais isolados nas concentrações encontradas nas formulações comercialmente disponíveis. Ressaltaram que a maneira ideal de realizar boa higiene bucal é por meio de profilaxia mecânica, envolvendo escovação e uso de fio dental. Além disso, em vista das condições microbiológicas (alterações do número e espécies microbianas) apresentadas, faz-se necessário o uso de substâncias químicas complementares, como os dois antissépticos citados.

Lamfon et al., (2005) avaliaram a formação de biofilme de Candida albicansem esmalte, dentina e resina acrílica de diferentes rugosidades. Os materiais foram colonizados e, posteriormente ao crescimento, o biofilme era desorganizado e as colônias contabilizadas. No esmalte havia mais microrganismos que na dentina ou resina. A maior parte de colônias foi encontrada no tempo de 6 horas. Quando avaliadas as resinas em diferentes rugosidades, foi observado que quanto mais rugosa a superfície, havia mais contaminação. A rugosidade afeta a formação inicial da Candida albicans, o que favorece seu desenvolvimento e estrutura.

Sato et al., em 2005, avaliaram a resistência à flexão e alteração de cor de resinas acrílicas termopolimerizáveis (Lucitone $550 \AA$, QC- $20 \circledast$ e Triplex®) após imersão em soluções higienizadoras de próteses totais (Bony Plus Express ${ }^{\circledR}$, Corega Tabs ${ }^{\circledR}$ e Efferdent $\AA$ ) por 15 minutos e 8 horas simulando 30 dias de uso. $\mathrm{O}$ teste de flexão foi realizado em máquina de ensaios mecânicos e a análise visual da estabilidade de cor foi realizada por meio de fotografias. A inspeção visual não 
demonstrou qualquer alteração de cor. Concluíram que os agentes higienizadores, quando utilizados de acordo com as instruções dos fabricantes, não afetaram a resistência à flexão e não causaram alterações de cor nas resinas acrílicas.

Berger et al. (2006) avaliaram a rugosidade superficial de resinas acrílicas para base de próteses após processamento e polimento. Foram utilizados 4 tipos de resina acrílica (termopolimerizável, autopolimerizável, polimerizável por microondas e injetável) e 4 tipos de polimento (convencional, Axis, Brasseler e Shofu) foram avaliados. Foram encontradas diferenças estatisticamente significantes entre as resinas antes do polimento: as resinas injetada e termopolimerizável apresentaram menor rugosidade que a autopolimerizável. Os valores da resina polimerizada por microondas não diferiram dos valores das demais resinas. Após o polimento convencional com pedra-pomes e uma pasta diamantadaas resinas injetadas e de microondas apresentaram menores valores de rugosidade que a autopolimerizável. A resina termopolimerizável não apresentou diferença das demais. Após polimento com os kits comerciais, as resinas injetada, de microondas e termopolimerizável apresentaram menor rugosidade que a autopolimerizável. Não houve diferença entre os três sistemas de polimento. Houve diferença estatística entre os métodos convencional e os kits comerciais, tendo o primeiro apresentado menores valores de rugosidade. Os autores sugeriram a utilização do polimento convencional com pedra-pomes e compósitos, salientando a necessidade de se obter menor porosidade para evitar a colonização de microrganismos patogênicos.

Berger e Ewoldsen, em 2006, estudaram o controle de biofilme em próteses totais. Os autores afirmaram haver desorganização do biofilme por meio da escovação, porém ressaltaram a necessidade de associação com um método químico de higienização tanto para remover micro-colônias sobreviventes à desorganização como para atingir os microrganismos acumulados nas porosidades dos materiais da prótese. Os autores sugeriram a diluição de hipoclorito de sódio em água na proporção de 1:10.

Lovato-Silva et al., em 2006, realizaram levantamento do grau de instruções e dos materiais e métodos de higiene utilizados por idosos usuários de próteses totais. Foram entrevistados 98 pacientes usuários de próteses totais no ano de 1989 e 100 pacientes no ano de 2004. Em 1989, 93,87\% dos pacientes relataram utilizar escova 
e dentifrício para higienização e em 2004, 95\% relataram utilizar o mesmo método. Quanto ao grau de instrução, mais de 80\% dos pacientes de 1989 não receberam orientações do cirurgião-dentista. Em 2004, percebeu-se melhora, com 52\% relatando não terem recebido orientação quanto à higienização e $77 \%$ tendo recebido informações quanto à necessidade de retorno periódico ao cirurgiãodentista. Por meio deste estudo, os autores verificaram que o método mais utilizado para higienização é o mecânico. Embora o grau de instrução tenha melhorado, a higienização encontrada foi precária, evidenciando a necessidade de maior atenção a esses pacientes.

Paranhos et al. (2007) avaliaram os efeitos dos métodos mecânicos de higienização de próteses totais e químicos no acúmulo de biofilme. Os autores quantificaram o biofilme após os seguintes tratamentos: imersão em água, imersão em solução de peróxido alcalino, escovação com dentifrício para próteses, combinação de escovação e imersão em solução de peróxido alcalino. Concluíram que a quantidade de biofilme foi maior no grupo da imersão em água quando comparado com os demais grupos. Ainda, a remoção foi mais efetiva com o uso de escovação que a imersão em solução de peróxido alcalino. Mas, os melhores resultados foram encontrados com a combinação de ambos.

Varghese et al., em 2007, avaliaram o efeito de soluções higienizadoras (Polident Regular, Polident Overnight, Efferdent, hipoclorito de sódio 5,25\% na diluição de 1:10 por 15 minutos/dia, hipoclorito de sódio 5,25\% na diluição de 1:10 por 8 horas/dia, água e grupo sem solução) na retenção do clipe amarelo de Hader por 6 meses de uso. Os resultados demonstraram que as soluções afetaram a retentividade dos clipes. $O$ hipoclorito por 15 minutos causou aumento na retenção do conjunto, sendo a única solução a diferir significantemente para as demais. Não houve diferença estatística entre os demais grupos, sendo todas as soluções similares aos grupos controles água e seco. Lessa et al., em 2007, estudaram a eficácia de agentes antissépticos (Periogard $($ e Cepacol®) na forma de spray, no controle de biofilme formado principalmente por Streptococcus mutans em aparelhos ortodônticos removíveis. Concluíram que tanto o Cepacol $($ quanto o Periogard $(\AA$ reduziram a formação de biofilme e ambas as soluções foram diferentes estatisticamente quando comparadas com o grupo controle (água de torneira). 
Porém, o Periogard® mostrou maior eficácia (100\%) quando comparado com Cepacolß $(58,9 \%)$.

Watanabe et al., em 2008, realizaram estudos comparativos da eficiência de diferentes diluições dos enxaguatórios à base de cloreto de cetilpiridínio na eliminação de Staphylococcus aureus. Concluíram que os enxaguatórios à base de cloreto de cetilpiridínio demonstraram ação antimicrobiana e a adição de outras substâncias como própolis, malva, eucaliptol, romã e juá, potencializam o efeito antimicrobiano.

Buergers et al., em 2008, avaliaram 10 métodos de desinfecção de próteses e sua eficácia em reduzir a quantidade de Candida albicans em reembasadores resilientes. Obtiveram espécimes circulares confeccionados com reembasador (Mucopren $\mathrm{E} \AA$ ) que, posteriormente, foram incubados com C. albicans e submetidos aos procedimentos de desinfecção com imersão em 6 soluções (hipoclorito de sódio $1 \%$, peróxido de hidrogênio, glutaraldeído, vinagre, Listerine $\AA$, Plax®). Foram urtilizados 2 métodos de microondas ( $800 \mathrm{~W}, 6$ minutos em água e a seco), uma pastilha efervescente (Blend-a-Dent®) e armazenamento overnight a seco. Apenas as imersões em hipoclorito de sódio 1\%, desinfecção por irradiação em microondas com água e pastilha Blend-a-Dent® foram eficientes na eliminação das colônias de Candida.

Pinto et al, em 2008, estudaram os efeitos do vinagre como agente antimicrobiano para controle das espécies de Candida. Foi realizado um estudo clínico com 55 pacientes usuários de próteses totais maxilares. Os pacientes foram instruídos a imergir suas próteses em solução de vinagre a $10 \%$, por um período overnight, por 45 dias. Amostras de saliva foram colhidas antes e após o período experimental para identificação e contagem de cepas. Os resultados demonstraram que cepas de Candida estavam presentes em 87,3\% das amostras de saliva antes do tratamento. Verificou-se redução significativa na contagem (cfu/mL) de cepas após o tratamento. Os autores concluíram que há correlação positiva entre a presença de Candida e a manifestação clínica de estomatite protética.

Karabuda, Yaltirik e Bayraktar, em 2008, compararam clinicamente as complicações de diferentes sistemas de overdentures (2 ou 4 implantes unidos por uma barra, ou a mesma situação com pilares o'rings). Vinte e seis pacientes foram 
incluídos no estudo e as seguintes complicações foram observadas: fratura da barra, fratura da prótese, problemas de higienização, desaperto do pilar, desgaste do anel e necessidade de substituição, além de fratura do clipe. A média de tempo de instalação das barras/clipes foi de 49 meses e para os órings foi de 23 meses. No total foram verificadas 20 compicações, sem predominânca específica para um dos grupos. Apesar disto, os autores sugeriram que os dois métodos são confiáveis.

Bayer et al., em 2009, compararam quatro sistemas de encaixe (SG: cápsula em ouro da Straumann, ST: cápsula em titânio da Straumann, IB: cápsula plástica da UNOR e IMZ: cápsula de ouro da Dentsply) quanto à força de retenção. Dez amostras de cada grupo foram submetidas a 10000 ciclos de inserção e remoção. Todos os encaixes demonstraram desgaste, que levaram à perda de retenção depois da leitura inicial. As cápsulas plásticas e de ouro apresentaram melhor comportamento quando comparadas às de titânio, o que pode sugeir que os primeiros são mais indicados para esta opção reabilitadora. Os autores também apontaram a necessidade dos encaixes serem ajustáveis, para compensar estas alterações de retenção ao longo do tempo.

Ribeiro et al., em 2009, realizaram um estudo longitudinal de 12 meses para avaliar o efeito da educação de higiene oral e motivação em usuários de próteses parciais removíveis. Cinqüenta e três pacientes parcialmente edêntulos participaram do estudo. Em uma consulta preliminar, a presença ou ausência de biofilme e sangramento gengival por sondagem foram mensurados em todas as superfícies dos dentes. Os pacientes foram divididos em três grupos: grupo 1 - os pacientes foram orientados a seguir sua higienização de rotina; grupo 2 - foram dadas instruções verbais e um manual educativo sem imagens e grupo 3 - um guia de higienização foi entregue usando a combinação de instruções verbais e um manual auto-didático. Para avaliar o efeito dos diferentes tipos de instrução, a presença ou ausência de biofilme e sangramento gengival por sondagem foram reavaliados aos 7, 15 e 30 dias, 3, 6 e 12 meses após instalação. Foram avaliadas também as condições de higienização das próteses nos mesmos períodos. Os resultados demonstraram que houve diferença estatisticamente significante entre a consulta preliminar e os outros períodos e também entre os grupos 1 e 3 , tendo o grupo 3 apresentado higienização mais efetiva. 
Ferreira et al. (2009) avaliaram o efeito de higienizadores de próteses na aderência de C. albicans e C.glabrata em condicionadores de tecido. Após a contaminação com as leveduras, os espécimes foram tratados com os seguintes higienizadores: (1) perborato de sódio Polident ${ }^{\circledR}$ - 3 minutos; (2) perborato de sódio Efferdent $\circledast$ - 15 minutos e (3) hipoclorito de sódio a $0,5 \%$ - 10 minutos. Os espécimes controle foram imersos em água destilada por 15 minutos. O número de células remanescentes após o tratamento foi observado com o auxílio de microscopia óptica (magnificação: 400x). Os produtos Polident $\circledast$ e Efferdent $\circledast$ não foram eficazes na prevenção da aderência inicial de Candida em condicionadores de tecido; já o hipoclorito de sódio apresentou significativa efetividade quando comparado aos outros higienizadores.

Paranhos et al. (2009) avaliaram três métodos de higienização de próteses totais: químico, mecânico e associação entre eles e seus efeitos sobre os diferentes tipos de microrganismos presentes no biofilme formado na superfície de resina acrílica termicamente ativada. Foram preparadas 220 amostras circulares, a partir de padrões de cera de $15 \mathrm{~mm}$ de diâmetro e $4 \mathrm{~mm}$ de altura. As amostras foram esterilizadas com gás de óxido de etileno para posterior contaminação por inóculo microbiano com $10^{6}$ unidades de colônias. A contaminação foi realizada a $37^{\circ} \mathrm{C}$ durante 48h, para as espécies: em cepas padrão (Staphylococcus aureus, Streptococcus mutans, Escherichia coli, Candida albicans, Pseudomonas aeruginosa, Enterococcus faecalis) e em cepas de campo (S. mutans, C. albicans, Candida glabrata e Candida tropicalis). Após a incubação e contaminação das cepas com determinado microrganismo, as amostras foram aleatoriamente higienizadas com os diferentes métodos. No método químico, as amostras foram imersas em um container com água destilada a $37^{\circ} \mathrm{C}$ e um tablete efervescente de peróxido alcalino (Bonyplus Tablets) por 5 minutos. No método mecânico, as amostras foram escovadas com escovas dentais de cerdas macias e dentifrício (Dentu Creme) por 20 segundos, com posterior imersão em água destilada por 5 minutos. $\mathrm{Na}$ associação dos métodos, as amostras passaram pelos dois procedimentos, iniciando pelo método mecânico seguido pelo químico. Além disso, foi realizado controle positivo e negativo do experimento: $O$ controle negativo foi realizado igual aos outros grupos, exceto pela não inoculação dos agentes. Este grupo foi obtido para avaliar a esterilização do material. No controle positivo, 5 amostras de cada 
microrganismo foram transferidas e avaliadas quanto a sua contaminação. Os resultados mostraram que não houve crescimento no controle negativo, assegurando a efetividade do procedimento de esterilização. No controle positivo houve crescimento de todas as amostras transferidas, o que confirma a eficiênciado procedimento de contaminação. Nas amostras que continham o inóculo microbiano, os resultaram mostraram que para $S$. mutans (padrão e experimental), S. aureus $e$ $P$. aeruginosa não houve diferença significante em seus crescimentos entre os métodos testados. Já para E. faecalis, $C$. albicans (padrão e experimental) e $C$. glabrata não houve diferença na efetividade dos métodos mecânico e a combinação entre o químico e mecânico, mas esses foram mais eficazes que o método químico. Para E. coli e $C$. tropicalis a combinação dos métodos foi mais eficaz do que o método mecânico. O método químico mostrou, em geral, resultados intermediários. Com isso, concluiu-se que os três métodos de higienização testados apresentam diferentes efeitos, sendo mais efetivos ou não, de acordo com o tipo de microrganismo presente no biofilme formado.

Rodrigues et al., 2009, avaliaram in vitro a retenção de o'ring (Neodent) em diferentes angulações de eixos de inserção/remoção $\left(0^{\circ}, 7^{\circ}\right.$ e $\left.14^{\circ}\right)$. Foi utilizado um dispositivo com posicionadores para compensar estas angulações, baseado na condição clínica do posicionamento dos implantes fora do eixo axial. Foram simulados 2900 ciclos de inserção/remoção (2 anos de uso), com 36 espécimes. Os conjuntos foram seccionados longitudinalmente para avaliar a relação entre eles. Para o grupo de $0^{\circ}$, a força de retenção diminuiu no primeiro ano de uso simulado. $\mathrm{Na}$ leitura inicial foi de $8,4 \mathrm{~N}$, após 6 meses foi de $7,07 \mathrm{~N}$, após 12 meses foi de 5,35 $\mathrm{N}$, após 18 meses foi de 4,39 $\mathrm{N}$ terminado a leitura de 24 meses em 3,69 N. Para o grupo de $7^{\circ}$, a força foi estatisticamente diferente nos tempos inicial e após 24 meses. Na leitura inicial foi de 6,28 N, após 6 meses foi de 5,82 N, após 12 meses foi de 6,03 N, após 18 meses foi de 5,52 $\mathrm{N}$ terminado a leitura de 24 meses em 5,37 $\mathrm{N}$. Já o grupo de $14^{\circ}$ apresentou perda de retenção significativa após 6, 12 e 24 meses. Na leitura inicial foi de 4,46 N, após 6 meses foi de $4,8 \mathrm{~N}$, após 12 meses foi de $5 \mathrm{~N}$, após 18 meses foi de $4,5 \mathrm{~N}$ terminado a leitura de 24 meses em 3,91 N.Os autores concluíram que os órings posicionados perpendicularmente ao plano oclusal ou até 7 graus apresentam retenção adequada ao longo do primeiro ano de uso e que a capacidade retentiva inicial é afetada pelo aumento da angulação do 
eixo de inserção/remoção da prótese. A angulação de 14 graus demosntrou retenção aquém da necessária para manutenção do conjunto em função.

Ferreira et al. (2009) realizaram um estudo in vitro para avaliar a eficácia de higienizadores de prótese na aderência da Candida albicans e Candida glabrata em reembasadores. O estudo objetivou também, apresentar correlação entre a rugosidade superficial e os níveis de aderência da Candida spp. Amostras de três reembasadores foram preparadas (seguindo orientações dos fabricantes) e tiveram suas rugosidades superficiais medidas. As amostras foram distribuídas, de forma randomizada, em 24 grupos $(n=8)$ para a realização dos ensaios de aderência dos microrganismos. Para simular condições in vivo, cada amostra recebeu, anteriormente ao processo de aderência, uma película de revestimento salivar obtida de um único voluntário, com quadro de saúde saudável. Após a contaminação do fungo, cada amostra recebeuum tratamento de imersão: água destilada por 15 minutos (T1- controle negativo), solução higienizadora enzimática (Polident) por 3 minutos (T2), solução higienizadora (Efferdent) por 15 minutos (T3) ou solução de hipoclorito de sódio a $0,5 \%$ por 10 minutos (T4). Após tratamento, as células fúngicas aderentes remanescentes foram contadas por meio de um microscópio de luz (x400). Os resultados mostraram que a C. glabrata apresentou elevado número de células aderentes remanescentes para todos os tratamentos quando comparada à C. albicans, exceto para o tratamento com hipoclorito de sódio a $0,5 \%$ que foi o único capaz de reduzir a aderência das duas espéciesde Candida, tendo apresentado a mesma efetividade em relação aos dois grupos. Os higienizadores de prótese e o grupo controle não apresentaram diferenças significativas. Não houve correlação entre a rugosidade superficial e a aderência de $C$. albicans e $C$. glabrata em todos os materiais testados.

Montagner et al. (2009) avaliaram a ação antifúngica de diferentes agentes de limpeza sobre espécimes de resina acrílica polimerizados em micro-ondas, sem polimento e previamente contaminados com Candida albicans. Sessenta espécimes foram imersos em caldo $\mathrm{BHI}$ inoculado com fungo e incubados por $3 \mathrm{hs}$ a $37^{\circ} \mathrm{C}$ e distribuídos em 5 grupos experimentais e dois grupos controles: G1- clorexidina a 2,0\% (10 minutos); G2- hipoclorito de sódio a 0,5\% (10 minutos); G3- hipoclorito de sódio modificado (10 minutos); G4- peróxido alcalino Corega Tabs® (5 minutos); G5peróxido de hidrogênio a 10v (30 minutos); C1- espécimes controle contaminados, 
imersos em solução salina (10 minutos) e C2- espécimes controle sem contaminação, imersos em solução salina (10 minutos). Após imersão nos agentes de desinfecção os espécimes foram imersos em caldo $\mathrm{BHI}$ por $24 \mathrm{hs}$. A turvação do meio de cultura foi avaliada de acordo com o coeficiente de transmitância (transmissão de luz), com o auxílio de um espectrofotômetro. Assim, quanto mais elevado fosse o coeficiente de transmitância, maior seria considerada a ação antimicrobiana do higienizador. Os resultados mostraram que o hipoclorito de sódio e o peróxido de hidrogênio foram mais eficazes para redução de Candida albicans que a clorexidina e o peróxido alcalino.

de Souza et al. (2009) realizaram uma revisão sistemática a respeito da eficácia e segurança de diferentes métodos de limpeza de próteses removíveis. Os bancos de dados pesquisados foram: Cochrane Oral Health Group Trials Register (até maio de 2009), CENTRAL (The Cochrane Library 2009, Edição 2), MEDLINE (1965 a maio de 2009), EMBASE (1980 a maio de 2009), LILACS (1980 a Maio de 2009) e CINAHL (1997 a maio de 2009).Não houve restrição de idioma. Os critérios de seleção dos estudos foram: ensaios clínicos randomizados (ECR) comparando qualquer método mecânico (escovação ou ultrassom, por exemplo) ou químico (enzimas, hipoclorito de sódio, enxaguatórios bucais ou soluções de peróxido, por exemplo) em adultos com mais de 18 anos usuários de prótese parcial removível ou prótese total. Com relação aos resultados, embora seis ensaios clínicos tenham sido incluídos nesta revisão, a ampla gama de intervenções e desfechos não permitiu a partilha de dados em meta análise. Relatos isolados indicaram que a associação de produtos químicos com a escovação parece mais eficaz que o placebo na redução do biofilme e na contagem de microrganismos aeróbios e anaeróbios na superfície das próteses totais. De acordo com os autores, há falta de evidências sobre a eficácia comparativa de diferentes métodos de limpeza de dentaduras considerados na revisão. Poucos estudos clínicos randomizado sbem estruturados foram encontrados. Sugeriram que pesquisas futuras fossem realizadas de modo a focalizar a comparação entre os métodos mecânicos e químicos, a associação de métodos, variáveis primárias e custos.

Barão et al., em 2009, avaliaram por meio da análise de elementos finitos o comportamento de overdentures retidas por implantes. Quatro grupos foram analisados: A - prótese total (controle), B - overdenture retida por barra/clipe sobre 
dois implantes, C - overdenture retida por o'ring sobre dois implantes e D overdenture retida por barra/clipe sobre dois implantes, com o'rings distais. Foi aplicada uma carga vertical de $100 \mathrm{~N}$ sobre o incisivo central. $\mathrm{O}$ menor estresse foi observado no grupo A, seguido pelos grupos C, D e B. O uso de o'rings apresentouse mais favorável quando foi observada a distribuição de cargas nos tecidos de suporte periimplantares.

Em 2010, o governo federal emitiu a Portaria 718/SAS que estabelece 0 fornecimento de implantes osseointegrados e próteses sobre implantes para a população, incluindo overdentures retidas por barra/clipe ou o'ring, com atuação nas esferas estaduais e municipais, por meio dos Centros de Especialidades Odontológicas (CEOs).

Nguyen et al., em 2010, avaliaram o efeito de agentes higienizadores (água, Polident Regular, Efferdent, hipoclorito de sódio 6,15\% diluído na proporção 1:10, Polident Overnight, Listerine) na retenção do encaixe Locator cor-de-rosa, durante período equivalente a 6 meses de uso. A força de tração foi medida após as imersões, por meio de máquina de ensaios mecânicos, com velocidade de 2 $\mathrm{mm} / \mathrm{min}^{-1}$. Os resultados demonstraram que o Listerine propiciou aumentou da retenção do Locator quando comparado com o grupo controle. Não houve diferenças entre os tipos de Polident e o grupo o controle. A pastilha Efferdent causou leve redução na retentividade do sistema e o hipoclorito, acentuada perda de retenção. Os autores relataram que o Listerine causou manchamento e o hipoclorito, amolecimento e branqueamento do encaixe. Desta forma, concluíram que o Listerine e o hipoclorito não são indicados para a higienização de overdentures com encaixes do tipo Locator, entretanto, sugeriram avaliação clinica e associação com ensaios de fadiga para melhor entendimento da ação de soluções durante determinados períodos.

Vieira et al. (2010) estudaram a eficácia de higienizadores de próteses em relação à recolonização do biofilme por Candida spp. formado na superfície de reembasadores. Biofilmes de C. albicans ou C. glabrata foram formados sobre a superfície de espécimes de reembasadores após $48 \mathrm{~h}$, e então os espécimes foram submetidos aleatoriamente a um dos seguintes tratamentos: peróxido alcalino, hipoclorito de sódio a $0,5 \%$ ou água destilada. Após os tratamentos, o biofilme dos 
espécimes foi desprendido por sonificação e as células residuais foram contadas. Os resultados mostraram que o tratamento com peróxido alcalino foi melhor que o controle, entretanto; não foi efetivo na remoção de Candida do biofilme de condicionadores de tecido e na prevenção da recolonização de biofilme. O hipoclorito de sódio foi o único tratamento que removeu efetivamente o biofilme, uma vez que nenhuma célula viável foi encontrada após seu uso.

Uludamar et al. (2010) avaliaram, in vivo, a eficácia de pastilhas efervescentes à base de peróxido alcalino (Polident ${ }^{\circledR}$, Efferdent ${ }^{\circledR}$ e Fittydent ${ }^{\circledR}$ ) e de enxaguatórios bucais (CloSYS II $\circledast$ - clorexidina a $2 \%$ e Corsodyl $\circledast$ - dióxido de cloro), na eliminação de Candida albicans do biofilme de próteses totais. Noventa usuários de próteses totais com evidências clínicas de Estomatite Protética, foram distribuídos aleatoriamente em 6 grupos (5 testes e 1 controle). Cada grupo foi dividido em 3 subgrupos em que as próteses eram submetidas a 15, 30 e 60 minutos de desinfecção. As próteses de cada grupo teste foram tratadas com um dos higienizadores, enquanto que as do grupo controle foram tratadas com água destilada. Amostras de biofilme foram colhidas da superfície palatina das próteses antes e após 15, 30 e 60 minutos do uso dos higienizadores. Após o exame micológico, os resultados mostraram que, em todos os períodos de tempo testados, os enxaguatórios promoveram redução significativamente maior de Candida albicans que o grupo controle. Além disso, em todos os períodos testados, não houve diferença estatisticamente significante entre Polident ${ }^{\circledR}$, Efferdent ${ }^{\circledR}$ e controle. As próteses tratadas com Fittydent ${ }^{\circledR}$ somente apresentaram redução significativa do número de Candida spp após 60 minutos de tratamento. Os autores concluíram que o uso de enxaguatórios reduz significativamente o número de microrganismos do biofilme de próteses totais.

Van der Bilt et al., 2010, correlacionaram o uso de próteses totais mandibulares retidas por implantes e a função mastigatória. Foram quantificadas a força de mordida e o desempenho mastigatório dez anos após instalação. Foram selecionados e reabilitados 18 pacientes, entretanto somente 14 retornaram após os dez anos. Os resultados demonstraram que a força de mordida foi maior, mais que 0 dobro da inicial (de 162 para $341 \mathrm{~N}$ ) e o número de ciclos para triturar o mesmo cubo de material de moldagem caíram de 55 para 27 ciclos. Apesar de ter havido aumento dos parâmetros avaliados, os autores ressaltaram que a força de mordida 
ainda é consideravelmente menor que a força encontrada em pacientes dentados (569 N).

Tabatabaian, Alaie e Seyedan, em 2010, compararam a retenção e resistência de três tipos de encaixes para overdentures (o'ring e barra/clipe da Nobel e ERA vermelho). Os pesquisadores utilizaram cinco amostras para cada grupo. A força de deslocamento foi aplicada nos sentidos vertical, oblíquo e ântero-posterior, em dois tempos: antes da realização dos ciclos e após cem ciclos de inserção e remoção. Todos os sistemas apresentaram perda da retenção após os ciclos de inserção. O sistema ERA, apresentou-se resistente nas duas situações, entretanto sem desqualificar os demais grupos, que também apresentaram altos níveis de retenção.

Ramage et al., 2011, estudaram a prevalência de Candida albicans em próteses totais de pacientes com estomatite protética. Uma área de $1 \mathrm{~cm}^{2}$ e $1 \mathrm{~mm}$ de espessura foi avaliada após higienização por pastilha efervescente à base de perborato de sódio por 4 dias seguidos ou após o intervalo de uso, sendo um dia utilizada pastilha, dois dias escovação e o quarto dia com pastilha. As unidades formadoras de colônia foram avaliadas, assim como o nível de recolonização. Os autores utilizaram microscopia eletrônica de varredura para análise qualitativa da superfície. Os resultados demonstraram que o tratamento sequencial com a pastilha foi mais eficiente que o segundo tratamento. Desta forma, os autores sugeriram que o uso de higienizador químico deve ser empregado como rotina pelos pacientes, devido à dificuldade de eliminação da contaminação pelo método mecânico.

Felipucci et al.(2011a) avaliaram o efeito de diferentes higienizadores diários (Periogard, Cepacol, Corega Tabs, Medical Interporous, Polident, hipoclorito de sódio 0,05\% e água destilada) na superfície das próteses parciais removíveis. Cinco discos de cobalto-cromo (DeguDent e VeraPDI) foram inseridos em retângulos de resina acrílica termopolimerizável. Foram simulados 180 dias de imersão e a rugosidade superficial $(\mathrm{Ra}, \mu \mathrm{m})$ foi aferida no metal e na resina, e não houve influência nesta propriedade. Visualmente, pôde-se observar manchas nas ligas quando imersas em Medical Interpourous e hipoclorito de sódio. Além disso, foram realizadas micrografias para avaliar os manchamentos superficiais e por meio da espectrometria de energia dispersiva (EDS) foi constatada a presença de oxigênio 
nas duas ligas quando imersas na Medical Interpourous e no hipoclorito de sódio 0,05\%, sugerindo corrosão. Esses achados comprovaram o que foi verificado na análise visual dos espécimes. Desta forma, os autores contra-idicaram o uso dessas soluções em próteses removíveis com componentes metálicos de cobalto-cromo.

Felipucci et al., (2011b) avaliaram in vitro o efeito de diferentes soluções higienizadoras (Periogard, Cepacol, Corega Tabs, Medical Interporous, Polident, hipoclorito de sódio $0,05 \%$ e água destilada) na alteração de massa e liberação de íons em próteses parciais removíveis. Cinco discos de cobalto-cromo (DeguDent e VeraPDI) foram inseridos em retângulos de resina acrílica termopolimerizável. Foram simulados 180 dias de imersão nestas soluções e uma balança analítica de alta precisão foi utilizada para aferir a massa antes e após as imersões. Os grupos de Corega Tabs e Medical Interporous apresentaram maior perda de massa, sendo maior a perda na liga VeraPDI. As soluções de Medical Interpourous e hipoclorito de sódio apresentaram maior liberação de íons, quando analisadas em espectrometria de massas por plasma induzido. Os autores concluíram que essass soluções não são adequadas para o uso diário na higienização de próteses parciais removíveis.

Felton et. al., em 2011, apresentaram para a comunidade científica um guia de cuidados na manutenção das próteses totais acrílicas. Entre os ítens colocados, além dos aspectos mecânicos, de preservação e periodicidade de retorno ao profissional, os autores sugeriram alguns cuidados visando melhor higienização: remoção diária do biofilme da prótese e da cavidade oral, fundamental para minimização da estomatite; limpeza da prótese realizada diariamente por meio de escovação com pastas não-abrasivas e uso de soluções de imersão somente fora da cavidade oral; as próteses devem ser bem enxaguadas após escovação e imersão em soluções higienizadoras diárias, devendo seguir as instruções dos fabricantes; as próteses devem ser higienizadas pelo menos anualmente por um profissional; as próteses não devem ser imersas em água fervente, hipoclorito de sódio, ou produtos que contenham hipoclorito de sódio, por períodos superiores a 10 minutos.

Burns et al., em 2011, avaliaram três tipos de tratamento com overdentures (barra com 2 implantes, barra com 4 implantes e o'ring em 2 implantes). A avaliação dos métodos foi realizada usando questionários de satisfação sobre a percepção de 
qualidade da prótese e outro da habilidade mastigatória. Os autores concluíram, baseados nos resultados, que a qualidade de retenção é menos importante que os parâmetros clínicos de satisfação, como espaço na base da prótese que facilita a higienização. Os pacientes mostraram preferência ao uso de dois implantes com o'ring, mesmo que a retenção deste tipo de encaixe tenha sido inferior às barras.

You et al., em 2011, avaliaram o efeito de soluções higienizadoras (Efferdent, Polident Overnight, hipoclorito de sódio 6,15\% diluídos na proporção 1:10, Listerine e água, como controle) na retenção de Locators cor-de-rosa $(n=5)$. Foram simulados 6 meses de uso clínico. O valor final de resistência à tração após 548 ciclos de inserção/remoção foi comparado com o valor inicial. Os resultados demonstraram que as soluções influenciaram a retenção do encaixe ao final dos ciclos de inserção e remoção A retenção inicial foi diminuída em 29\% para o Listerine, 49\% para Efferdent, 34\% com uso da Polident e $42 \%$ quando o hipoclorito foi utilizado.. Os valores absolutos propiciados pela Efferdent, Listerine, Polident Overnight e água foram superiores quando comparados com o hipoclorito. s autores concluíram que o hipoclorito não deve ser indicado como auxiliar na higienização. Já o Listerine aumentou a retenção do Locator, entretanto, os autores consideraram prematuro indicá-lo como o higienizador de escolha.

Petropoulos e Mante (2011) avaliaram a retenção e sobrecarga de encaixes para overdentures (o'ring padrão e mini, um do sistema Zest convencional e o novo desenho - macho metálico e dois do sistema ERA - branco e laranja). Quando avaliada a força retentiva vertical e deslocamento oblíquo, o novo desenho da Zest foi superior aos demais grupos, entretanto o o'ring padrão também apresentou índices elevados de resistência.

Rutkunas et al., em 2011 avaliaram o desgaste de alguns encaixes para overdentures (Locator rosa, branco e preto, ERA branco e laranja, e um encaixe japonês conhecido como OP, que é de ouro e borracha). Os autores simularam o uso contínuo dos conjuntos, fazendo 15000 ciclos de inserção e remoção e avaliando posteriormente em microscópio eletrônico de varredura. Após a ciclagem, os encaixes perderam de 21 a $80 \%$ da retenção inicial.

Bilhan et al., em 2011, relataram os resultados clínicos após um ano de instalação de 59 overdentures mandibulares, retidas por dois ou três implantes 
associados com Locator e o'ring, ou com três ou quatro implantes associados com umabarra. No exame clínico foram avaliadas oclusão, adaptação tecidual e capacidade retentiva. Não houve correlação significativa entre o tipo de encaixe, força de mordida, número de implantes e complicações, exceto pela predominância da necessidade de reembasamento nas próteses com o'rings.

Yang et al., 2011 avaliaram a influência da inclinação dos implantes nas forças laterais e de retenção. Foram utilizados os sistemas Locator preto e azul, encaixe do tipo o'ring, um magnético convencional e outro magnético com liberdade rotacional. Os implantes foram posicionados em zero, 15, 30 e 45 graus e a inserção e remoção foram simuladas por dez vezes. Os resultados demonstraram que, com o aumento da angulação, a força de retenção diminui. A retenção maior foi alcançada pelos Locators seguidos pelos encaixes o'ring e depois os magnéticos.

Machado et al., 2011, avaliaram a distribuição de cargas axiais nos diferentes métodos de fixação de próteses totais sobre implantes osseointegráveis (o'ring, barra clip e associação dos dois métodos) por meio de análise fotoelástica. $O$ sistema o'ring apresentou os melhores resultados de distribuição, demonstrando menor nível de sobrecarga nos implantes e na porção distal. Já o método associado apresentou o pior resultado devido aos altos níveis de tensão concentrada principalmente nos implantes distais e à falta de distribuição de cargas entre os demais implantes e barra, tendo causado sobrecarga nesses elementos.

André et al., em 2011, avaliaram a efetividade de enxaguatórios bucais (Cepacol, Plax e Periogard) em formas sésseis de $S$. mutans presentes em próteses totais acrílicas após utilização de dentifrício comercial (Kolynos Super White) e um dentifrício experimental. Setenta e duas próteses foram utilizadas, e divididas em dois grupos baseados nos dentifrícios utilizados. O biofilme foi coletado no tempo zero, após 90 e 180 dias depois da escovação com solução salina. Após as diluições o biofilme foi aplicado com as diferentes soluções em placas de Petri e a mínima concetração inibitória e máxima diluição inibitória foram avaliadas. Houve incidência de S. mutans em $74 \%$ das próteses, e o número foi descrescente nas 3 leituras, independente do grupo. Para os dois grupos, os enxaguatórios mostraram efetividade antimicrobiana, sendo o Periogard o que mais permitiu diluição sem perder ação, seguido pelo Cepacol e Plax. 
Fais et al., em 2012, avaliaram a influência do fluoreto na topografia do titânio cp e Ti-6Al-4V, simulando 10 anos de escovação. Foram agrupados da seguinte forma $(n=6)$ : I: imersão, II: escovação usando as soluções de água deionizada (W), dentifrício sem flúor (T) e com flúor (FT). A topografia foi avaliada por meio de microscopia de força atômica. A imersão foi realizada sem escovação e a escovação foi realizada utilizando uma máquina de escovação por 244 h. Além disso, os corpos-de-prova IFT e BFT foram analisados utilizando o EDS. Não foram encontradas diferenças significativas após as imersões. Quando foram escovados, a rugosidade aumentou: no Ti cp, após uso das combinações BW, BT e BFT e para o Ti-6Al-4V, nos grupos BT e BTF. O EDS não detectou presença de flúor nas superfícies. Os autores discutiram que a presença de flúor nos dentifrícios e enxaguatórios bucais podem causar efeitos deletérios nas ligas à base de titânio e no próprio Ti cp. Este íon pode diminuir a resistência das ligas metálicas, deixandoos propensos à corrosão. Os autores concluíram que a escovação associada com o fluoreto pode aumentar a rugosidade do Ti e liga avaliados.

Emami et al., em 2012, realizaram uma revisão sistemática para avaliar se havia evidências sobre a associação de estomatite protética em pacientes usuários de próteses parciais removíveis. Foram utilizadas as plataformas MEDLINE, EMBASE e bases Cochrane. Todos os estudos que envolviam estomatite protética e próteses parciais removíveis foram incluídos. Escalas avaliavam a qualidade metodológica e o nível de evidência, e foram utilzadas por dois autores separadamente. Apenas oito estudos atenderam aos critérios. A prevalência da patologia nos usuários variou de $1,1 \%$ a $36,7 \%$, o que levou à conclusão, apesar de algumas limitações, que há evidência científica da hipótese.

Fatalla et al., em 2012, avaliaram a força de retenção e resistência à fadiga de vários desenhos de overdentures suportadas por implante. Os autores discutiram a variedade de resultados encontrados na literatura, que, muitas vezes são discordantes da média, uma vez que há relatos na literatura de forças de retenção variando de 1 a $85 \mathrm{~N}$. Os autores criaram modelos de suporte triangular e quadrangular, variando os encaixes - o'ring e acrílicos flexíveis. Os conjuntos foram submetidos à ciclagem (simulando 3 e 6 meses, 1 e 2 anos) e o melhor resultado de retenção foi obtido quando o encaixe acrílico flexível foi associado à distribuição quadrangular. 
Davi et al., em 2012, avaliaram o efeito de higienizadores diários (hipoclorito de sódio 0,05\%, Periogard, Cepacol, Corega Tabs, Medical Interporous, Polident e água deionizada) na liberação de íons e na rugosidade do titânio cp (Tritan), de ligas metálicas (níquel-cromo - Vi-Star e FitCast-SB Plus, e níquel-cromo-berílio (Fit Cast V) e da resina acrílica termopolimerizável, simulando 180 imersões. Os discos metálicos foram confeccionados e incluídos em resina. Os espécimes $(n=5)$ foram imersos seguindo os tempos preconizados pelos fabricantes. A análise quantitativa de liberação de íons foi realizada por meio do método de espectrometria de massa por plasma induzido.. A rugosidade superficial $(\mu \mathrm{m})$ foi mensurada por meio de um rugosímetro. As ligas Vi-Star e Fit Cast-V promoveram liberações significativas após imersão na solução Medical Interporous. Houve diferença significativa na rugosidade superficial da resina acrílica termopolimerizável após imersão no Cepacol. Entretanto, nenhum produto teve influência na rugosidade superficial de nenhuma liga metálica. Os autores concluíram que as soluções Cepacol e Medica Interporous devem ser usadas com cautela, devido aos efeitos causados.

Dhamande et al., 2012, avaliaram o efeito de três higienizadores de prótese (Viclean - hipoclorito de sódio, Clinsodent - lauril sulfato de sódio e Fittydent hipoclorito de sódio na remoção de Candida albicans). Foram utilizados quadrados de resina acrílica termopolimerizável para realizar a contaminação. Os resultados demonstraram que o Clinsodent apresentou melhor efeito removedor.

Toniollo et al., em 2012, avaliaram o efeito do fluoreto de sódio de enxaguatórios bucais ( $\mathrm{NaF} 0,05 \%$ e $\mathrm{NaF} 0,2 \%$ ) no $\mathrm{Ti} \mathrm{cp}$ modificando o tempo de exposição. Os grupos foram: GA - água destilada (controle); GB: NaF 0,05\% por 3 minutos diariamente; GC: $\mathrm{NaF} 0,2 \%$ por 3 minutos diariamente; GD: NaF $0,05 \%$ por 3 minutos a cada 2 semanas; GE: NaF $0,2 \%$ por 3 minutos a cada 2 semanas. $O$ tempo experimental foi de 60 dias e a rugosidade foi aferida antes de se iniciar os ensaios a cada 15 dias até completar o tempo proposto. Após 60 dias, a análise de corrosão e de polarização anódica foram realizadas. Os espécimes foram também avaliados por microscopia eletrônica de varredura. Não houve diferença ente os grupos quanto à rugosidade. Quanto a corrosão, houve diferenças entre os grupos GA e GC, GB e GC, GC e GD, GC e GE. As eletromicrografias corroboraram com estes achados. Os autors concluíram que na concentração de $0,05 \%$ o fluoreto pode 
ser empregado. Entretanto deve-se ter cautela ao indicar o fluoreto $0,2 \%$ diariamente.

Suzuki, Ohkubo e Kurtz (2013) apresentaram um caso clínico em que foram utilizados dois encaixes conhecido como SBB - stress breaking ball, associados com uma prótese parcial removível, classe I de Kennedy. Segundo os autores, esse encaixe permite a acomodação de três alturas de cápsulas $(0.3,0,5$ ou $0,7 \mathrm{~mm})$, tendo sua seleção baseada na espessura, na resiliência da mucosa e na força oclusal. $O$ anel o'ring acomodado na cápsula é feito de nitrilo-butadieno, um tipo de borracha. Os autores citaram como vantagens desse encaixe quando comparado com o o'ring convencional, a prevenção de sobrecarga no implante e a transmissão vertical da força recebida, tendo promovido grande êxito no tratamento reabilitador. 
3 Proposição 
O objetivo deste trabalho foi:

1) Avaliar a força de retenção do sistema de encaixe do tipo o'ring (Conexão Sistemas de Prótese) quando imerso em soluções auxiliares de higienização: Cepacol, Cepacol Flúor, Listerine, hipoclorito de sódio 0,05\%, água deionizada (controle).

2) Realizar a análise qualitativa da superfície dos anéis de borracha por meio de microscopia eletrônica de varredura como forma de esclarecer os valores de retenção obtidos. 
4 Material e Métodos 


\subsection{Delineamento Experimental}

O plano piloto foi elaborado com a finalidade de estabelecer as imersões a serem realizadas. Os fatores de variação foram: Imersão em soluções auxiliares de higienização (S) em 5 níveis: S1. Água deionizada, S2. Cepacol, S3. Cepacol Flúor, S4. Listerine e S5. hipoclorito de sódio 0,05\% e Tempos de leitura (T) em 4 níveis: T0. pré-imersão, T1. após 10 dias (30 imersões), T2. após 20 dias (60 imersões), T3. após 30 dias (90 imersões) A amostra do experimento foi composta por 30 espécimes que foram divididos em 5 grupos experimentais.

\subsection{Material}

Para avaliação da força de retenção do sistema de encaixe o'ring (Conexão Sistemas de Prótese) foi realizada a imersão dos espécimes em água deionizada (controle) e nas seguintes soluções auxiliares de higienização: Cepacol, Cepacol Flúor, Listerine e hipoclorito de sódio 0,05\%.

Os corpos-de-prova foram imersos em $50 \mathrm{~mL}$ das soluções higienizadoras propostas pelo período de 8 horas (overnight) com obtenção dos valores de resistência à tração ao final de cada 10 dias, o que equivale ao total de 30 imersões, uma vez que cada dia possui 24 horas e possibilita a simulação de 3 períodos de 8 horas (10 dias $\times 3$ imersões diárias $=30$ imersões neste período). Cada período de 30 simulações, desta forma, corresponde a um mês de uso pelo paciente. Foram realizadas desta forma, três leituras de tração, além da inicial, perfazendo um total de 3 meses de uso das soluções.

Para a obtenção dos corpos-de-prova foi utilizada uma modificação da metodologia descrita por Botega et al., 2004. Foram utilizadas cápsulas com anéis de borracha dos sistemas de encaixe o'ring da marca comercial Conexão Sistemas de Prótese Ltda.

Os materiais utilizados estão descritos na Tabela 1. 
Tabela 1: Material

\begin{tabular}{|c|c|c|}
\hline Produto & Fabricante & Lote \\
\hline $\begin{array}{l}\text { Resina Acrílica } \\
\text { Autopolimerizável (pó- } \\
\text { (polimetilmetracrilato) }\end{array}$ & $\begin{array}{l}\text { VIPI Indústria, Comércio, Exportação e } \\
\text { Importação de Produtos Odontológicos } \\
\text { Ltda, Pirassununga, SP, Brasil. }\end{array}$ & 00979 \\
\hline $\begin{array}{l}\text { Líquido (monômero de } \\
\text { metilmetacrilato) }\end{array}$ & $\begin{array}{l}\text { VIPI Indústria, Comércio, Exportação e } \\
\text { Importação de Produtos Odontológicos } \\
\text { Ltda, Pirassununga, SP, Brasil. }\end{array}$ & 12068 \\
\hline $\begin{array}{l}\text { Análogo Implante 3,75 x } \\
10 \mathrm{HI}\end{array}$ & $\begin{array}{l}\text { Conexão Sistemas de Prótese Ltda, } \\
\text { Arujá, SP, Brasil. }\end{array}$ & 115458 \\
\hline Cápsula O'Ring & $\begin{array}{l}\text { Conexão Sistemas de Prótese Ltda, } \\
\text { Arujá, SP, Brasil. }\end{array}$ & 118745 \\
\hline Pilar O'Ring & $\begin{array}{l}\text { Conexão Sistemas de Prótese Ltda, } \\
\text { Arujá, SP, Brasil. }\end{array}$ & 118745 \\
\hline Cepacol Tradicional & $\begin{array}{l}\text { Sanofi-Aventis Farmacêutica Ltda., } \\
\text { Suzano, SP, Brasil. }\end{array}$ & L215304 \\
\hline Cepacol Flúor & $\begin{array}{l}\text { Sanofi-Aventis Farmacêutica Ltda, } \\
\text { Suzano, SP, Brasil. }\end{array}$ & L243501 \\
\hline Listerine & McNeil LA LLC, Cali, Colômbia & 2801WL20 \\
\hline $\begin{array}{l}\text { Hipoclorito de sódio de } \\
2,5 \%\end{array}$ & Total Química Ltda, Embu, SP, Brasil & L12/318E11 \\
\hline
\end{tabular}

\subsection{Confecção das amostras}

Para a obtenção de um suporte para fixar os análogos e um contra-suporte para alojar as cápsulas, foram utilizadas bases de teflon com 2,0 cm de altura x 3,5 cm de diâmetro, confeccionadas na Oficina do Departamento de Materiais Dentários e Prótese da FORP-USP. Os dois análogos de implantes de encaixe interno com diâmetro de $3,75 \mathrm{~mm}$ por $10 \mathrm{~mm}$ de comprimento foram posicionados com a distância de $22 \mathrm{~mm}$ entre si, do centro do análogo ao outro (esta distância corresponde, aproximadamente, à distância entre dois caninos). Os pilares óring, conhecidos como machos, foram instalados sobre os análogos por rosqueamento utilizando um torquímetro protético (Conexão Sistemas de Prótese Ltda) com torque de 20 N.cm, conforme instruções do fabricante do implante Uma única base foi 
utilizada para obtenção de todos os grupos experimentais (Figura 1), visando a captura das cápsulas metálicas (Figura 2).
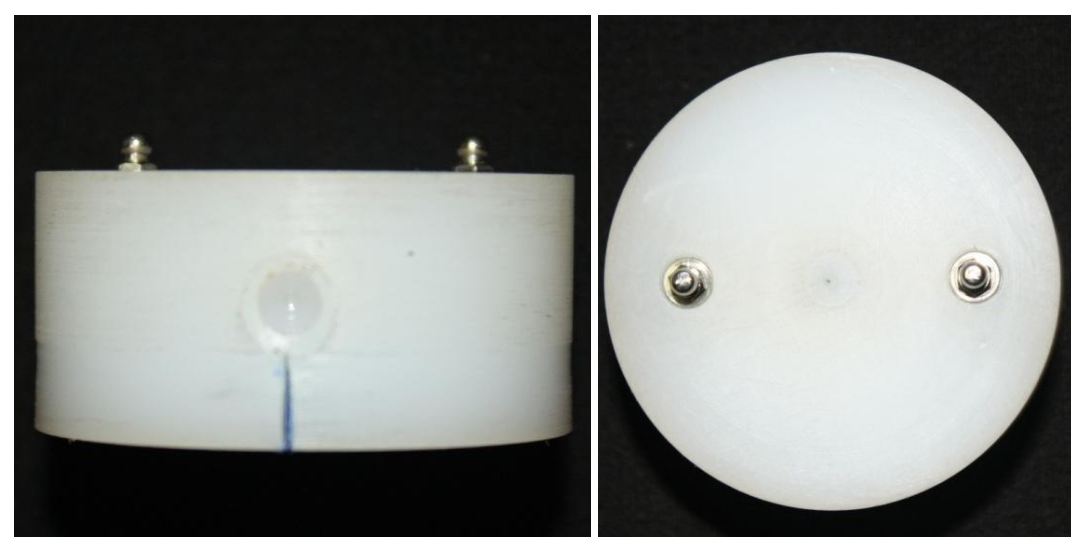

Figura 1: Base com análogo e pilares o’ring posicionados.

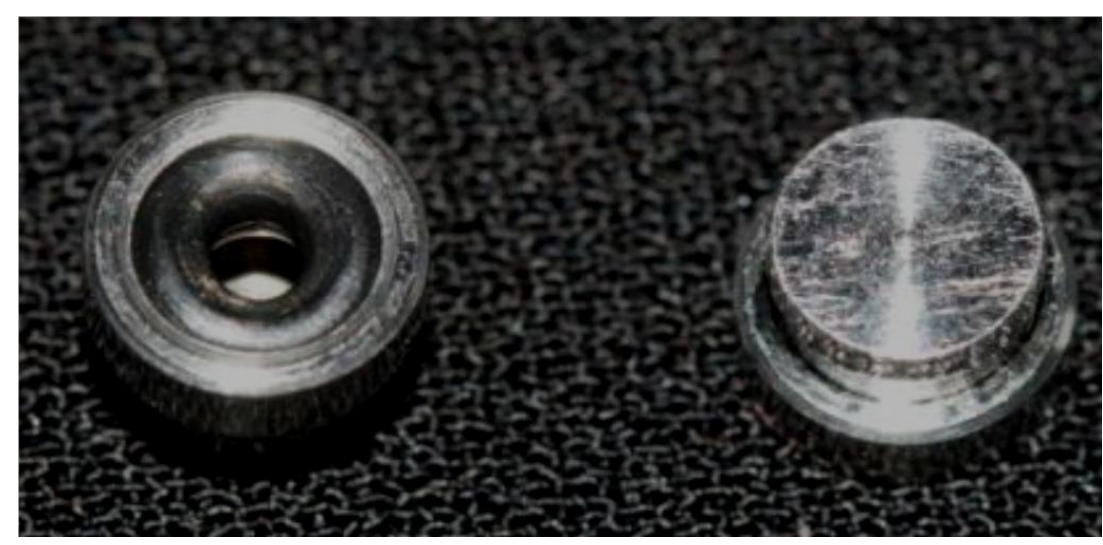

Figura 2: Cápsulas com anel de borracha.

Os corpos-de-prova foram confeccionados com a utilização de uma matriz em PVC confeccionada na Oficina do Departamento de Materiais Dentários e Prótese da FORP-USP (Figura 3). Este dispositivo em teflon foi desenvolvido para criar um alívio nas regiões correspondentes aos nichos que acomodariam as cápsulas definitivas. A resina acrílica foi manipulada com a proporção de $10 \mathrm{ml}$ de líquido para $30 \mathrm{~g}$ de pó em pote tipo paladon. Em seguida, o material foi vertido na matriz. Após a polimerização da resina acrílica, os corpos-de-provas foram removidos (Figura 4). 

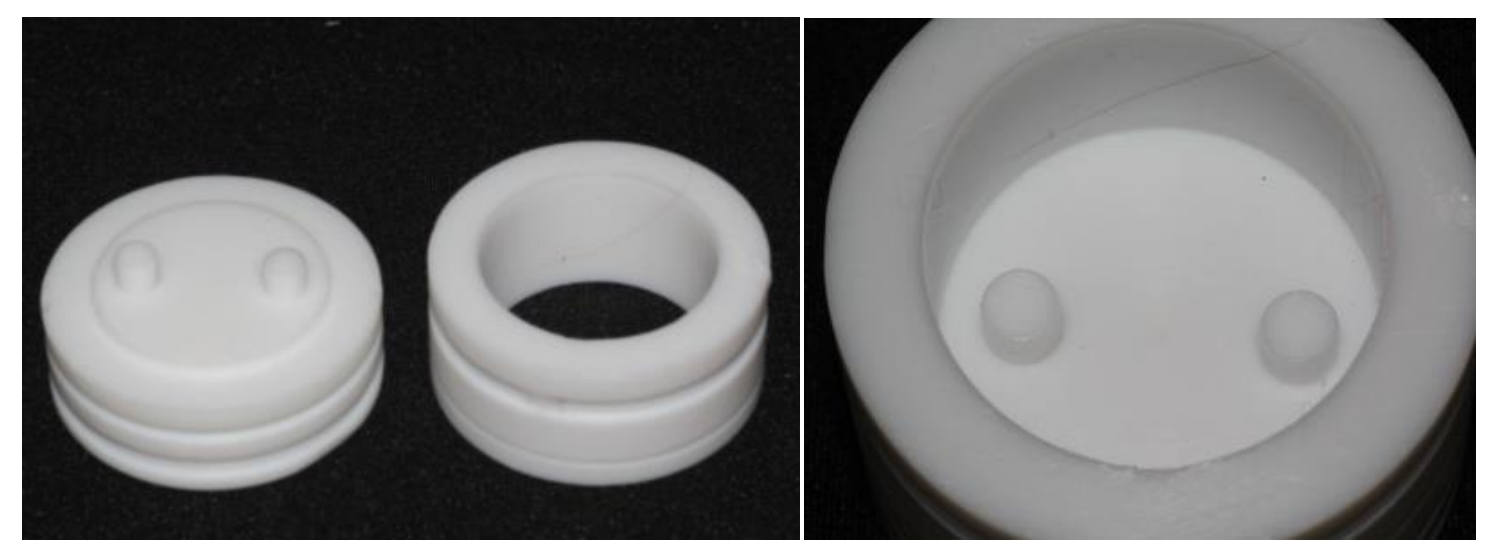

Figura 3: Matriz utilizada para obtenção dos corpos-de-prova.

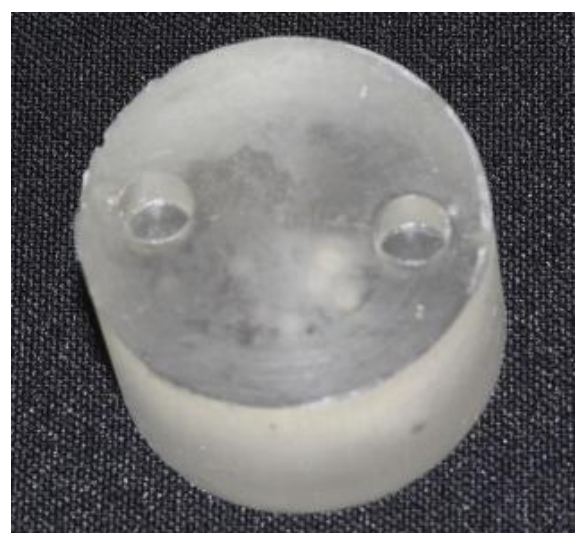

Figura 4: Corpo-de-prova aliviado para receber as cápsulas metálicas.

Para obtenção da contra-base em resina acrílica quimicamente ativada para acomodar as cápsulas, uma matriz confeccionada também em teflon associada com PVC foi desenvolvida para ser adaptada sobre a base com os análogos, servindo de molde para a confecção dessas amostras com as mesmas dimensões do anel da base (Figura 5).
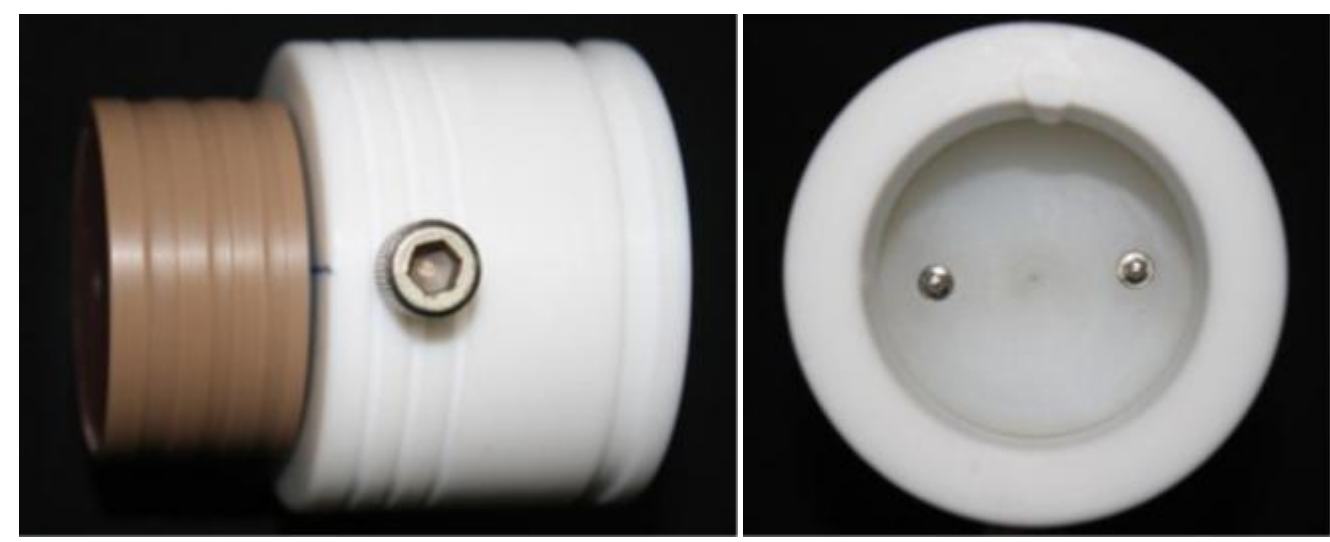

Figura 5: Contra base em resina acrílica utilizada para captura das cápsulas. 
Após o encaixe das cápsulas sobre os o'rings, uma pequena porção de resina acrílica quimicamente ativada foi inserida na fase fluida no topo da cápsula por meio de um pincel e a contra-base aliviada foi encaixada sobre o conjunto com o auxilio de um índice de posicionamento confeccionado na matriz de teflon (Figura 6) que foi novamente encaixada sobre a base com os análogos.

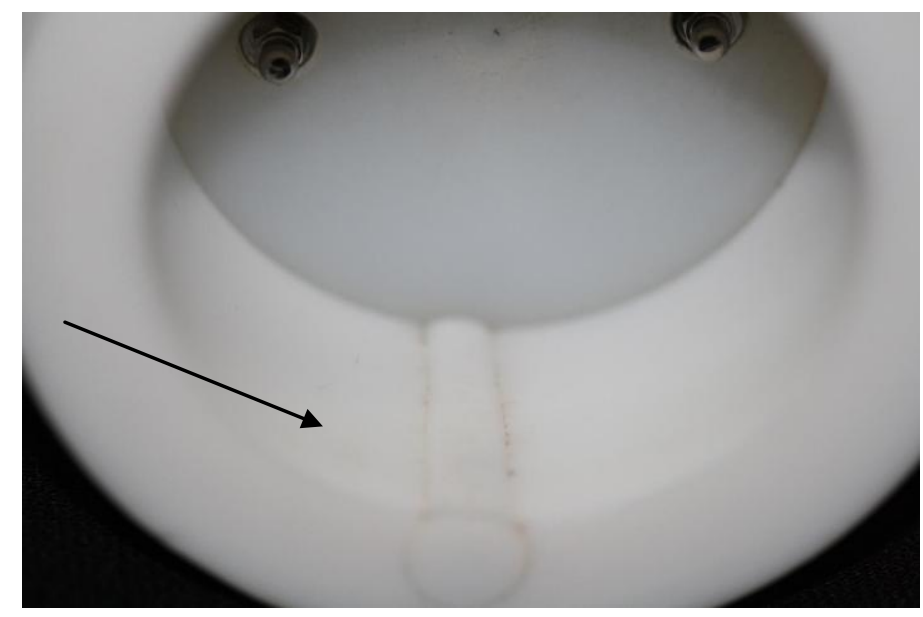

Figura 6: Decalque em positivo para padronizar o reposicionamento da contra-base para captura das cápsulas definitivas (flecha).

Após polimerização, as partes da base foram separadas, obtendo-se, assim, a contra-base com as cápsulas capturadas (Figura 7). Em alguns casos, pequenos incrementos de resina foram alocados para total preenchimento ao redor da cápsula.
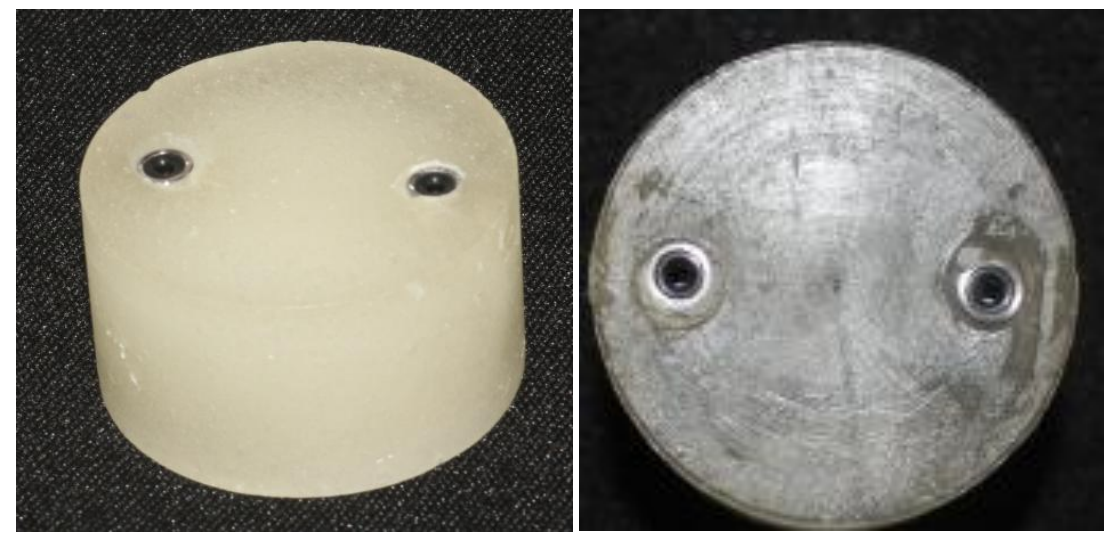

Figura 7: Corpos-de-prova com cápsulas capturadas na contra-base. 
Os corpos-de-prova foram submetidos ao acabamento realizado manualmente com lixas d'água de granulações 200, 400, 600 e 1200 com o objetivo de regularizar a superfície e eliminar quaisquer rugosidades causadas pelo acréscimo dos incrementos finais de resina.

\subsection{Experimentos}

Foi realizada a avaliação do efeito das soluções na resistência à tração dos anéis de borracha do sistema o'ring, sendo obtido ao final dos experimentos um gráfico correspondente às leituras realizadas. Após a obtenção dos valores iniciais (T0), os anéis foram imersos por 10 dias (T1) e sequencialmente foram submetidos às leituras e imersões até completar 90 dias simulados (T2 e T3). A Figura 8 esquematiza esta sequência.

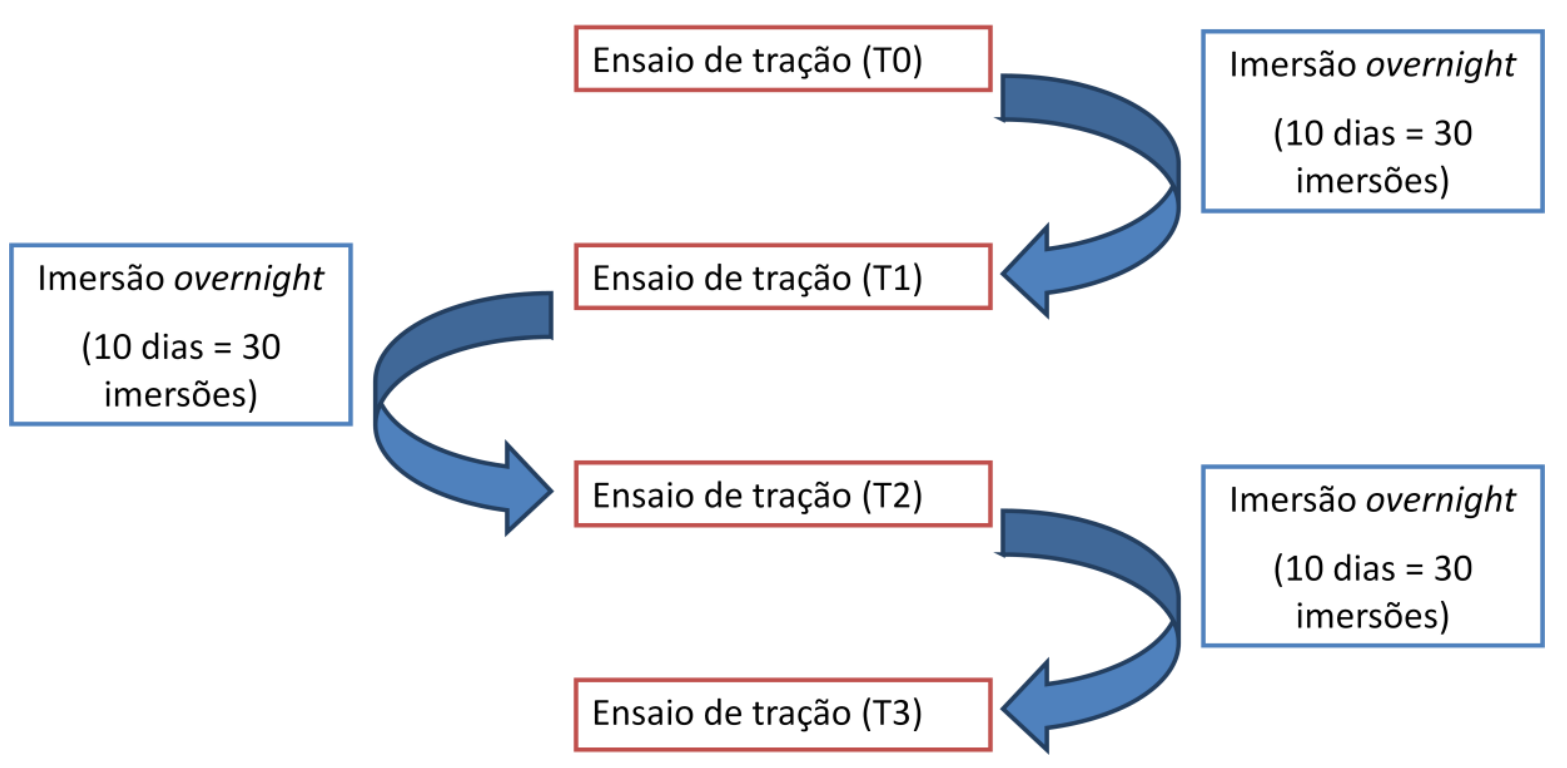

Figura 8: Sequência das leituras.

Para simular um período de 3 meses foi necessário realizar as três trocas de soluções por 30 dias consecutivos (30 dias experimentais $\times 3$ simulações diárias = 90 imersões pelo paciente/3 meses), sendo esta sequência interrompida a cada 10 dias para as leituras da resistência de tração. Os espécimes foram acondicionados em saliva artificial neste intervalo. 
As soluções com os corpos-de-prova foram armazenadas em estufa, à temperatura padronizada de $37^{\circ} \mathrm{C}$. Após cada imersão de 8 horas, os espécimes foram lavados com água deionizada de forma a prevenir a influência de possíveis íons, presentes em água corrente ou destilada, nos resultados obtidos.

As soluções foram utilizadas nas suas formas de apresentação comercial, com exceção do hipoclorito de sódio, que foi manipulada conforme descrição de Baranabé et al., 2004: $5 \mathrm{~mL}$ de hipoclorito de sódio 2,5\% para cada $200 \mathrm{~mL}$ de água deionizada. Desta forma foram definidos os seguintes grupos experimentais de imersão para os anéis de borracha:

a) Grupo 1: água deionizada (controle);

b) Grupo 2: enxaguatório à base de cloreto de cetilpiridínio (Cepacol 0,500 $\mathrm{mg} / \mathrm{mL})$;

c). Grupo 3: enxaguatório à base de óleos essenciais (Listerine);

d). Grupo 4: enxaguatório fluoretado (Cepacol Flúor);

e). Grupo 5: hipoclorito de sódio 0,05\%;

\subsection{Ensaios de resistência à tração}

Para os ensaios mecânicos foram utilizados os seis espécimes de cada grupo experimental e um destes foi selecionado aletoriamente para a leitura por microscopia eletrônica de varredura qualitativa.

Os ensaios foram realizados na máquina de ensaios mecânicos dotada de servoválvula MTS-810 (Material Testing System - MTS 810, Eden Prairie, Minneapolis, MN, EUA) equipada com o sistema de computador Flex Test 40, pertencente ao Laboratório de Ensaios Mecânicos do Departamento de Materiais Odontológicos e Prótese da Faculdade de Odontologia de Araraquara-UNESP (Figura 9) 


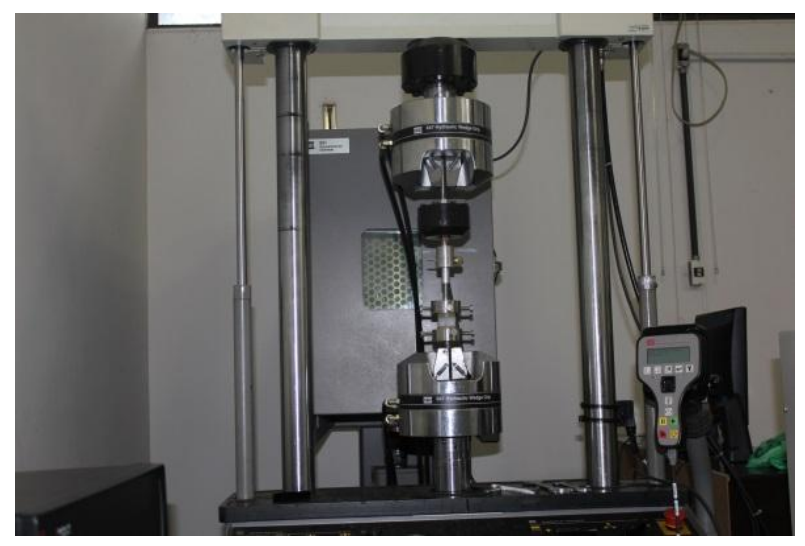

Figura 9: Máquina de ensaios mecânicos MTS-810

Para a adaptação das amostras na máquina de ensaios foi utilizado um dispositivo metálico de duas partes desenvolvido na Faculdade de Odontologia de Araraquara-UNESP. Cada uma das partes possui uma porção cilíndrica de $60 \mathrm{~mm}$ de diâmetro externo, $48 \mathrm{~mm}$ de diâmetro interno e $15 \mathrm{~mm}$ de altura, onde as amostras foram posicionadas e fixadas por meio de quatro parafusos localizados ao redor deste cilindro. Acoplados na porção inferior dos dispositivos foi colocado um suporte metálico cilíndrico de $12 \mathrm{~mm}$ de diâmetro por $47 \mathrm{~mm}$ de comprimento, que permitia a fixação dos dispositivos no mordente da máquina de ensaios (Figura 10).

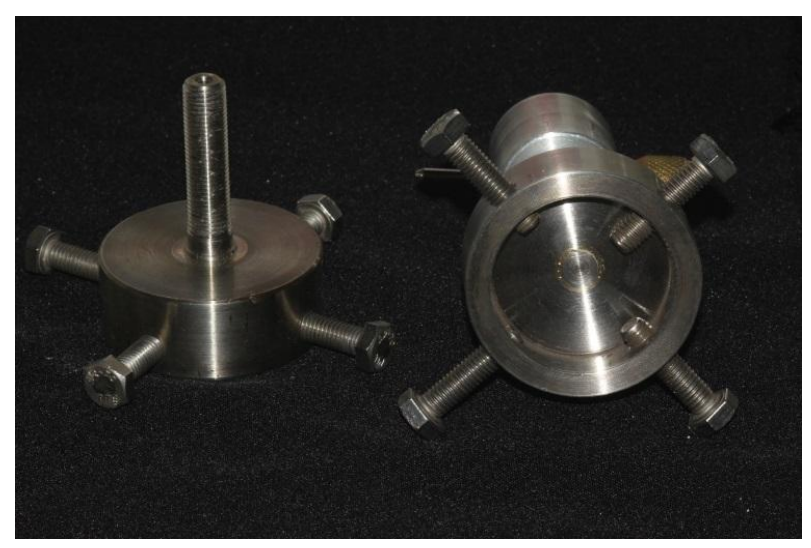

Figura 10: Dispositivos metálicos.

Após adaptação dos dispositivos e das amostras, a célula de carga (contendo a contra-base com as cápsulas) era lentamente rebaixada até encontrar a posição de fixação sobre a base, estando preparada para os ciclos de inserção e remoção. Foi utilizada a célula de carga de $2,5 \mathrm{kN}$ e velocidade constante de $1 \mathrm{~mm} \mathrm{~min}^{-1}$ (Figura 11). 


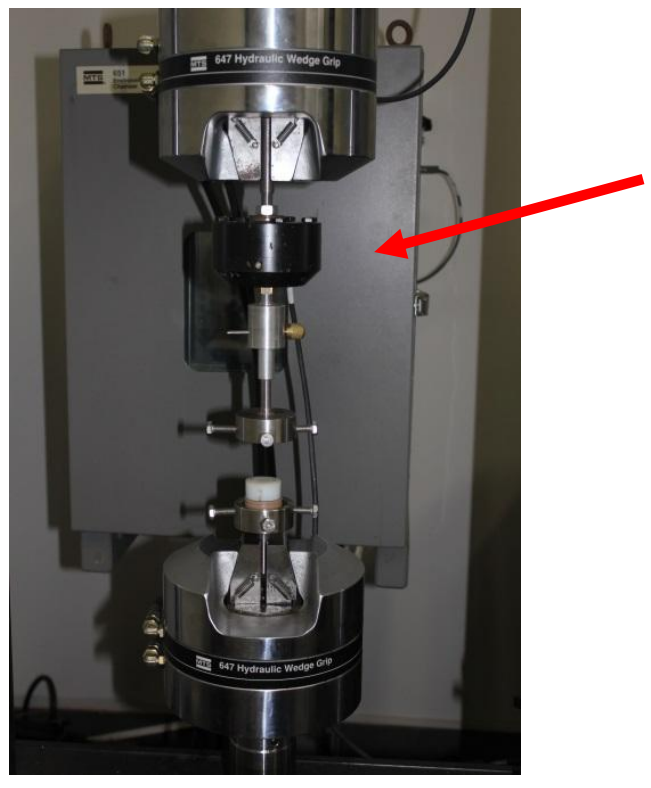

Figura 11: Dispositivos em posição na máquina de ensaios e célula de carga (seta).

Os valores da força de retenção dos anéis de borracha do sistema o'ring foram obtidos por meio do ensaio de resistência à tração, utilizando o software Test Works for Test Star - MTS 810 (Eden Prairie, Minneapolis, MN, EUA - Figura 12).

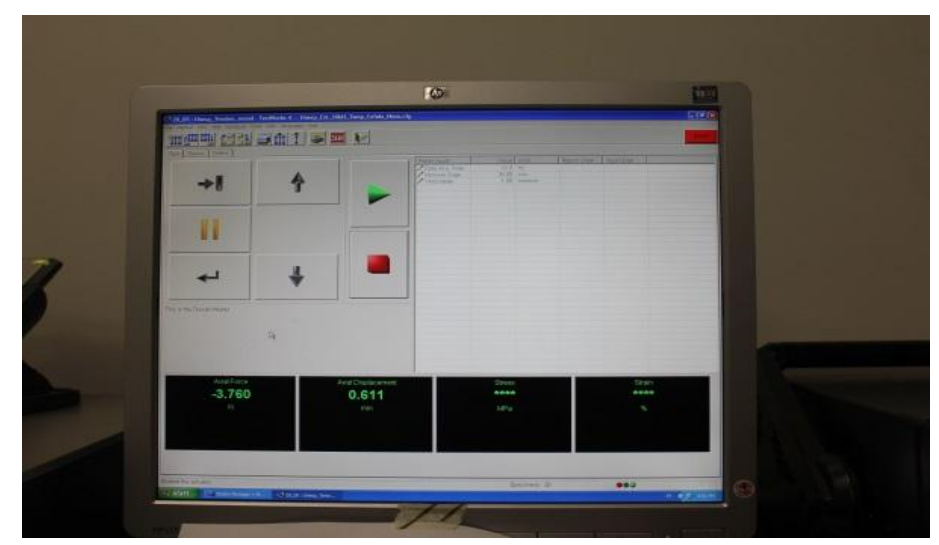

Figura 12: Software Test Works for Test Star

\subsection{Microscopia Eletrônica de Varredura}

Como citado anteriormente, após submetido ao ensaio de resistência a tração, um espécime de cada grupo foi analisado em Microscópio Eletrônico de Varredura (MEV) (EVO 50, Zeiss, Cambridge, Inglaterra) para avaliação qualitativa 
da superfície. A troca de energia entre o feixe de elétrons e a amostra resulta na emissão de elétrons e radiação eletromagnética, que pode ser detectada e produz uma imagem. Os espécimes foram submetidos ao processo de metalização (Metalizador Sputter Coater, Modelo: SCD 050, Bal-Tec, Lichtenstein). Uma cobertura ultrafina de material eletricamente condutiva (ouro) foi depositada para prevenir o acúmulo de campos elétricos estáticos no espécime devido à irradiação elétrica durante a produção da imagem. Outra razão para a metalização, mesmo quando há condução mais do que suficiente é melhorar o contraste. As leituras foram realizadas no Laboratório de Microscopia Eletrônica de Varredura do Departamento de Química, da Faculdade de Filosofia, Ciências e Letras de Ribeirão Preto da Universidade de São Paulo.

\subsection{Análise Estatística}

Após realização dos ensaios, os dados obtidos da força de retenção $(N)$ foram registrados e submetidos à Análise de Variância (ANOVA) e teste de Bonferroni $(\alpha=0,05)$. 
5 Resultados 


\subsection{Ensaio de resistência à tração dos o'rings}

Os dados utilizados consistiram de valores numéricos equivalentes à resistência à tração $(\mathrm{N})$ para cada anel de borracha. Foram provenientes do cruzamento de quatro tempos (inicial, 30 dias, 60 dias e 90 dias) e cinco soluções (Água deionizada, Cepacol, Listerine, Cepacol Flúor e Hipoclorito de sódio 0,05\%) e seis repetições. A amostra do experimento foi composta por 30 espécimes que foram divididos em 5 grupos experimentais (Apêndice A p. 128).

A análise estatística foi realizada por meio do programa SPSS 17.0 (SPSS Inc., Chicago, IL, EUA). A análise do conjunto de resultados obtidos nos testes preliminares levou à conclusão de que a distribuição amostral dos dados era normal (Apêndice B, p. 129). Foi utilizado o modelo linear de efeitos mistos (efeitos aleatórios e fixos) que é utilizado na análise de dados onde as respostas de um mesmo corpo-de-prova estão agrupadas e a suposição de independência entre as observações num mesmo grupo não é adequada. Os resultados do teste estão expressos na Tabela 2.

Tabela 2. Resultados da Análise de Variância.

\begin{tabular}{cccccc}
\hline $\begin{array}{c}\text { Fonte de } \\
\text { Variação }\end{array}$ & $\begin{array}{c}\text { Soma de } \\
\text { Quadrados Médios }\end{array}$ & $\begin{array}{c}\text { Graus de } \\
\text { Liberdade }\end{array}$ & $\begin{array}{c}\text { Quadrados } \\
\text { Médios }\end{array}$ & $\begin{array}{c}\text { Valor } \\
\text { de F }\end{array}$ & $\begin{array}{c}\text { Valor } \\
\text { de P }\end{array}$ \\
\hline Entre tempos & 145,1983 & 3 & 48,3994 & 53,20 & 0,0001 \\
Resíduo I & 18,1958 & 20 & 0,9098 & & \\
Entre soluções & 228,6361 & 4 & 57,1590 & 56,92 & 0,0000 \\
Interação tempos e & & & & & \\
soluções & 46,3121 & 12 & 3,8593 & 3,84 & 0,0245 \\
Resíduo II & 80,3383 & 80 & 1,0042 & & \\
Variação Total & 518,6807 & 119 & & & \\
\hline
\end{tabular}

A Análise de Variância indicou diferença estatisticamente significante para os fatores de variação tempo $(P=0,0001)$ e solução $(P=0,000)$. Para indicar estas diferenças foi realizado o teste de Bonferroni para comparações múltiplas 
(Apêndices C e D, p. 131 e 132). As médias e desvios-padrão destes fatores estão presentes nas Tabelas 3 e 4.

Tabela 3. Médias amostrais calculadas para o fator de variação: tempo.

\begin{tabular}{lcc}
\hline Fator de variação: tratamento & Médias $(\mathrm{MPa})$ & Desvio Padrão \\
\hline T0 & $11,25^{\mathrm{a}}$ & 1,38 \\
T1 & $9,63^{\mathrm{b}}$ & 1,74 \\
T2 & $8,76^{\mathrm{c}}$ & 2,06 \\
a,b,c & $8,40^{\mathrm{c}}$ & 1,93 \\
\cline { 2 - 2 } & Grupos com letras diferentes são estatisticamente diferentes $(P<0,05)$.
\end{tabular}

Tabela 4. Médias amostrais calculadas para o fator de variação: solução.

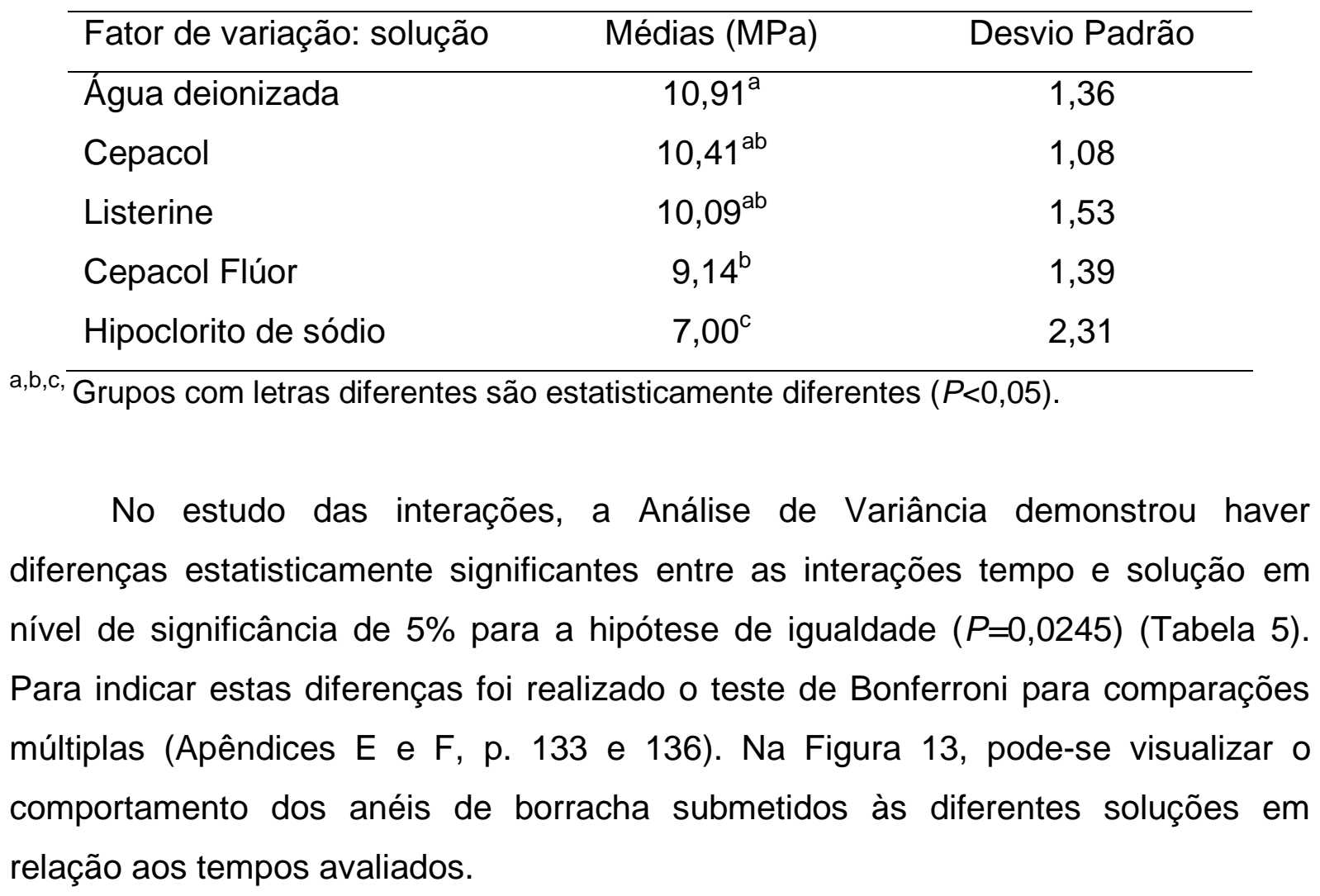


Tabela 5. Médias amostrais calculadas para a interação solução x tempo.

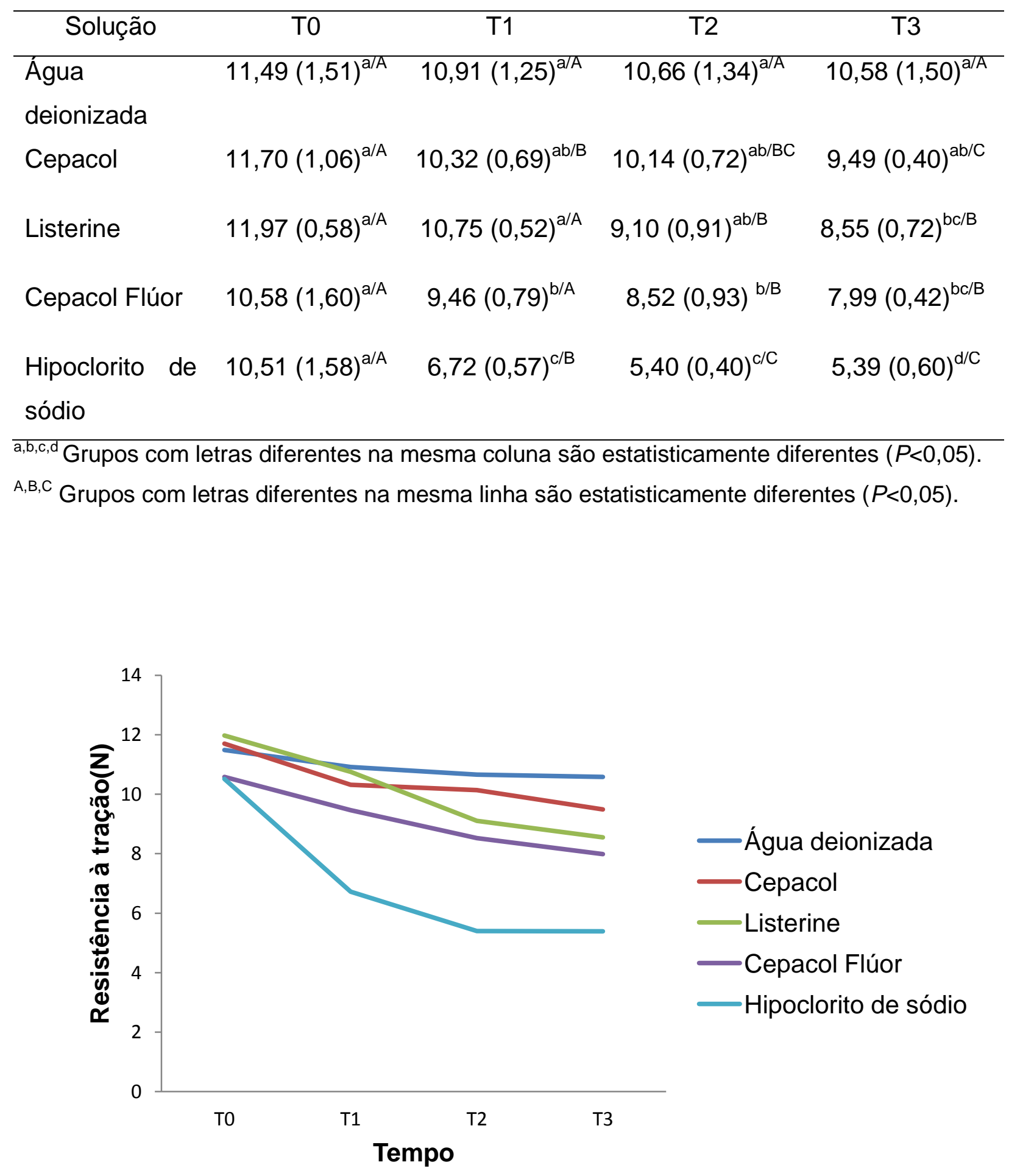

Figura 13: Interação solução $x$ tempo: comportamento dos anéis de borracha submetidos às diferentes soluções em relação aos tempos avaliados. 


\subsection{Análise qualitativa pontual dos o'rings pela microscopia eletrônica de varredura (MEV)}

Após uma visão generalizada dos o'rings, áreas com alterações de superfície identificadas por microscopia eletrônica de varredura (MEV) foram selecionadas e avaliadas com maior ampliação (20, 50, 100, 300 e 1000 vezes).

A Figura 14 representa o grupo controle, que foi submetido à imersão em água deionizada. É possível notar o acabamento superficial realizado pelos instrumentais de confecção e manutenção das propriedades originais do material (nitrilo) e a contaminação por material orgânico, como poeira, que pode ter sido incluída no momento da metalização.

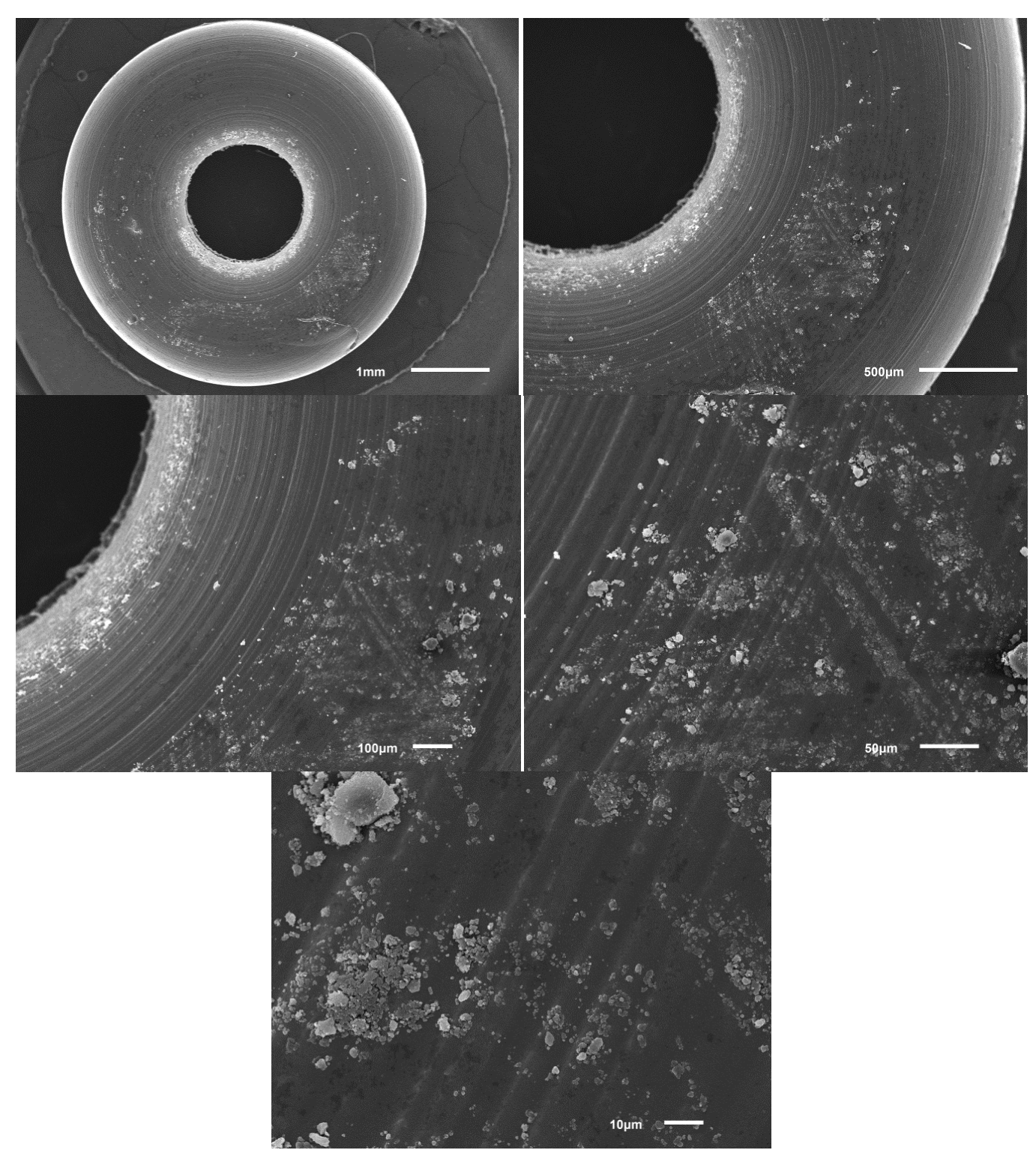

Figura 14: Grupo controle - imersão em água deioizada. 
A Figura 15 representa o grupo Cepacol, que foi submetido à imersão em cloreto cetilpiridínio $0,500 \mathrm{mg}$. Pelas imagens geradas, é possível observar a preservação do material do anel, com a presença em alguns pontos de contaminação, muito similares ao grupo da água deionizada.

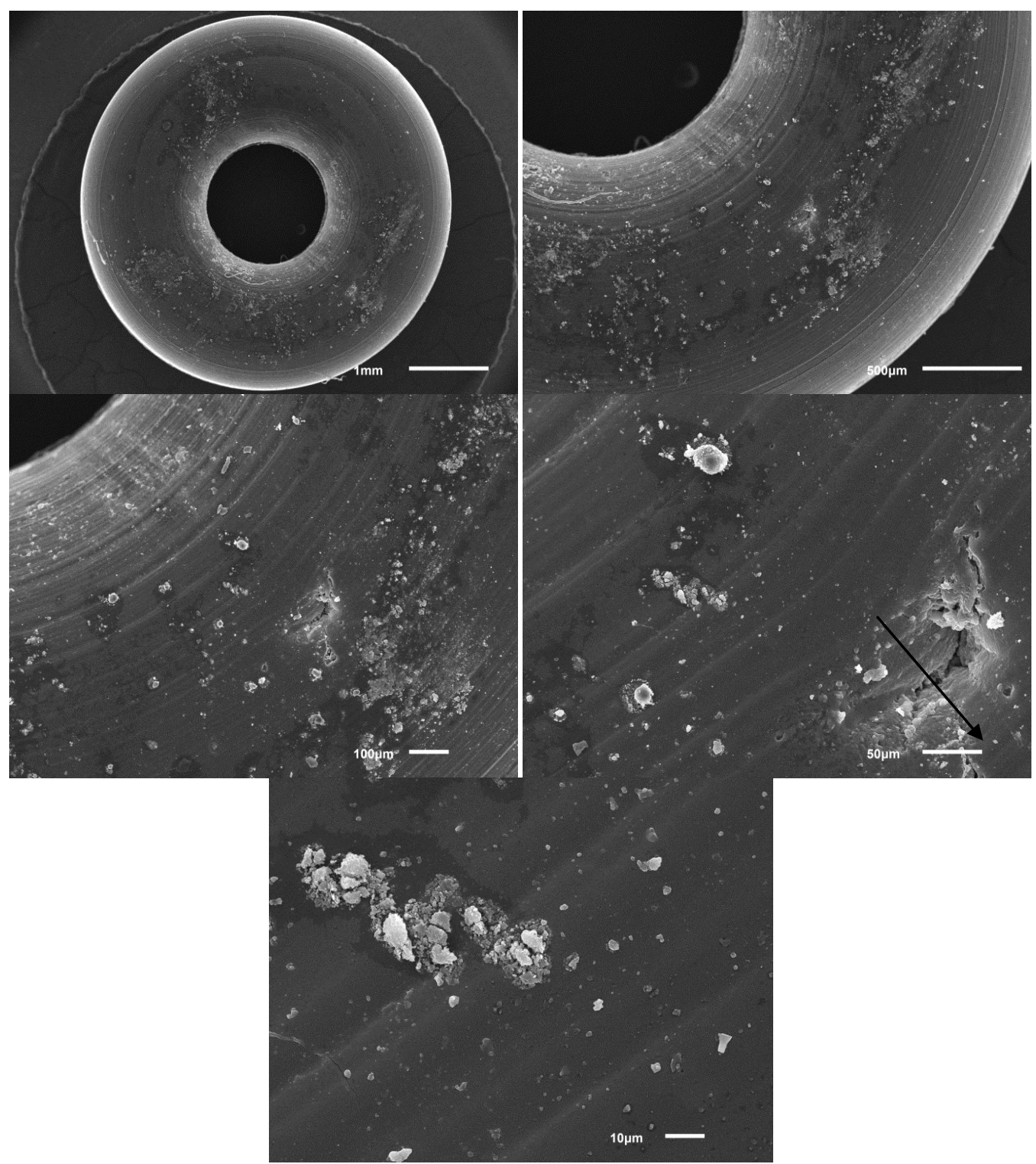

Figura 15: Grupo Cepacol - Precipitados distribuídos por toda a amostra, mas sem solução de continuidade do material. A flecha sinaliza o orifício criado pelo explorador utilizado para remover o anel 
A Figura 16 representa o grupo Cepacol Flúor, que foi submetido à imersão em cloreto cetilpiridínio $0,500 \mathrm{mg}$ com fluoreto de sódio. Observa-se a formação de uma película que envolve todo o espécime, com precipitados cristalinos.

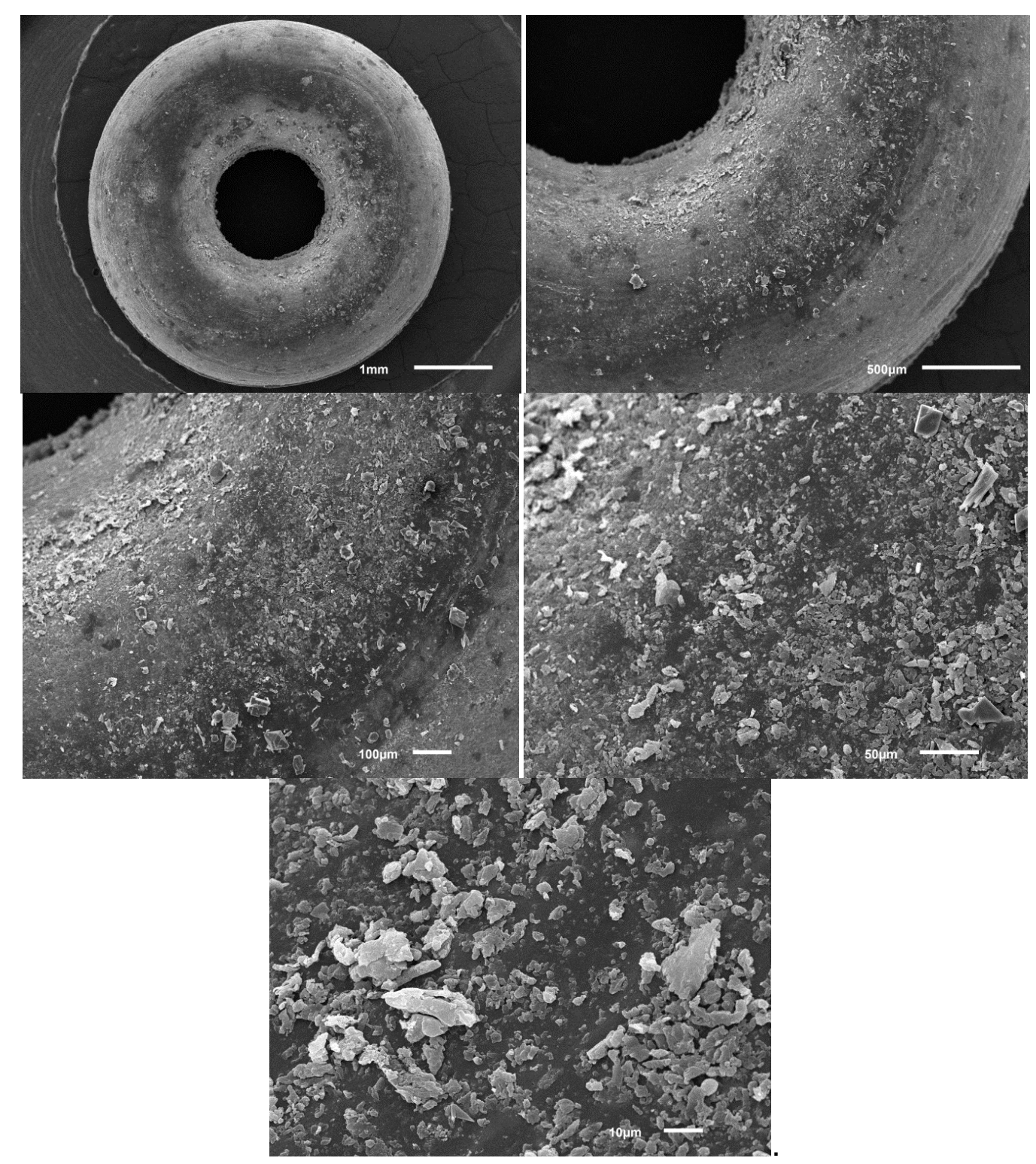

Figura 16: Grupo Cepacol Flúor - Precipitado distribuídos por toda a amostra de forma intensa formando uma película aderida por todo o espécime 
A Figura 17 representa o grupo Listerine. Avaliando 0 aspecto nas eletromicrografias, observa-se preservação das características originais do espécime, sem danos ou rompimento do nitrilo.

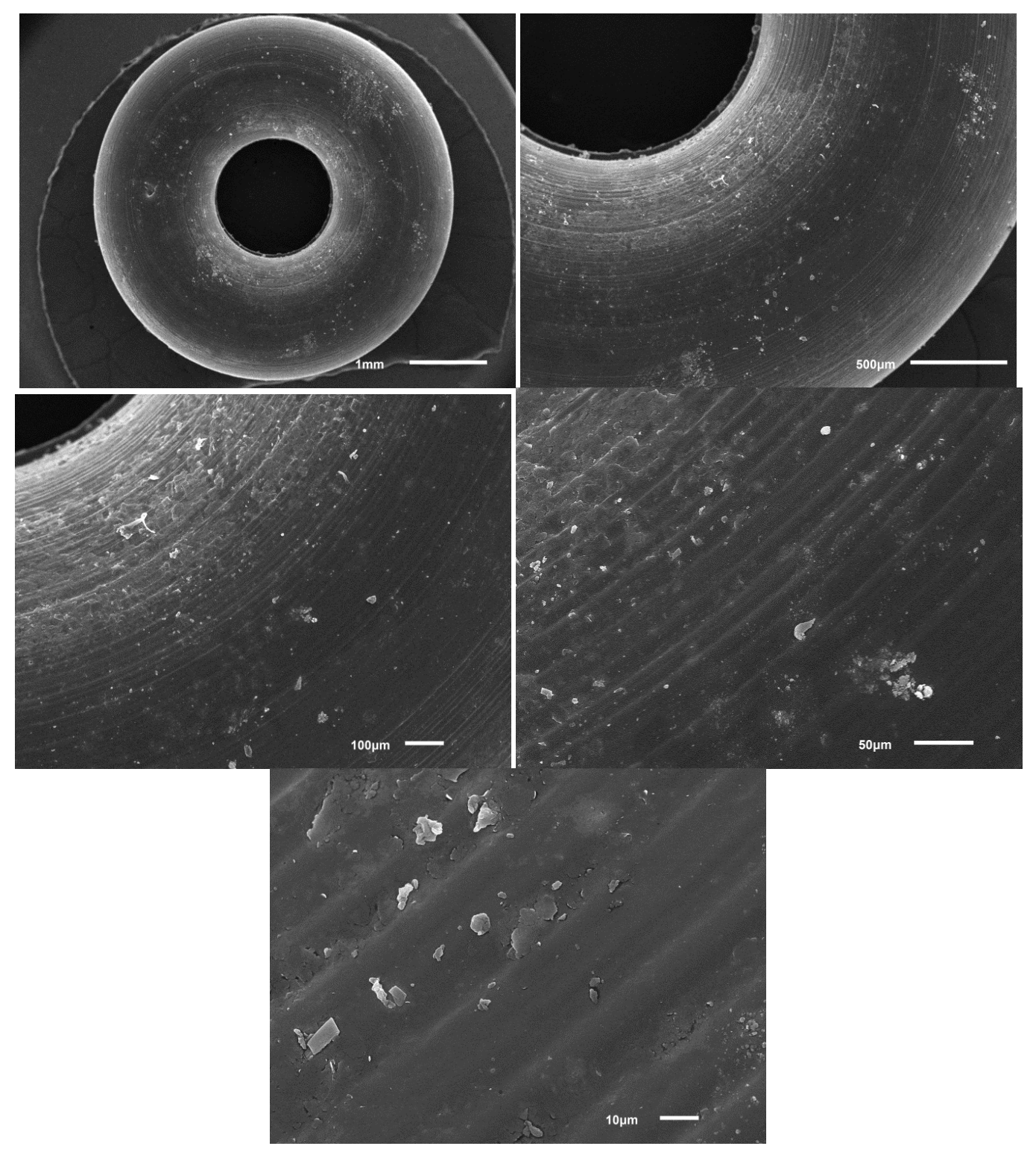

Figura 17: Grupo Listerine - Presevação da morfologia do material por toda a extensão do espécime. 
A Figura 18 representa o grupo hipoclorito de sódio, que foi submetido a imersão em solução com concentração de $0,05 \%$. Neste caso, houve ruptura do material em toda sua extensão, podendo ser inclusive percebida deformação dimensional no diâmetro do orifício, com diminuição da luz do mesmo.

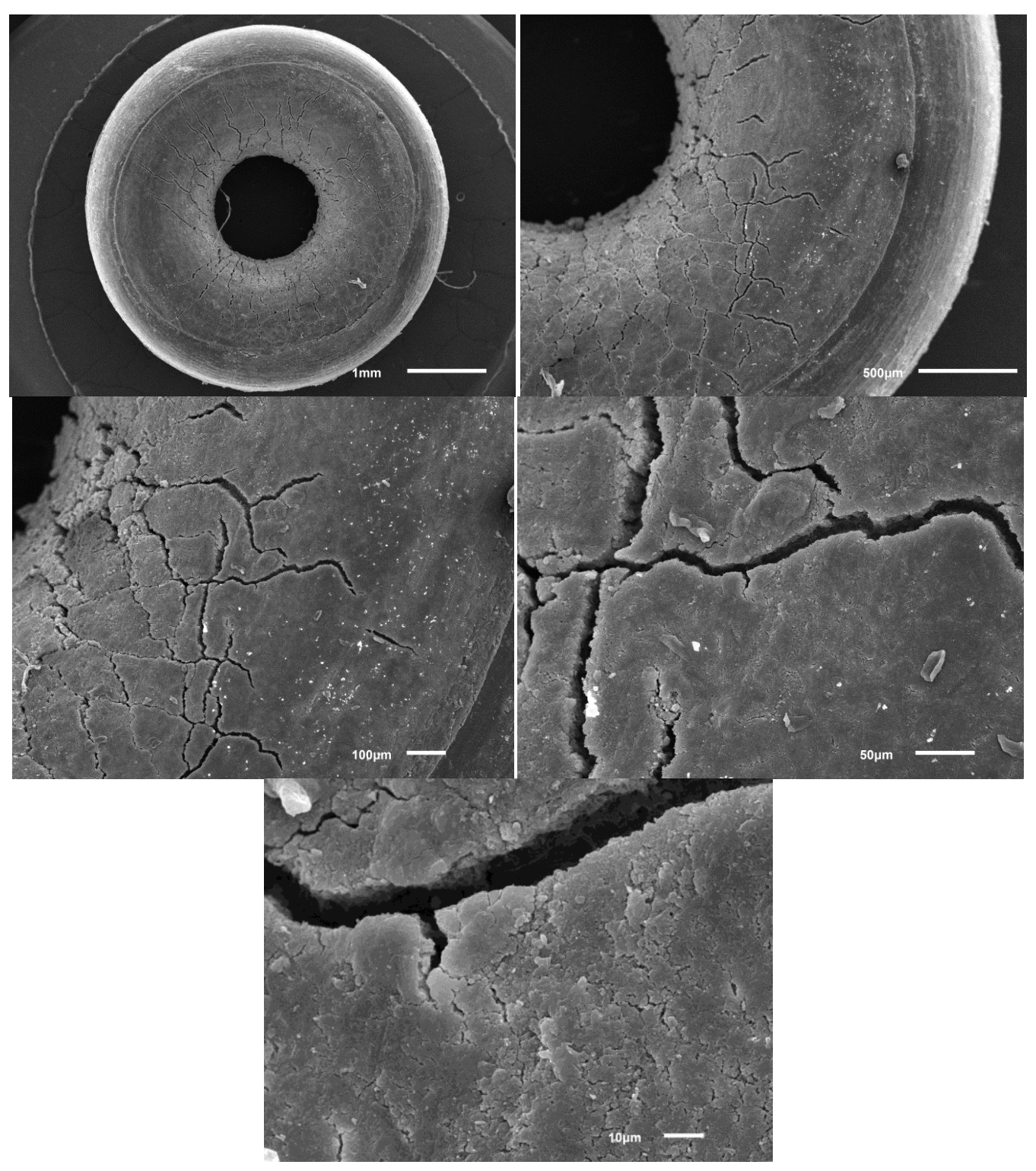

Figura 18: Grupo hipoclorito de sódio 0,05\% - Rupturas por todo o espécime. 


\section{Díscussão}


Como tem sido amplamente relatado na literatura, os higienizadores químicos apresentam grande eficácia sobre o biofilme de próteses (SEXSON, PHILLIPS, 1951; SMITH, 1961; SMITH, 1966; MACCALLUM et al., 1968; NEILL, 1968; ASHTON, BLOCH, 1971; ABERE, 1979; BUDTZ-JØRGENSEN, 1979; ABELSON, 1981; KEMPLER et al., 1982; COUNCIL ON DENTAL MATERIALS, INSTRUMENTS AND EQUIPMENT, 1983; DE PAOLA, MINAH, ELIAS, 1984; COUNCIL ON DENTAL THERAPEUTICS AND COUNCIL ON PROSTHETIC SERVICES AND DENTAL LABORATORY RELATIONS,1985; LEE et al., 1985; ABELSON, 1985; PARANHOS, MALACHIAS, PARDINI, 1991; JAGGER, HARRISON, 1995; WEBB et al., 1995 SESMA et al., 1999; SHEEN, HARRISON, 2000; BARNABÉ et al., 2004; GARCIA et al., 2004; BERGER, EWOLDSEN, 2006; PARANHOS et al., 2007, WATANABE et al., 2008; PINTO et al., 2008; NALBANT et al., 2008; BUERGERS et al., 2008; HONG et al., 2009; RIBEIRO et al., 2009; FERREIRA et al., 2009, PARANHOS et al., 2009; MONTAGNER et al., 2009; SOUZA et al., 2009; VIEIRA et al., 2010; ULUDAMAR et al., 2010; RAMAGE et al., 2011; FELTON et. al., 2011; FELIPUCCI et al., 2011 a e b; ANDRÉ et al., 2011; DAVI et al, 2012; DHAMANDE et al., 2012). Em relação à ação antimicrobiana, são apresentados estudos laboratoriais (in vitro) e clínicos (in vivo). De acordo com os trabalhos, observa-se que ainda não há na literatura um consenso de qual produto químico é o mais adequado para higienização de próteses totais. Os trabalhos clínicos, visando a comparação da eficácia de soluções químicas, principalmente peróxidos e hipocloritos, mostram resultados variados. Os estudos laboratoriais, extremamente importantes para a avaliação das propriedades de tais produtos, também têm sido conduzidos objetivando análise da efetividade e efeitos adversos antes que sejam testados clinicamente e comercializados; porém, os resultados também não são conclusivos.

Neste estudo foi avaliado o efeito de soluções higienizadoras de fácil acesso ao paciente, os enxaguatórios bucais Cepacol Tradicional, Cepacol Flúor, Listerine e solução caseira à base de hipoclorito de sódio $0,05 \%$, preconizada por Barnabé et al, em 2004. Os autores sugeriram essa menor concentração porque verificaram efeito antimicrobiano para higienização de próteses totais acrílicas após a escovação com sabão de coco. Esta solução também já foi utilizada nos estudos de Felipucci et al. (2011a, 2011b) e Davi et al, (2012), que avaliaram seu efeito em ligas metálicas alternativas. De acordo com os autores, já nessa concentração o 
hipoclorito de sódio foi capaz de provocar manchamento e sinais de corrosão. Foi também incluída a água deionizada no estudo, visando obtenção de um grupo controle que não apresentasse nenhuma interferência devido à liberação de íons, causada pelo uso de água corrente ou destilada (FELIPUCCI et al., 2011a; FELIPUCCI et al., 2011b).

As soluções utilizadas são classificadas como de fácil acesso ao paciente e têm ação antimicrobiana descrita na literatura (DE PAOLA, MINAH, ELIAS, 1984; WALKER, 1988; NIKAWA et al., 1999; SHAY, 2000; KEYF, GÜNGÖR, 2003; LESSA et al., 2007; WATANABE et al., 2008; ANDRÉ et al., 2011). As imersões foram realizadas com o intuito de simular um período overnight por 3 meses, com trocas a cada 8 horas, totalizando 960 horas (120 dias $\times 8$ horas diárias $=960$ horas), tais como foram utilizadas em outros estudos (NGUYEN et al., 2010; FELIPUCCI et al., 2011a; FELIPUCCI et al., 2011b, YOU et al., 2011). As soluções com os corpos-deprova foram armazenadas em estufa, à temperatura padronizada de $37^{\circ} \mathrm{C}$. Após cada imersão de 8 horas, os espécimes também foram lavados com água deionizada de forma a prevenir a influência dos possíveis íons.

Como citado anteriormente, a mucosa oral de usuários de aparelhos protéticos apresenta uma colonização bacteriana específica, sendo observada, com frequência, a presença da patologia conhecida como candidíase atrófica crônica ou estomatite protética (VAN REENEN, 1973; BUDTZ-JØRGENSEN et al., 1975; CATALAN et al., 1977; ANDRUP et al., 1977; VANDENBUSSCHE, SWINE, 1984; FOUCHE, SLABBERT, COOGAN, 1986; THEILADE, BUDTZ-JØRGENSEN, 1988; NIKAWA et al., 1998; KULAK-OSKAN, KAZAZOGLU, ARIKAN, 2002; EMAMI et al., 2012). Uma das orientações mais frequentemente dadas pelos profissionais para minimizar a ocorrência desta patologia é a da retirada da prótese dentária no período noturno, também conhecido como período overnight, que compreende a média de 8 horas. Durante este período, autores sugerem a colocação do aparelho em soluções, sejam elas higienizadoras ou até mesmo água (DEVLIN, BEDI, 1988; KULAK et al., 1997; WALBER, RADOS, 2000; BARBEAU et al., 2003). Desta forma, encontram-se na literatura diversas metodologias que simulam este período de imersão de 8 horas (overnight), o qual foi adotado no presente estudo (NEIL, 1968; BACKENSTOSE, WELLS, 1977; UNLÜ et al., 1996; KULAK et al., 1997; NIKAWA et al., 2003; SATO et al., 2005; PINTO et al., 2008; NGUYEN et al., 2010; FELIPUCCI 
et al., 2011a; FELIPUCCI et al., 2011b, DAVI et al. 2012). Porém, quando avaliada a efetividade na remoção do biofilme, alguns pesquisadores observaram que se fosse utilizada apenas a imersão, a efetividade era menor que a escovação feita de maneira isolada (BERGER, EWOLDSEN, 2006; PARANHOS et al., 2007). Deste modo, é fundamental que seja indicado um protocolo de higienização que associe métodos, que seja eficiente e de fácil utilização para os usuários de próteses removíveis (FERRAN et al., 1984; NIKAWA et al., 1999; SESMA et al., 1999; SHAY, 2000; PARANHOS et al., 2007; SOUZA et al. 2009).

A força de retenção proporcionada pelos sistemas de encaixe para overdentures implanto-retidas é de fundamental importância para o sucesso do tratamento reabilitador, para a satisfação do paciente no que diz respeito à estabilidade da prótese durante a função, além da estética e fonética (EPSTEIN et al., 1999; VAN DER BILT et al., 2010; RUTKUNAS et al., 2011). O sistema de encaixe do tipo bola (o'ring) é amplamente utilizado pelos profissionais no caso da aplicação de dois implantes mandibulares, por serem encaixes resilientes, permitirem movimentação da prótese e por distribuírem as forças mastigatórias entre as estruturas de suporte (PETROPOULOS, MANTE, 2011; MACHADO et al., 2011; BURNS et al., 2011; FATALLA et al., 2012; SUZUKI, OHKUBO, KURTZ, 2013), diminuindo a carga sobre os pilares na ordem de 75 a $85 \%$ (RIGDON, 1996).

A retenção das overdentures está diretamente relacionada com as forças verticais e torsionais recebidas, ou seja, com a resistência da prótese à força de separação de sua posição de assentamento. A estabilidade deste tipo de prótese se refere à sua manutenção em posição devido à resistência às forças oblíquas e ântero-posteriores (TABATABAIAN, ALAIE, SEYEDAN, 2010; SUZUKI, OHKUBO, KURTZ, 2013). Observam-se na literatura trabalhos científicos relacionados à retenção das próteses fixadas por meio de attachments do tipo barra/clip e sistemas de encaixe o'ring. As discussões se baseiam nos valores de retenção quando ciclos de inserção e remoção do conjunto são simulados. Clinicamente e em estudos in vitro, observam-se desgaste e necessidade de trocas contínuas do anel de borracha, que propicia resiliência e retenção à cápsula sobre o encaixe bola (WICHMANN, KUNTZE, 1999; EPSTEIN et al., 1999; BOTEGA et al.,2004; NAERT, ALSAAD, QUIRYNEN, 2004; KARABUDA, YALTIRIK, BAYRAKTAR, 2008; BAYER et al., 2009; RODRIGUES et al., 2009; VAN DER BILT et al., 2010; NGUYEN et al., 2010; 
RUTKUNAS et al., 2011; BILHAN et al., 2011). Apesar de alguns autores relatarem que o uso do tipo barra/clipe é mais favorável (WALTON, 2003, KARABUDA, YALTIRIK, BAYRAKTAR, 2008), a distribuição de cargas ao redor dos implantes se mostra mais favorável no tipo o'ring e os pacientes relatam preferência a este tipo de reabilitação (NAERT, ALSAAD, QUIRYNEN, 2004; BARÃO et al., 2009; BURNS et al., 2011).

Neste estudo, optou-se pela avaliação dos encaixes do tipo o'ring por serem muito utilizados pelos profissionais e devido ao grande número de citações na literatura a respeito do seu desempenho mecânico (WICHMANN, KUNTZE, 1999; EPSTEIN et al., 1999; BOTEGA et al.,2004; NAERT, ALSAAD, QUIRYNEN, 2004; KARABUDA, YALTIRIK, BAYRAKTAR, 2008; BAYER et al., 2009; RODRIGUES et al., 2009; BARÃO et al., 2009; VAN DER BILT et al., 2010; PETROPOULOS, MANTE, 2011; RUTKUNAS et al., 2011; BILHAN et al., 2011; BURNS et al., 2011; YANG et al., 2011; SUZUKI, OHKUBO, KURTZ, 2013). Houve todo cuidado em relação à padronização dos movimentos de inserção e remoção dos componentes desse encaixe no sentido do longo eixo do implante, de forma a se avaliar exatamente o comportamento destes encaixes submetidos à imersão nas soluções, uma vez que foi constatada na literatura a influência da inclinação do pilar como fator que potencializa o desgaste do sistema (SAAVEDRA et al., 2007; RODRIGUES et al., 2009; YANG et al., 2011).

Muito se discute a respeito da quantidade mínima de força de retenção que um sistema de encaixe deve apresentar. Caldwell (1964) apud Rodrigues et al. (2009) relatou que a força necessária para manter a overdenture em posição durante a mastigação foi de 15 a $20 \mathrm{~N}$ para a mastigação de alimentos mais pegajosos e de $10 \mathrm{~N}$ para a mastigação de alimentos corriqueiros. Lehmann e Arnim (1978) discutiram que a retenção ideal de um encaixe deveria ser de 10 a $15 \mathrm{~N}$, entretanto afirmaram que a retenção mínima deveria ser de 5 a $7 \mathrm{~N}$ por encaixe e, para evitar danos ao tecido mole e ósseo adjacentes, a retenção por encaixe não deveria exceder $10 \mathrm{~N}$. No presente trabalho, a média de retenção obtida no T0 apresentou-se acima deste valor $(11,25 \mathrm{~N})$. Entretanto após 30 dias, a retenção tendeu a cair progressivamente até os 90 dias que foram avaliados (Tabela 3, p. 91). 
De acordo com os resultados obtidos, quando analisado o fator de variação tempo, houve diferença estatisticamente significante entre o tempo inicial, antes dos anéis serem ensaiados com os demais tempos, após 30, 60 e 90 dias (Tabela 3, p. 91). Entre T1 e T2 houve também houve diferença significante, entretanto, entre $o$ T2 (60 dias) e T3 (90 dias) não houve diferença significante (Tabela 3, p. 91). Apesar de ter ocorrido diminuição da retenção em função do tempo, todos os valores obtidos estão acima do valor entre 5 e $7 \mathrm{~N}$, preconizado por Lehmann e Arnim (1978) para este tipo de encaixe.

Quando foi analisado o fator solução, a água deionizada (controle) propiciou obtenção de maior resistência à tração aos anéis de borracha que o Cepacol Flúor e o hipoclorito de sódio. O Cepacol e Listerine não apresentaram diferenças em relação ao controle e entre si, entretanto houve diferença entre o Cepacol Flúor e o hipoclorito de sódio (Tabela 4, p. 91). O hipoclorito de sódio apresentou diferença estatisticamente significante em relação aos demais grupos, tendo propiciado a menor resistência à tração que as demais soluções avaliadas.

Em relação ao Listerine, os resultados demonstraram leve diminuição da retenção. Alguns estudos, como o de You et al. (2011), relataram inclusive aumento da retenção quando esta solução foi utilizada para higienização de overdentures, sugerindo a sua indicação na rotina da higienização. Nguyen et al., em 2010, também demonstraram que o Listerine aumentou a retenção do encaixe Locator quando comparado com o grupo controle.

Quanto ao Cepacol, nenhum estudo avaliou seu uso associado a encaixes de overdentures. Ito et al., (1985) e Lessa et al., (2007), demonstraram seu efeito antimicrobiano e estudos preliminares de Felipucci et al. (2011a e 2011b) demonstraram que esta solução não apresentou nenhum efeito deletério em relação à resina termopolimerízável e ligas de cobalto-cromo. Neste estudo, também não apresentou nenhum efeito deletério ao sistema de retenção, tendo propiciado retenção mais baixa que a inicial, entretanto sem significado estatístico. Além disso, não apresentou diferença em relação ao grupo controle (água deionizada), mesmo após os 90 dias de avaliação. Desta forma, pode-se pensar na sua indicação para auxiliar na higienização diária das overdentures. Eletromicrografias foram obtidas por meio de Microscocopia Eletrônica de Varredura (MEV) como forma de esclarecer 
os resultados de força de retenção obtidos. No grupo controle, que foi submetido à imersão em água deionizada, de acordo com a análise topográfica qualitativa, não foram detectadas alterações estruturais do nitrilo, bem como no grupo do Cepacol. No grupo do Listerine, indícios de ressecamento puderam ser observados sem, entretanto, haver solução de continuidade do material. Já nos grupos do Cepacol Flúor e hipoclorito de sódio foram visualizadasalterações significativas.

Quando avaliado o Cepacol com flúor, houve redução da retenção dos anéis em relação ao grupo controle e maior retenção do que o grupo do hipoclorito de sódio. Nas imagens de contraste topográfico, foi verificada a presença de uma película envolvendo todo o anel, com precipitado cristalino considerável, o que pode ter influência, possivelmente como fator lubrificante, na diminuição da retenção. Não há relatos na literatura associando esta solução à resistência de retenção de sistemas de encaixes. Como discutido anteriormente, a redução da retenção está associada à abrasão do anel, o que pode também nesse caso, estar associado ao efeito do flúor, da composição do enxaguatório, nos metais componentes da cápsula e do titânio do pilar, que pode ter ocasionado desprendimento de íons destes materiais (FAIS et al., 2012; TONIOLLO et al., 2012). Fais et al., em 2012, estudaram o efeito do fluoreto de sódio na rugosidade do Ti cp e liga de Ti-6Al-4V. Os autores pontuaram a ação do flúor em contato com este material, sugerindo que a presença de flúor nos dentifrícios e enxaguatórios bucais pode causar efeitos deletérios na superfície dos metais. Os íons fluoretos podem diminuir a resistência destes materiais, deixando-os propensos à corrosão. Neste estudo foi avaliado somente o anel de nitrilo, no entanto, é possível que o flúor tenha afetado também este material, uma vez que houve redução significativa da retenção após 60 dias. Análises futuras deste precipitado por meio da análise qualitativa pontual por energia dispersiva por raios-X (EDS) poderão elucidar a constituição dos cristais.

Os resultados encontrados para o grupo do hipoclorito de sódio se assemelham aos achados de Nguyen et al. (2010) que demonstraram que o hipoclorito de sódio (6,15\% diluído na proporção 1:10) propiciou acentuada perda de retenção, além de causar amolecimento e branqueamento do encaixe Locator. You et al. (2011) também avaliaram o efeito de soluções higienizadoras, dentre elas o hipoclorito de sódio $(6,15 \%$ diluídos na proporção 1:10) e, seu uso, da mesma forma, causou diminuição significativa de retenção no encaixe Locator. Varghese et al, em 
2007, também estudaram o efeito de higienizadores, somente por meio de tração, sem a realização de ciclagem, na retenção de outro tipo de sistema (clipe de Hader para overdentures). De acordo com os resultados obtidos, a imersão em solução de hipoclorito de sódio (5,25\% na diluição de 1:10), pelo tempo de 15 minutos, aumentou a retenção. Estes resultados foram contrários ao encontrados no presente estudo, entretanto esta constatação não foi positiva, pois, segundo os autores, ocorreu em detrimento do material do clipe. Além disso, a concentração do hipoclorito de sódio foi maior que a do presente estudo e a composição do material avaliado era diferente. Quando analisadas as imagens de contraste topográfico do grupo do hipoclorito de sódio, pode-se verificar que houve solução de continuidade do o'ring em toda sua extensão (rachaduras), gerando deformação dimensional significativa no diâmetro do orifício do anel.

$\mathrm{Na}$ análise das interações, houve diferença estatisticamente significante quando comparadas a resistência à tração inicial com a final, em todas as soluções, com exceção do grupo controle (água deionizada). No Cepacol e no hipoclorito de sódio a retenção diminuiu significativamente a partir de 30 dias. No Listerine e Cepacol Flúor, a diminuição da retenção ocorreu após 60 dias de experimento.

$\mathrm{Na}$ cápsula de retenção utilizada neste estudo, há um anel retentivo que apresenta diâmetro de $1,5 \mathrm{~mm}$ e é composto por um material denominado nitrilo (rubber nitryl), cujas características são: alta resistência ao desgaste, à força compressiva e à corrosão (BOTEGA et al., 2004). Desta forma, é muito provável que somente o anel retentivo não seja responsável pela diferença de valores de retenção, ou seja, as soluções apresentaram efeito deletério nos anéis de borracha avaliados. $O$ fabricante desses anéis indicam sua substituição a cada 6 meses, 0 que alguns estudos também discutem, enfatizando a necessidade de proservação do caso em reabilitações orais que empregam esses encaixes (SAAVEDRA et al., 2007; VARGHESE et al., 2007, NGUYEN et al., em 2010; YOU et al., 2011). Neste estudo, foram avaliados 3 meses de imersão, que de acordo com os resultados, foi um período já suficiente para diminuir significativamente a retenção dos conjuntos. Entretanto, esses resultados não coincidem com os obtidos por van Kampen et al. (2003), quando avaliaram clinicamente a retenção também por 3 meses, embora, sem terem utilizados soluções complementares de higienização. 
Alguns estudos que avaliaram a retenção, associados à ciclagem, relataram aumento dos valores de retenção devido à deteriorização dos anéis (BOTEGA et al., 2004; VARGHESE et al., 2007; NGUYEN et al., 2010; YOU et al., 2011). No entanto, não existe um comportamento padrão, uma vez que outros, ou até os mesmos estudos, relataram diminuição da retenção em alguns grupos experimentais, assim como foi encontrado no presente trabalho (WICHMANN, KUNTZE, 1999; BONACHELA et al., 2003; KARABUDA, YALTIRIK, BAYRAKTAR, 2008; BAYER et al., 2009; RODRIGUES et al., 2009; TABATABAIAN, ALAIE, SEYEDAN, 2010; NGUYEN et al., 2010). Segundo a literatura, a abrasão é responsável pelo aumento no diâmetro dos anéis retentivos, propiciando diminuição dos valores de retenção (BOTEGA et al., 2004). Também é provável que a perda de retenção ocorra devido à dilaceração do anel, como foi verificado claramente pela presença de rupturas nas eletromicrografias deste grupo. Entretanto, de acordo com Botega et al. (2004), caso ocorresse deformação ou degeneração, haveria diminuição do diâmetro interno, além do aumento da dureza do material, o que poderia causar aumento da força de retenção, ao contrário do que ocorreu neste estudo.

O presente estudo apresenta diversas limitações inerentes às pesquisas in vitro, pois a condição da cavidade oral pode influenciar os resultados. Clinicamente, o paciente poderá remover e inserir quantas vezes forem necessárias suas próteses, ao contrário do estudo que padronizou quatro inserções e remoções diárias. Além disso, a força utilizada pelo paciente pode variar consideravelmente, assim como a modificação do eixo de inserção, o que foi padronizado neste trabalho. Para reduzir os vieses do trabalho, foram utilizados anéis do mesmo lote e as condições de imersão foram mantidas padronizadas também.

Este estudo avaliou o efeito isolado das soluções em quatro períodos (inicial, 30, 60 e 90 dias após as imersões), entretanto múltiplos ciclos de inserção e remoção entre os períodos de imersão poderiam demonstrar resultados diferentes. Ensaios de fadiga não foram realizados, visando justamente isolar o efeito das soluções e eliminar outros fatores que poderiam influenciar no resultado da retenção do material avaliado. Somente foram utilizados o'rings de uma marca comercial, sem a intenção de comparar diferentes marcas comerciais. Ainda, os espécimes ficaram imersos continuamente nas soluções, com as trocas a cada 8 horas, pelo equivalente a 3 meses, sem nenhum período fora da solução que não fosse o tempo 
de realização dos ensaios de tração. Quando avaliado clinicamente, o paciente realiza intervalos entre as imersões, deixando ou não sua prótese em uso na cavidade oral. Outro fator a ser considerado é o tempo total do experimento, tendo sido verificado que já em 3 meses de simulação foram encontrados resultados de perda de retenção, apesar do pico de retenção estar acima do mínimo necessário. Estudos de 6 meses ou maior tempo poderiam ser mais conclusivos.

Este é o primeiro estudo que avalia o efeito das soluções higienizadoras diárias, neste tipo de encaixe, o o'ring de nitrilo. Desta forma, são poucos os estudos que podem ser considerados como base de comparação. Não são raros os estudos que avaliam o desgaste dos anéis por meio de ensaios de fadiga. Entretanto, somente foram encontrados os poucos artigos descritos neste trabalho que envolvem soluções higienizadoras, mas com ciclagem mecânica associada (NIGUYEN et al, 2010; YOU et al., 2011) e, apenas um deles avaliando especificamente a solução (VARGHESE et al., 2007, porém com outro modelo experimental (clipe).

O intuito desta pesquisa foi avaliar apenas a ação específica das soluções sobre os anéis de retenção. Pesquisas futuras devem ser conduzidas de forma a complementar os resultados obtidos nesta fase estática, incluindo ensaios dinâmicos e novos produtos de higienização de próteses removíveis, além da realização de ensaios clínicos. 
7 conclusões 
Dentre as limitações do presente estudo, pode-se concluir que:

1. Entre as soluções avaliadas, o hipoclorito de sódio $0,05 \%$ causou a maior redução da força de retenção dos o'rings.

2. Os enxaguatórios Cepacol e Listerine propiciaram resistência à tração similar à água deionizada.

3. O Cepacol Flúor propiciou resistência à tração similar aos enxaguatórios Cepacol e Listerine.

4. No Cepacol e no hipoclorito de sódio a retenção diminuiu significativamente a partir de 30 dias. No Listerine e Cepacol Flúor, a diminuição da retenção ocorreu após 60 dias de experimento. $\mathrm{Na}$ água deionizada, a retenção se manteve pelo período de 90 dias.

5. Após 90 dias, o Cepacol propiciou retenção similar à água deionizada.

6. Os valores obtidos em todas as soluções se apresentaram acima do mínimo indicado para a retenção $(5 \mathrm{~N})$, entretanto as soluções de hipoclorito de sódio 0,05\% e Cepacol Flúor devem ser evitadas devido aos efeitos deletérios causados no material. 
8 Referências 
1. ABELSON, D.C. Denture plaque and denture cleansers. J Prosthet Dent 1981;45(4):376-379.

2. ABELSON, D.C. Denture plaque and denture cleansers: Review of the literature. Gerodontics 1985;1(5):202-206.

3. ABERE, D.J. Post-placement care of complete and removable partial dentures. Dent Clin N Am 1979;23(1):143-151.

4. ALLEN, P.F., MCMILLAN, A.S.; SMITH, D.G. Complications and maintenance requirements of implant-supported prosthesis provided in a UK dental hospital. Br Dent J 1997;182(8):298-302.

5. ANDRÉ, R.F.; ANDRADE, I.M.; SILVA-LOVATO, C.H.; PARANHOS, H.F.O. PIMENTA, F.C.; ITO, I.Y. Prevalence of mutans streptococci isolated from complete dentures and their susceptibility to mouthrinses. Braz Dent $\mathrm{J}$ $2011 ; 22(1): 62-7$.

6. ANDRUP, B., ANDERSSON, B., HEDEGÅRD, B. Denture hygiene III. Does the cleaning of complete dentures help to cure stomatitis? Tandlakartidningen, Swedish 1977; 69(7):394-8.

7. AUGSBURGER, R.H.; ELAHI, J.M. Evaluation of seven proprietary denture cleansers. J Prosthet Dent 1982;47(4):356-359.

8. ASHTON, L.A., BLOCH, G.A. Cleanser effects on denture materials. Georgetown Dent J. 1971;37(2):12-4.

9. BACKENSTOSE, W.M.; WELLS, J.G. Side effects of immersion-type cleansers on the metal components of dentures. J Prosthet Dent 1977;37(6):615-621.

10. BARÃO, V.A.R.; ASSUNÇÃO, W.G.; TABATA, L.F.; DELBEN, J.A.; GOMES, E.A.; SOUZA, E.A.C.; ROCHA, E.P. Finite element analysis to compare 
complete denture and implant-retained overdenturess with different attachments systems. The J Craniofac Surg 2009;20(4):1066-1071.

11.BARBEAU, J.; SÉGUIN, J.; GOULET, J.P.; de KONINCK, L.; AVON, S.L.; LALONDE, B.; ROMPRÉ, P.; DESLAURIERS, N. Reassessing the presence of Candida albicans in denture-related stomatitis. Oral Surg Oral Med Oral Pathol Oral Radiol Endod 2003;95(1):51-59.

12. BARBEAU, J.; SÉGUIN, J.; GOULET, J.P.; DE KONINCK, L.; AVON, S.L.; LALONDE, B.; ROMPRÉ, P.; DESLAURIERS, N. Reassessing the presence of Candida albicans in denture-related stomatitis. Oral Surg Oral Med Oral Pathol Oral Radiol Endod 2003;95(1):51-9.

13. BARNABÉ, W.; MENDONÇA NETO, T.; PIMENTA, F.C.; PEGORARO, L.F.; SCOLARO, J.M. Efficacy of sodium hypochlorite and coconut soap used as disinfecting agents in the reduction of denture stomatitis, Streptococcus mutans and Candida albicans. J Oral Rehabil 2004;31:453-459.

14.BAYER, S.; STEINHEUSER, D.; GRÜNER, M.; KEILIG, L.; ENKLING, N.; STARK, H.; MUES, S. Comparative study of four retentive anchor systems for implant supported overdentures--retention force changes. Gerodontology. 2009;26(4):268-72.

15. BERGER, J.C.; DRISCOLL, C.F.; ROMBERG, E.; LUO, Q.; THOMPSON, G. Surface roughness of denture base acrylic resins after processing and after polishing. J Prosthodont 2006;15(3):180-6.

16. BILHAN, H.; GECKILI, O.; MUMCU, E.; BILMENOGLU, C. Maintenance requirements associated with mandibular implant overdentures: clinical results after first year of service. J Oral Implantology 2011;37(6):697-704. 
17. BONACHELA, W.C.; PEDREIRA, A.P.; MARINS, L.; PEREIRA, T. Comparative evaluation of retention loss in four types of attachments used on overdentures in function of time of use. J Appl Oral Sci 2003;11(1):49-54.

18. BOTEGA, D.M.; MESQUITA, M.F.; HENRIQUES, G.E.; VAZ, L.G. Retention force and fatigue strength of overdenture attachment systems. J Oral Rehabil 2004;31(9):884-9.

19.BUDTZ-JØRGENSEN, E. Materials and methods for cleaning dentures. J Prosthet Dent 1979;42(6):619-623.

20.BUERGERS, R.; ROSENTRITT, M.; SCHNEIDER-BRACHERT, W.; BEHR M.; HANDEL, G.; HAHNEL, S. Efficacy of denture didinfection methods in controlling Candida albicans colonization in vitro. Acta Odontol Scand 2008;66(3):174-80.

21.BURNS, D.R.; UNGER, J.W.; COFFEY, J.P.; WALDROP, T.C.; ELSWICK, R.K. Randomized, prospective, clinical evaluation of prosthodontic modalities for mandibular implant overdenture treatment. J Prosthet Dent 2011;106:1222.

22. CATAlAN, A.; CELIS, A.; REVECO, A. Stomatitis under prosthesis. Odontol Chil. 1977;25(118):102-6.

23. CHAN, E. C. S.; IUGOVAZ, I; SILBOO, R.; BILYK, M.; BAROLET, R.; AMSEL, R.; WOOLEY, C.; KLITORINOS, A. Comparison of two popular methods for removal and killing of bacteria from dentures. J. Can. Dent. Assoc. $1991 ; 57(12): 937-9$

24. COUNCIL ON DENTAL MATERIALS, INSTRUMENTS AND EQUIPMENT. Denture cleansers. J Am Dent Assoc 1983;106(1):77-79. 
25. COUNCIL ON DENTAL THERAPEUTICS AND COUNCIL ON PROSTHETIC SERVICES AND DENTAL LABORATORY RELATIONS. Guidelines for infection control in dental office and the commercial dental laboratory. J Am Dent Assoc. 1985; 110(6):969-72.

26.DAVI, L.R.; FELIPUCCI, D.N.B.; SOUZA, R.F.; BEZZON, O.L.; LOVATOSILVA, C.H.; PAGNANO, V.O.; PARANHOS, H.F.O. Effect of denture cleansers on metal ion release and surface roughness of denture base materials. Braz Dent J 2012;23(4):387-93.

27.DE PAOLA, L.G.; MINAH, G.E.; ELIAS, S.A. Evaluation of agents to reduce microbial growth on dental prostheses of myelosupressed cancer patients. Clin Prev Dent 1984;6(2):9-12.

28. DEVLIN, H.; BEDI, R. Denture use and abuse. Dent Update 1988;15(2):78-80.

29.DHAMANDE, M.M.; PAKHAN, A.J.; THOMBARE, R.U.; GHODPAGE, S.L. Evaluation of efficacy of commercial denture cleansing agents to reduce the fungal biofilm activity from heat polymerized denture acrylic resin: an in vitro study.Contemp Clin Dent 2012;3(2):168-72.

30.DILLS, S.S.; OLSHAN, A.M.; GOLDNER, S.; BROGDON, C. Comparison of the antimicrobial capability of an abrasive paste and chemical-soak denture cleansers. J Prosthet Dent 1988;60:467-470.

31. EMAMI, E.; TARAF, H.; de GRANDMONT, P.; GAUTHIER, G.; KONINCK, L.; LAMARCHE, C.; de SOUZA, R.F. The association of denture stomatitis and partial removable dental prostheses: a systematic review. Int J Prosthont 2012;25(2);113-9. 
32. EPSTEIN, D.D.; EPSTEIN, P.L.; COHEN, B.I.; PAGNILLO, M.K. Comparison of the retentive properties of six prefabricated post overdenture attachment systems. J Prosthet Dent. 1999;82(5):579-84.

33.FAIS, L.M.G.; FERNANDES-FILHO, R.; PEREIRA-DA-SILVA, M.A.; VAZ, L.G.; ADABO, G.L. Titanium surface topography after brushing with fluoride and fluoride -free toothpaste simulating 10 years of use. J Dent 2012;40:265275.

34. FATALLA, A.A.; SONG, K.; DU, T.;CAO, Y. An in vitro investigation into retention strength and fatigue resistance of various designs of tooth/implant supported overdentures. J Huazong Univ Sci Technol 2012;32(1):124-9.

35. FELIPUCCI, D.N.B.; DAVI, L.R.; PARANHOS, H.F.O.; BEZZON, O.L.; SILVA, R.F.; PAGNANO, V.O. Effect of different cleansers on the surface of removable partial denture. Braz Dent J. 2011a;22(5):392-7.

36. FELIPUCCI, D.N.B.; DAVI, L.R.; PARANHOS, H.F.O.; BEZZON, O.L.; SILVA, R.F.; BARBOSA-JUNIOR, F.; PAGNANO, V.O. Effect of different cleansers on the weight and ion release of removable partial denture: an in vitro study. $\mathrm{J}$ Appl Oral Sci. 2011b;19(5):483-7.

37. FELTON, D.; COOPER, L.; MINSLEY, G.; GUCKES, A.; HAUG, S.; MEREDITH, P.; SOLIE, C.; AVERY, D.; CHANDLER, N.D. Evidence-based guidelines for the care and maintenance of complete dentures: a publication of the American College of Prosthodontics. JADA 2011;142(1):1S-20S.

38. FERRAN, P.; MIGUEL, J.L.; BOUSQUET, A.; DUBOIS, J. Hygiène et prophylaxie em prótese dentaire complete chez la personne âgée. Inf Dent. 1984;66(15):1509-15. 
39. FERREIRA, M.A.; PEREIRA-CENCI, T.; RODRIGUES-VASCONCELOS, L.M.; RODRIGUES-GARCIA, R.C. DEL BEL CURY, A.A. Efficacy of denture cleansers on denture liners contaminated with Candida species. Clin Oral Insvestig 2009;13(2):237-42.

40. FOUCHE, M.H.; SLABBERT, J.C.; COOGAN, M.M. Microorganisms isolated from patients with denture stomatitis. J Dent Assoc S Afr. 2009;41(6):313-6.

41.GARCIA, R.C.M.R.; SOUZA Jr, J.A.; RACHED, R.N.; DEL BEL CURY, A.A. Effect of denture cleansers on the surface roughness and hardness of a microwave-cured acrylic resin and dental alloys. J Prosthodont 2004;13(3):194-9.

42. HOAD-REDDICK, G.; GRANT, A.A.; GRIFFITHS, C.S. Investigation into the cleanliness of dentures in an eldery population. J Prosthet Dent. 1990;64(1): 48-52.

43. HONG, G.; MURATA, H.; LI, Y.; SADAMORI, S.; HAMADA, T. Influence of denture cleansers on the color stability of three types of denture base acrylic resin. J Prosthet Dent. 2009;101(3):205-13.

44. ITO, I. Y.; VERRI, R. A.; RIBAS, J. P.; DE LIMA, S. N. M.; PALAMIN, R. V.; CAMPOS, G. M. Efeitos do Cloreto de Cetilpiridíneo na inibição da placa dental. Odont. Moderno 1980;7(2):8-23.

45.JAGGER, D.C.; AL-AKHAZAMI, L.; HARRISON, A.; REES, J.S. The effectiveness of seven denture cleansers on tea stain removal from PMMA acrylic resin. Int J Prosthodont 2002;15:549-552.

46. JAGGER, D.C.; HARRISON, A. Denture cleansing - The best approach. Br Dent J 1995;178(11):413-417. 
47. KARABUDA, C.; YALTIRIK, M.; BAYRAKTAR, M. A clinical comparison of prosthetic complications of implant-supported overdentures with different attachment systems. Implant Dent. 2008;17(1):74-81.

48. KEMPLER, D.; MYER, M.; KAHL, E.A.; MARTIN, D.W. The efficacy of sodium hypoclorite as a denture cleanser. Spec Care Dentist 1982;2(3):112-5.

49. KEYF, F.; GÜNGÖR, T. Comparison of effects of bleach and tablet on reflectance and surface changes of a dental alloy used for removable partial dentures. J Biomater Appl 2003;18(1):5-14.

50. KULAK, Y.; ARIKAN, A.; ALBAK, S.; OKAR, I.; KAZAZOGLU, E. Scanning electron microscopic examination of different cleaners: surface contaminant removal from dentures. J Oral Rehabil. 1997;24(3): 209-15.

51.KULAK-OZKAN, Y.; KAZAZOGLU, E.; ARIKAN A. Oral hygiene habits, denture cleanliness, presence of yeasts and stomatitis in elderly people. $J$ Oral Rehabilitation 2002;29:300-304.

52. LACERDA, T.S.P. Quais são os recursos utilizados para a limpeza das próteses totais? Rev Assoc Paul Cir Dent 1998;52(3):217-218.

53. LAMFON, H., AL-KARAAWI, Z.; McCULlOUGH, M., PORTER, S.R., PRATTEN, J. Composition of in vitro denture plaque biofilms and susceptibility to antifungicals. FEMS Microbiol Lett. 2005;242(2):345-51.

54.LEE, H.E.; WANG, C.C.; WANG, J.C.; CHEN, C.P. the effect of denture cleansers and cleansing methods on the microflora of denture plaque. Gaoxiong Yi Xue Ke Xue Za Zhi. 1985;1(2):88-94.

55. LEHMANN, K.M.; ARNIM, F.V. Studies on the retention forces of snap-on attachments. Quint Dent Technol 1978;7:45-8. 
56.LESSA, F.C.; ENOKI, C.; ITO, I.Y.; FARIA, G.; MATSUMOTO, M.A.; NELSON-FILHO, P. In-vivo evaluation of the bacterial contamination and disinfection of acrylic baseplates of removable orthodontic appliances. Am J Orthod Dentofacial Orthop 2007;131(6):11-7.

57. LOVATO -SILVA, C.H..; PARANHOS, H.F.O.; ITO, I.Y. Evidenciadores de biofilme em prótese total: avaliação clínica e antimicrobiana. Pesqui Odontol Bras 2002;16(3):270-275.

58. MACCALLUM, M.; STAFFORD, G.D.; MACCULLOCH, W.T.; COMBE, E.C. Wich cleanser? A report on a survey of denture cleansing routine and the development of a new denture cleanser. Dent Pract Dent Rec 1968;19(3):839.

59. MACHADO, A.C.M.; CARDOSO, L.; BRANDT, W.C.; HENRIQUES, G.E.P.; NÓBILO, M.A.A. Photoelastic analysis of the distribution of stress in different systems of overdentures on osseous-integrated implants. J Cranioc Surg $2011 ; 22(6): 2332-6$.

60. MÄHÖNEN, K.; VIRTANEN, K.; LARMAS, M. The effect of prosthesis disinfection on salivary microbial levels. J Oral Rehabil 1998;25(4):304-310.

61. MONTAGNER, H.; MONTAGNER, F.; BRAUN, K.O.; PERES, P.E.; GOMES, B.P. In vitro antifungal action of different substances over microwaved-cured acrylic resins. J Appl Oral Sci 2009;17(5):432-5.

62. NAERT, I.; ALSAAD, G.; QUIRYNEN, M. Prosthetic aspects and patient satisfaction with two-implant-retained mandibular overdentures: a 10-year randomized clinical study. Int J Prosthodont 2004;17:401-10.

63. NALBANT, A.D.; KALKANCI, A.; FILIZ, B.; KUSTIMUR, S. Effectiveness of different cleaning agents against the colonization of Candida spp and the in 
vitro detection of the adherence of these yeast cells to denture acrylic surfaces. Yonsei Med J 2008;49(4):647-54.

64. NEILL, D.J. A study of materials and methods employed in cleaning dentures. Br Dent J 1968;124(3):107-115.

65. NGUYEN, C.T.; MASRI, R.; DRISCOLL, C.F.; ROMBERG, E. The effect of denture cleansing solutions on the retention of pink Locator attachments: an in vitro study. J Prosthodont. 2010;19(3):226-30.

66. NIKAWA, H.; HAMADA, T.; YAMAMOTO, T. Denture plaque - past and recent concerns. J Dent 1998;26(4):299-304.

67. NIKAWA, H.; HAMADA, T.; YAMASHIRO, H.; KUMAGAI, H. A review of in vitro and in vivo methods to evaluate the efficacy of denture cleansers. Int $\mathrm{J}$ Prosthod 1999;12(2):153-159.

68. NIKAWA, H.; JIN, C.; MAKIHIRA, S.; EGUSA, H.; HAMADA, T.; YAMASHIRO, H.; KUMAGAI, H. Biofilm formation of Candida albicans on the surfaces of deteriored soft denture lining materials caused by denture cleansers in vitro. $\mathrm{J}$ Oral Reahabil 2003;30(3):243-50.

69. PARANHOS, H.F.O.; MALACHIAS, A.; PARDINI, L.C. Materiais para limpeza de dentaduras: revisão da literatura. Rev Fac Odontol Lins 1991;4(2):19-24.

70. PARANHOS, H.F.O.; PANZERI, H.; LARA, E.H.G.; CANDIDO, R.C.; ITO, I.Y. Capacity of denture plaque/biofilm removal and antimicrobial action of a new denture paste. Braz Dent J 2000;11(2):97-104.

71.PARANHOS, H.F.O.; SILVA-LOVATO, C.H.; SOUZA, R.F.; CRUZ, P.C.; FREITAS, K.M.; PERACINI, A. Effects of mechanical and chemical methods on denture biofilm accumulation. J Oral Rehabil 2007;34:606-612. 
72.PARANHOS, H.F.O.; SILVA-LOVATO, C.H.; SOUZA, R.F.; CRUZ, P.C.; FREITAS-PONTES, K.M.; WATANABE, E.; ITO, I.Y. Effect of three methods for cleaning dentures on biofilms formed in vitro on acrylic resin. J Prosthod 2009; 18:427-431.

73. PERACINI, A.; ANDRADE, I.M.; PARANHOS, H.F.O.; SILVA, C.H.; DE SOUZA, R.F. Behaviors and hygiene habits of complete denture wearers. Braz Dent J. 2010;21(3):247-52.

74. PETROPOULOS, V.C,; MANTE, F.K. Comparison of retention and strain energies of stud attachments for implants overdentures. J Prosthodontics 2011;20:286-293.

75.PINTO, T.M.; NEVES, A.C.; LEÃO, M.V.; JORGE, A.O. Vinegar as an antimicrobial agent for control of Candida spp. in complete denture wearers. J Appl Oral Sci, 2008;16(6):385-90.

76. RAMAGE, G.; ZALEWSKA, A.; CAMERON, D.A.; SHERRY, L.; MURRAY, C.; FINNEGAN, M.B.; LOEWY, Z.G. A comparative in vitro study of two denture cleaning techniques as an effective strategy for inhibiting Candida albicans biofilms on denture surfaces and reducing inflammation. J Prosthod 2012;21:516-22.

77.RIBEIRO, D.G.; PAVARINA, A.C.; GIAMPAOLO, E.T.; MACHADO, A.L.; JORGE, J.H.; GARCIA, P.P. Effect of oral hygiene education and motivation on removable partial denture wearers: longitudinal study. Gerodontology 2009;26(2):150-6.

78. RIGDON, T.F. The removable implant overdenture - "why didn't someone tell me that?" J Oral Implantol 1996;22(1):59-62. 
79.RODRIGUES, R.C.; FARIA, A.C.; MACEDO, A.P.; SARTORI, I.A.; DE MATTOS MDA G.; RIBEIRO, R.F. An in vitro study of non-axial forces upon the retention of an O-ring attachment. Clin Oral Implants Res 2009;20(12):1314-9.

80.RUTKUNAS, V.; MIZUTANI, H.; TAKAHASHI, H.; IWASAKI, N. Wear simulation effects on overdenture stud attachments. Dent Mat $\mathrm{J}$ 2011;30(6):845-853.

81. SAAVEDRA, G.; BARBOSA, S.H.; LANDIN, K.T.; ALONSO, AL.A.; VASCONCELOS, D.K.; AVELAR, R.P.; BOTTINO, M.A.; KIMPARA, E.T. Influência do ângulo de inserção na degradação daretenção do o-ring em overdenture. ImplantNews 2007;4(3):249-53.

82.SATO, S.; CAVALCANTE, M.R.S.; ORSI, I.A.; PARANHOS, H.F.O.; ZANIQUELLI, O. Assessment of flexural strenght and color alteration of heatpolymerized acrylic resins after simulated use of denture cleansers. Braz Dent J 2005;16(2):124-8.

83. SECRETARIA DE ATENÇÃO À SAÚDE. Portaria 718/SAS DE 20/12/2010. Diário Oficial da União 2010;251:100-13.

84. SESMA, N.; TAKADA, K.S.; LAGANÁ, D.C.; JAEGER, R.G.; AZAMBUJA Jr, N. Eficiência de métodos caseiros de higienização de próteses parciais removíveis. Rev Assoc Paul Cir Dent 1999;53(6):463-467.

85. SEXSON, J.C.; PHILLIPS, R.W. Studies on the effects of abrasives on acrylic resins. J Prosthet Dent. 1951; 1(4):54-71.

86. SHAY, K. Denture Hygiene: A Review and Update. J Contemp Dent Pract 2000;1(2):1-8. 
87. SHEEN, S.R.; HARRISON, A. Assessment of plaque prevention on dentures using an experimental cleanser. J Prosthet Dent 2000;84:594-601.

88. SHIP, J.A.; PILLEMER, S.R.; BAUM, B.J. Xerostomia and the geriatric patient. J Am Geriatr Soc 2002;50(3):535-543.

89. SMITH, D.C. Denture Cleansers. Dent Pract Dent Rec 1961; 12(3):93-4.

90.SMITH, D.C. The cleansing of denture. Dent Pract Dent Rec 1966;17(2):3943.

91. de SOUZA, R.F.; PARANHOS, H.F.O.; LOVATO-SILVA, C.H.; ABU-NABA'A, L.; FEDOROWICZ, Z.; GURGAN, C.A. Interventions for cleaning dentures in adults. Cochrane Database Syst Rev 2009;7(4):CD007395.

92. SUZUKI, Y.; OHKUBO, C.; KURTZ, K.S. Clinical application of stress-breaking ball attachment for implant overdenture. J Prosthod Res 2013;57:140-4.

93. TABATABAIAN, F.; ALAIE, F.; SEYEdAN, K. Comparison of three attachments in implant-tissue supported overdentures: an in vitro study. J Dent 2010;7(3):113-8.

94.TARBET, W.J.; AXELROD, S.; MINKOFF, S; FRATARCANGELO, P.A. Denture cleansing: a comparison of two methods. J Prosthet Dent 1984;51(3):322-5.

95. THEILADE, E.; BUDTZ-JØRGENSEN, E. Predominant cultivable microflora of plaque on removable dentures in patients with denture-induced stomatitis. Oral Microbiol Immunol 1988;3(1):8-13.

96. TONIOLLO, M.B.; GALO, R.; MACEDO, A.P.; RODRIGUES, R.C.; RIBEIRO, R.F.; MATTOS, M.G. Effect of fluoride sodium mouthwash solutions on Ti cp: evaluation of physicochemical properties. Braz Dent J 2012;23(5);496-501. 
97.TORRES, S.R.; PEIXOTO, C.B.; CALDAS, D.M.; SILVA, E.B.; AKITI, T.; NUCCI, M.; UZEDA, M. Relationship between salivary flow rates and Candida counts in subjects with xerostomia. Oral Surg Oral Med Oral Pathol Oral Radiol Endod 2002;93(2):149-154.

98. ULUDAMAR, A.; OSKAN, Y.; KADIR, T.; CEYHAN, I. In vivo efficacy of alkaline peroxide tablets and mouthwashes on Candida albicans in patients with denture stomatitis. J App Oral Sci 2010;18(3):291-6.

99. ÜNLÜ, A.; ALTAY, O.T.; SAHMALI, S. The role of denture cleansers on the whitening of acrylic resins. Int J Prosthodont 1996;9:266-270.

100. van der BILT, A.; BURGERS, M.; van KAMPEN, F.M.C.; CUNE, M.S. Mandibular implant-supported overdentures an oral function. Clin Oral Impl Res 2010;21:1209-1213.

101. van KAMPEN, F.; CUNE, M.; van der BILT, A.; BOSMAN, F. Retention and postinsertion maintenance of bar-clip, ball and magnet attachments in mandibular implant overdenture treatment: an in vivo comparison after 3 months of function. Clin Oral Implants Res 2003;14(6):720-6.

102. VAN REENEN, J.F. Microbiologic studies on denture stomatitis. J Prosthet Dent 1973;30(4):493-505.

103. VANDENBUSSCHE, M.; SWINNE, D. Yeasts oral carriage in denture wearers. Mykosen Suppl 2010;27(9):431-5.

104. VARGHESE, R.M.; MASRI, R.; DRISCOLL, C.F.; ROMBERG, E. The effect of denture cleansing solutions on the retention of yellow Hader clips: an in vitro study. J Prosthodont 2007;16(3):165-71. 
105. VIEIRA, A.P.; SENNA, P.M.; SILVA, W.J.; DEL BEL CURY, A.A. Long-term efficacy of denture cleansers in preventing Candida ssp. biofilm reclonization on liner surface. Braz Oral Res 2010;24(3):342-8.

106. WAGNER, A.G. Maintenance of the partially edentulous mouth and care of the denture. Dent Clin North Am 1973;17:755.

107. WALBER, L.F.; RADOS, P.V. Estudo comparativo de tratamento da estomatite protética pelo reembasamento ou substituição das próteses totais. Rev Fac Odontol Porto Alegre 2000;40(2):17-23.

108. WALKER, C.B. Microbiological effects of mouthrinses containing antimicrobials. J Clin Periodonto 1988;15(8):499-505.

109. WALTON, J.N. A randomized clinical trial comparing two mandibular implant overdenture designs: 3-year prosthetic outcomes using a six-field protocol. Int J Prosthodont 2003;16(3):255-60.

110. WATANABE, E.; TANOMARU, J.M.; NASCIMENTO, A.P.; MATOBAJÚNIOR, F.; TANOMARU-FILHO, M.; YOKO ITO, I. Determination of the maximum inhibitory dilution of cetylpyridinium chloride-based mouthwashes against Staphylococcus aureus: an in vitro study. J Appl Oral Sci 2008;16(4):275-9.

111. WEBB, B.C.; WILLCOX, M.D.; THOMAS, C.J.; HARTY, D.W.; KNOX, K.W. The effect of sodium hypochlorite on potential pathogenic traits of Candida albicans and other Candida species. Oral Microbiol Immunol 1995;10(6):33441.

112. WICHMANN, M.G.; KUNTZE, W. Wear behavior of precision attachments. Int J Prosthodont 1999;12(5):409-14. 
113. YANG, T.; MAEDA, Y.; GONDA, T.;KOTECHA, S. Attachments systems for implant overdentures: influence of implant inclination on retentive and lateral forces. Clin Oral Impl Res 2011;22:1315-1319.

114. YOU, W.; MASRI, R.; ROMBERG, E.; DRISCOLL, C.F., YOU, T. The effect of denture cleansing solutions on the retention of pink locator attachments after multiple pulls: an in vitro study. J Prostodont 2011;20:464-9. 
Apêndice 
Apêndice A. Resultados do ensaio de resistência à tração dos anéis de borracha $(\mathrm{N})$.

\begin{tabular}{|c|c|c|c|c|}
\hline \multirow[b]{2}{*}{ Soluções } & \multicolumn{4}{|c|}{ Tempos } \\
\hline & T0 & T1 & T2 & T3 \\
\hline \multirow{6}{*}{ Água deionizada } & 9,37 & 9,71 & 8,96 & 8,83 \\
\hline & 10,71 & 9,15 & 9,2 & 9,42 \\
\hline & 12,85 & 11,67 & 11,76 & 10,89 \\
\hline & 11,26 & 10,78 & 10,58 & 9,79 \\
\hline & 11,18 & 12,08 & 11,2 & 12,72 \\
\hline & 13,57 & 12,07 & 12,24 & 11,8 \\
\hline \multirow{6}{*}{ Cepacol } & 10,93 & 9,15 & 9,45 & 8,9 \\
\hline & 11,82 & 10,67 & 9,73 & 9,51 \\
\hline & 10,04 & 9,87 & 9,34 & 9,67 \\
\hline & 12,81 & 11,06 & 10,89 & 10,09 \\
\hline & 11,9 & 10,67 & 10,56 & 9,48 \\
\hline & 12,71 & 10,5 & 10,89 & 9,27 \\
\hline \multirow{6}{*}{$\begin{array}{l}\text { Cepacol } \\
\text { Flúor }\end{array}$} & 9,21 & 8,63 & $\overline{7,3}$ & 7,78 \\
\hline & 10,65 & 9,15 & 8,73 & 7,67 \\
\hline & 12,89 & 10,89 & 9,68 & 8,45 \\
\hline & 11,51 & 9,78 & 8,36 & 7,9 \\
\hline & 10,78 & 9,23 & 9,38 & 8,56 \\
\hline & 8,42 & 9,1 & 7,7 & 7,56 \\
\hline \multirow{6}{*}{$\begin{array}{l}\text { Hipoclorito de } \\
\text { Sódio 0,05\% }\end{array}$} & 11,2 & 6,7 & 5,87 & 5,34 \\
\hline & 9,68 & 6,47 & 4,89 & 6,49 \\
\hline & 9,87 & 7,8 & 5,78 & 5,46 \\
\hline & 10,57 & 6,75 & 5,34 & 5,3 \\
\hline & 13,19 & 6,28 & 5,5 & 5,02 \\
\hline & 8,57 & 6,29 & 4,99 & 4,74 \\
\hline \multirow{6}{*}{ Listerine } & 11,88 & 10,56 & 9,38 & 8,74 \\
\hline & 11,72 & 11,02 & 9,45 & 8,83 \\
\hline & 11,29 & 10,46 & 9,1 & 8,83 \\
\hline & 11,72 & 9,97 & 7,89 & 8,11 \\
\hline & 13,01 & 11,03 & 8,3 & 7,36 \\
\hline & 12,21 & 11,45 & 10,45 & 9,42 \\
\hline Média & 11,25 & 9,63 & 8,76 & 8,40 \\
\hline Desvio Padrão & 1,37 & 1,74 & 2,06 & 1,93 \\
\hline
\end{tabular}


Apêndice B. Resultados da análise estatística descritiva realizada no SPSS 17.0.

\section{Descriptives}

\begin{tabular}{|c|c|c|c|c|}
\hline & & & Statistic & Std. Error \\
\hline \multirow[t]{13}{*}{ T0 } & Mean & & 11,2507 & ,25098 \\
\hline & $95 \%$ Confidence & Lower Bound & 10,7374 & \\
\hline & Interval for Mean & Upper Bound & 11,7640 & \\
\hline & 5\% Trimmed Mean & & 11,2833 & \\
\hline & Median & & 11,2750 & \\
\hline & Variance & & 1,890 & \\
\hline & Std. Deviation & & 1,37466 & \\
\hline & Minimum & & 8,42 & \\
\hline & Maximum & & 13,57 & \\
\hline & Range & & 5,15 & \\
\hline & Interquartile Range & & 1,90 & \\
\hline & Skewness & &,- 338 & 427 \\
\hline & Kurtosis & &,- 530 & ,833 \\
\hline \multirow[t]{13}{*}{ T1 } & Mean & & 9,6313 & ,31746 \\
\hline & $95 \%$ Confidence & Lower Bound & 8,9821 & \\
\hline & Interval for Mean & Upper Bound & 10,2806 & \\
\hline & $5 \%$ Trimmed Mean & & 9,6815 & \\
\hline & Median & & 9,9200 & \\
\hline & Variance & & 3,023 & \\
\hline & Std. Deviation & & 1,73878 & \\
\hline & Minimum & & 6,28 & \\
\hline & Maximum & & 12,08 & \\
\hline & Range & & 5,80 & \\
\hline & Interquartile Range & & 1,94 & \\
\hline & Skewness & &,- 727 & 427 \\
\hline & Kurtosis & &,- 434 & 833 \\
\hline
\end{tabular}




\begin{tabular}{|c|c|c|c|c|}
\hline \multirow[t]{13}{*}{ T2 } & Mean & & 8,7630 & , 37581 \\
\hline & $95 \%$ Confidence & Lower Bound & 7,9944 & \\
\hline & Interval for Mean & Upper Bound & 9,5316 & \\
\hline & $5 \%$ Trimmed Mean & & 8,7920 & \\
\hline & Median & & 9,2700 & \\
\hline & Variance & & 4,237 & \\
\hline & Std. Deviation & & 2,05838 & \\
\hline & Minimum & & 4,89 & \\
\hline & Maximum & & 12,24 & \\
\hline & Range & & 7,35 & \\
\hline & Interquartile Range & & 2,88 & \\
\hline & Skewness & &,- 509 & ,427 \\
\hline & Kurtosis & &,- 575 & ,833 \\
\hline \multirow[t]{13}{*}{ T3 } & Mean & & 8,3977 & ,35255 \\
\hline & $95 \%$ Confidence & Lower Bound & 7,6766 & \\
\hline & Interval for Mean & Upper Bound & 9,1187 & \\
\hline & $5 \%$ Trimmed Mean & & 8,3726 & \\
\hline & Median & & 8,7850 & \\
\hline & Variance & & 3,729 & \\
\hline & Std. Deviation & & 1,93098 & \\
\hline & Minimum & & 4,74 & \\
\hline & Maximum & & 12,72 & \\
\hline & Range & & 7,98 & \\
\hline & Interquartile Range & & 1,98 & \\
\hline & Skewness & &,- 151 & ,427 \\
\hline & Kurtosis & & ,082 & ,833 \\
\hline
\end{tabular}


Apêndice C. Resultados da análise estatística descritiva realizada no SPSS 17.0 para o fator de variação: tempo.

Descriptive Statistics

\begin{tabular}{|cc|c|c|c|}
\hline & Solução & Mean & Std. Deviation & $\mathrm{N}$ \\
\hline T0 & Água & 11,4900 & 1,51181 & 6 \\
& Cepacol & 11,7017 & 1,06349 & 6 \\
& Cepacol F & 10,5767 & 1,59927 & 6 \\
& Hipoclorito & 10,5133 & 1,58266 & 6 \\
& Listerine & 11,9717 &, 58901 & 6 \\
& Total & 11,2507 & 1,37466 & 30 \\
\hline & Água & 10,9100 & 1,25273 & 6 \\
& Cepacol & 10,3200 &, 69230 & 6 \\
& Cepacol F & 9,4633 &, 78927 & 6 \\
& Hipoclorito & 6,7150 &, 56719 & 6 \\
& Listerine & 10,7483 &, 52343 & 6 \\
& Total & 9,6313 & 1,73878 & 30 \\
\hline & Água & 10,6567 & 1,34357 & 6 \\
& Cepacol & 10,1433 &, 71910 & 6 \\
& CepacolF & 8,5250 &, 92904 & 6 \\
& Hipoclorito & 5,3950 &, 40173 & 6 \\
& Listerine & 9,0950 &, 90855 & 6 \\
& Total & 8,7630 & 2,05838 & 30 \\
\hline & Água & 10,5750 & 1,49641 & 6 \\
& Cepacol & 9,4867 &, 39732 & 6 \\
\hline T3 & Cepacol F & 7,9867 &, 41855 & 6 \\
& Hipoclorito & 5,3917 &, 59748 & 6 \\
& Listerine & 8,5483 &, 71547 & 6 \\
& Total & 8,3977 & 1,93098 & 30 \\
\hline & & & & \\
& & & & \\
& & & & \\
& & & &
\end{tabular}


Apêndice D. Resultados do teste de Bonferroni para o fator de variação: solução.

\section{Pairwise Comparisons}

Measure:MEASURE_1

\begin{tabular}{|c|c|c|c|c|c|c|}
\hline \multirow[b]{2}{*}{ (I) Solução } & \multirow[b]{2}{*}{ (J) Solução } & \multirow{2}{*}{$\begin{array}{c}\text { Mean } \\
\text { Difference (I- } \\
\mathrm{J})\end{array}$} & \multirow[b]{2}{*}{$\begin{array}{l}\text { Std. } \\
\text { Error }\end{array}$} & \multirow[b]{2}{*}{ Sig. ${ }^{a}$} & \multicolumn{2}{|c|}{\begin{tabular}{|c}
$95 \%$ Confidence Interval \\
for Difference
\end{tabular}} \\
\hline & & & & & Lower Bound & $\begin{array}{l}\text { Upper } \\
\text { Bound }\end{array}$ \\
\hline \multirow{4}{*}{$\begin{array}{l}\text { Água } \\
\text { deionizada }\end{array}$} & Cepacol & ,495 & ,468 & 1,000 &,- 946 & 1,936 \\
\hline & CepacolF & $1,770^{*}$ & ,468 & ,009 & ,329 & 3,211 \\
\hline & Hipoclorito & $3,904^{*}$ & ,468 &, 000 & 2,463 & 5,345 \\
\hline & Listerine & ,817 & 468 & ,932 &,- 624 & 2,258 \\
\hline \multirow[t]{4}{*}{ Cepacol } & Água & - & ,468 & 1,000 & $-1,936$ & 946 \\
\hline & Cepacol F & 1,275 & ,468 & ,116 &,- 166 & 2,716 \\
\hline & Hipoclorito & $3,409^{*}$ & ,468 &, 000 & 1,968 & 4,850 \\
\hline & Listerine & 322 & ,468 & 1,000 & $-1,119$ & 1,763 \\
\hline \multirow[t]{4}{*}{ Cepacol F } & Água & $-1,770^{*}$ & ,468 & 009 & $-3,211$ &,- 329 \\
\hline & Cepacol & $-1,275$ & ,468 & ,116 & $-2,716$ & , 166 \\
\hline & Hipoclorito & $2,134^{*}$ & ,468 & ,001 & 693 & 3,575 \\
\hline & Listerine &,- 953 & ,468 &, 525 & $-2,394$ & 488 \\
\hline \multirow[t]{4}{*}{ Hipoclorito } & Água & $-3,904^{*}$ & ,468 & ,000 & $-5,345$ & $-2,463$ \\
\hline & Cepacol & $-3,409^{*}$ & ,468 & ,000 & $-4,850$ & $-1,968$ \\
\hline & CepacolF & $-2,134^{\star}$ & ,468 & ,001 & $-3,575$ &,- 693 \\
\hline & Listerine & $-3,087^{*}$ & ,468 &, 000 & $-4,528$ & $-1,646$ \\
\hline \multirow[t]{4}{*}{ Listerine } & Água & - & ,468 & ,932 & $-2,258$ & 624 \\
\hline & Cepacol &,- 322 & ,468 & 1,000 & $-1,763$ & 1,119 \\
\hline & Cepacol F & 953 & ,468 & ,525 &,- 488 & 2,394 \\
\hline & Hipoclorito & $3,087^{*}$ & ,468 &, 000 & 1,646 & 4,528 \\
\hline
\end{tabular}

Based on estimated marginal means

a. Adjustment for multiple comparisons: Bonferroni.

*. The mean difference is significant at the, 05 level. 
Apêndice E. Resultados do teste de Bonferroni para a interação tempo X solução.

\section{Pairwise Comparisons}

Measure:MEASURE_1

\begin{tabular}{|c|c|c|c|c|c|c|c|}
\hline \multirow{2}{*}{$\begin{array}{l}\text { Temp } \\
0^{T}\end{array}$} & \multirow{2}{*}{$\begin{array}{l}\text { (I) } \\
\text { Solução }\end{array}$} & \multirow{2}{*}{$\begin{array}{l}\text { (J) } \\
\text { Solução }\end{array}$} & \multirow{2}{*}{$\begin{array}{c}\text { Mean } \\
\text { Difference (I- } \\
\mathrm{J})\end{array}$} & \multirow[b]{2}{*}{ Std. Error } & \multirow[b]{2}{*}{ Sig. ${ }^{a}$} & \multicolumn{2}{|c|}{$\begin{array}{l}\text { 95\% Confidence Interval for } \\
\text { Difference }^{\mathrm{a}}\end{array}$} \\
\hline & & & & & & Lower Bound & Upper Bound \\
\hline \multirow[t]{20}{*}{0} & \multirow[t]{4}{*}{ Água } & Cepacol & $\mid-, 212$ & ,767 & 1,000 & $-2,573$ & 2,150 \\
\hline & & CepacolF & ,913 & ,767 & 1,000 & $-1,448$ & 3,275 \\
\hline & & Hipoclorito & ,977 & ,767 & 1,000 & $-1,385$ & 3,338 \\
\hline & & Listerine &,- 482 & ,767 & 1,000 & $-2,843$ & 1,880 \\
\hline & \multirow[t]{4}{*}{ Cepacol } & Água & ,212 & 767 & 1,000 & $-2,150$ & 2,573 \\
\hline & & Cepacol F & 1,125 & 767 & 1,000 & $-1,236$ & 3,486 \\
\hline & & Hipoclorito & 1,188 & ,767 & 1,000 & $-1,173$ & 3,550 \\
\hline & & Listerine &,- 270 & ,767 & 1,000 & $-2,631$ & 2,091 \\
\hline & \multirow[t]{4}{*}{ Cepacol F } & Água &,- 913 & ,767 & 1,000 & $-3,275$ & 1,448 \\
\hline & & Cepacol & $-1,125$ & ,767 & 1,000 & $-3,486$ & 1,236 \\
\hline & & Hipoclorito & ,063 & ,767 & 1,000 & $-2,298$ & 2,425 \\
\hline & & Listerine & $-1,395$ & 767 & ,810 & $-3,756$ & 966 \\
\hline & \multirow[t]{4}{*}{ Hipoclorito } & Água &,- 977 & ,767 & 1,000 & $-3,338$ & 1,385 \\
\hline & & Cepacol & $-1,188$ & ,767 & 1,000 & $-3,550$ & 1,173 \\
\hline & & Cepacol F &,- 063 & 767 & 1,000 & $-2,425$ & 2,298 \\
\hline & & Listerine & $-1,458$ & 767 & 689 & $-3,820$ & ,903 \\
\hline & \multirow[t]{4}{*}{ Listerine } & Água & 482 & ,767 & 1,000 & $-1,880$ & 2,843 \\
\hline & & Cepacol & , 270 & ,767 & 1,000 & $-2,091$ & 2,631 \\
\hline & & CepacolF & 1,395 & ,767 & ,810 &,- 966 & 3,756 \\
\hline & & Hipoclor & 1,458 & 767 & 689 &,- 903 & 3,820 \\
\hline \multirow[t]{12}{*}{1} & \multirow[t]{4}{*}{ Água } & Cepacol & , 590 & ,467 & 1,000 &,- 847 & 2,027 \\
\hline & & Cepacol F & $1,447^{*}$ & 467 & ,047 & , 010 & 2,883 \\
\hline & & Hipoclorito & $4,195^{*}$ & , 467 & ,000 & 2,758 & 5,632 \\
\hline & & Listerine & 162 & 467 & 1,000 & $-1,275$ & 1,598 \\
\hline & \multirow[t]{4}{*}{ Cepacol } & Água &,- 590 & 467 & 1,000 & $-2,027$ & 847 \\
\hline & & Cepacol F & ,857 & 467 & ,783 &,- 580 & 2,293 \\
\hline & & Hipoclorito & $3,605^{*}$ & 467 & , 000 & 2,168 & 5,042 \\
\hline & & Listerine &,- 428 & ,467 & 1,000 & $-1,865$ & 1,008 \\
\hline & \multirow[t]{4}{*}{ Cepacol F } & Água & $-1,447^{*}$ & 467 & , 047 & $-2,883$ &,- 010 \\
\hline & & Cepacol &,- 857 & 467 & ,783 & $-2,293$ &, 580 \\
\hline & & Hipoclorito & $2,748^{*}$ & 467 & , 000 & 1,312 & 4,185 \\
\hline & & Listerine & $-1,285$ & 467 & 108 & $-2,722$ & 152 \\
\hline
\end{tabular}




\begin{tabular}{|c|c|c|c|c|c|c|c|}
\hline & \multicolumn{2}{|c|}{ Hipoclorito Água } & $-4,195^{*}$ & ,467 &, 000 & $-5,632$ & $-2,758$ \\
\hline & & Cepacol & $-3,605^{*}$ & ,467 &, 000 & $-5,042$ & $-2,168$ \\
\hline & & Cepacol F & $-2,748^{*}$ & ,467 &, 000 & $-4,185$ & $-1,312$ \\
\hline & & Listerine & $-4,033^{*}$ & ,467 &, 000 & $-5,470$ & $-2,597$ \\
\hline & Listerine & Água &,- 162 & ,467 & 1,000 & $-1,598$ & 1,275 \\
\hline & & Cepacol & ,428 & ,467 & 1,000 & $-1,008$ & 1,865 \\
\hline & & Cepacol F & 1,285 & ,467 & ,108 &,- 152 & 2,722 \\
\hline & & Hipoclorito & $4,033^{*}$ & ,467 &, 000 & 2,597 & 5,470 \\
\hline 2 & Água & Cepacol &, 513 &, 527 & 1,000 & $-1,110$ & 2,137 \\
\hline & & Cepacol F & $2,132^{*}$ &, 527 & ,004 &, 508 & 3,755 \\
\hline & & Hipoclorito & $5,262^{*}$ &, 527 &, 000 & 3,638 & 6,885 \\
\hline & & Listerine & 1,562 &, 527 & ,066 &,- 062 & 3,185 \\
\hline & Cepacol & Água &,- 513 & ,527 & 1,000 & $-2,137$ & 1,110 \\
\hline & & Cepacol F & 1,618 &, 527 &, 051 &,- 005 & 3,242 \\
\hline & & Hipoclorito & $4,748^{*}$ &, 527 &, 000 & 3,125 & 6,372 \\
\hline & & Listerine & 1,048 &, 527 &, 579 &,- 575 & 2,672 \\
\hline & Cepacol F & Água & $-2,132^{*}$ & ,527 & ,004 & $-3,755$ &,- 508 \\
\hline & & Cepacol & $-1,618$ & ,527 & ,051 & $-3,242$ & ,005 \\
\hline & & Hipoclorito & $3,130^{*}$ & ,527 & ,000 & 1,507 & 4,753 \\
\hline & & Listerine &,- 570 &, 527 & 1,000 & $-2,193$ & 1,053 \\
\hline & Hipoclorito & Água & $-5,262^{*}$ & ,527 & ,000 & $-6,885$ & $-3,638$ \\
\hline & & Cepacol & $-4,748^{*}$ &, 527 &, 000 & $-6,372$ & $-3,125$ \\
\hline & & Cepacol F & $-3,130^{*}$ &, 527 &, 000 & $-4,753$ & $-1,507$ \\
\hline & & Listerine & $-3,700^{*}$ & ,527 &, 000 & $-5,323$ & $-2,077$ \\
\hline & Listerine & Água & $-1,562$ &, 527 & ,066 & $-3,185$ & ,062 \\
\hline & & Cepacol & $-1,048$ & ,527 &, 579 & $-2,672$ & ,575 \\
\hline & & Cepacol F &, 570 &, 527 & 1,000 & $-1,053$ & 2,193 \\
\hline & & Hipoclorito & $3,700^{*}$ & ,527 & ,000 & 2,077 & 5,323 \\
\hline 3 & Água & Cepacol & 1,088 & ,479 & ,319 &,- 386 & 2,563 \\
\hline & & CepacolF & $2,588^{*}$ & ,479 & ,000 & 1,114 & 4,063 \\
\hline & & Hipoclor & $5,183^{*}$ & ,479 & ,000 & 3,709 & 6,658 \\
\hline & & Listerin & $2,027^{*}$ & ,479 & ,003 & ,552 & 3,501 \\
\hline & Cepacol & Água & $-1,088$ & ,479 & ,319 & $-2,563$ & ,386 \\
\hline & & Cepacol F & $1,500^{*}$ & ,479 & ,044 & ,026 & 2,974 \\
\hline & & Hipoclorito & $4,095^{*}$ & ,479 & ,000 & 2,621 & 5,569 \\
\hline & & Listerine & ,938 & ,479 & ,613 &,- 536 & 2,413 \\
\hline & Cepacol F & Água & $-2,588^{*}$ & ,479 &, 000 & $-4,063$ & $-1,114$ \\
\hline & & Cepacol & $-1,500^{*}$ & ,479 & ,044 & $-2,974$ &,- 026 \\
\hline & & Hipoclorito & $2,595^{*}$ & ,479 & ,000 & 1,121 & 4,069 \\
\hline & & Listerine &,- 562 & ,479 & 1,000 & $-2,036$ & ,913 \\
\hline
\end{tabular}




\begin{tabular}{|c|c|c|c|c|c|c|}
\hline \multicolumn{2}{|c|}{ Hipoclorito Água } & $-5,183^{*}$ & ,479 &, 000 & $-6,658$ & $-3,709$ \\
\hline & Cepacol & $-4,095^{*}$ & ,479 &, 000 & $-5,569$ & $-2,621$ \\
\hline & Cepacol F & $-2,595^{*}$ & ,479 &, 000 & $-4,069$ & $-1,121$ \\
\hline & Listerine & $-3,157^{*}$ &, 479 &, 000 & $-4,631$ & $-1,682$ \\
\hline \multirow[t]{4}{*}{ Listerine } & Água & $-2,027^{*}$ & 479 & ,003 & $-3,501$ &,- 552 \\
\hline & Cepacol &,- 938 & ,479 & ,613 & $-2,413$ &, 536 \\
\hline & Cepacol F &, 562 & ,479 & 1,000 &,- 913 & 2,036 \\
\hline & Hipoclorito & $3,157^{\star}$ & ,479 &, 000 & 1,682 & 4,631 \\
\hline
\end{tabular}

Based on estimated marginal means

a. Adjustment for multiple comparisons: Bonferroni.

*. The mean difference is significant at the ,05 level. 
Apêndice F. Resultados do teste de Bonferroni para a interação solução X tempo.

\section{Pairwise Comparisons}

Measure:MEASURE_1

\begin{tabular}{|c|c|c|c|c|c|c|c|}
\hline \multirow[b]{2}{*}{ Solução } & \multirow{2}{*}{$\begin{array}{c}(\mathrm{I}) \\
\text { tempo }\end{array}$} & \multirow{2}{*}{$\begin{array}{c}(\mathrm{J}) \\
\text { tempo }\end{array}$} & \multirow{2}{*}{$\begin{array}{c}\text { Mean } \\
\text { Difference } \\
(\mathrm{I}-\mathrm{J})\end{array}$} & \multirow[b]{2}{*}{ Std. Error } & \multirow[b]{2}{*}{ Sig. ${ }^{a}$} & \multicolumn{2}{|c|}{$\begin{array}{l}\text { 95\% Confidence Interval for } \\
\text { Difference }^{\mathrm{a}}\end{array}$} \\
\hline & & & & & & Lower Bound & Upper Bound \\
\hline \multirow[t]{12}{*}{ Água } & 0 & 1 &, 580 & ,448 & 1,000 &,- 703 & 1,863 \\
\hline & & 2 & ,833 & ,404 & ,297 &,- 324 & 1,990 \\
\hline & & 3 & ,915 &, 549 & ,649 &,- 658 & 2,488 \\
\hline & 1 & 0 &,- 580 & ,448 & 1,000 & $-1,863$ & ,703 \\
\hline & & 2 & ,253 & ,225 & 1,000 &,- 392 & ,898 \\
\hline & & 3 & ,335 & ,273 & 1,000 &,- 449 & 1,119 \\
\hline & 2 & 0 &,- 833 & ,404 & ,297 & $-1,990$ & ,324 \\
\hline & & 1 &,- 253 & ,225 & 1,000 &,- 898 & ,392 \\
\hline & & 3 & ,082 & 289 & 1,000 &,- 747 & ,910 \\
\hline & 3 & 0 &,- 915 & ,549 & ,649 & $-2,488$ & ,658 \\
\hline & & 1 &,- 335 & 273 & 1,000 & $-1,119$ & ,449 \\
\hline & & 2 &,- 082 & ,289 & 1,000 &,- 910 & ,747 \\
\hline \multirow[t]{12}{*}{ Cepacol } & 0 & 1 & $1,382^{*}$ & ,448 & ,029 & ,099 & 2,664 \\
\hline & & 2 & $1,558^{*}$ & ,404 & ,004 & 401 & 2,715 \\
\hline & & 3 & $2,215^{*}$ & ,549 & ,003 & ,642 & 3,788 \\
\hline & 1 & 0 & $-1,382^{*}$ & ,448 & ,029 & $-2,664$ &,- 099 \\
\hline & & 2 & , 177 & ,225 & 1,000 &,- 468 & ,822 \\
\hline & & 3 &, $833^{*}$ & 273 & ,032 & ,050 & 1,617 \\
\hline & 2 & 0 & $-1,558^{*}$ & ,404 & ,004 & $-2,715$ &,- 401 \\
\hline & & 1 &,- 177 & ,225 & 1,000 &,- 822 & ,468 \\
\hline & & 3 & ,657 & 289 & ,192 &,- 172 & 1,485 \\
\hline & 3 & 0 & $-2,215^{*}$ & ,549 & ,003 & $-3,788$ &,- 642 \\
\hline & & 1 &,$- 833^{*}$ & 273 & ,032 & $-1,617$ &,- 050 \\
\hline & & 2 &,- 657 & ,289 & ,192 & $-1,485$ & ,172 \\
\hline \multirow[t]{9}{*}{ Cepacol F } & 0 & 1 & 1,113 & ,448 & ,120 &,- 169 & 2,396 \\
\hline & & 2 & $2,052^{*}$ & ,404 &, 000 & ,895 & 3,209 \\
\hline & & 3 & $2,590^{*}$ & ,549 &, 000 & 1,017 & 4,163 \\
\hline & 1 & 0 & $-1,113$ & ,448 & ,120 & $-2,396$ & , 169 \\
\hline & & 2 &, $938^{*}$ & ,225 & ,002 & 293 & 1,583 \\
\hline & & 3 & $1,477^{*}$ & ,273 & ,000 & ,693 & 2,260 \\
\hline & 2 & 0 & $-2,052^{*}$ & ,404 & ,000 & $-3,209$ &,- 895 \\
\hline & & 1 &,$- 938^{*}$ & 225 & ,002 & $-1,583$ &,- 293 \\
\hline & & 3 &, 538 & 289 & ,447 &,- 290 & 1,367 \\
\hline
\end{tabular}




\begin{tabular}{|c|c|c|c|c|c|c|c|}
\hline & 3 & $\begin{array}{l}0 \\
1 \\
2\end{array}$ & $\begin{array}{c}-2,590^{*} \\
-1,477^{\star} \\
-, 538\end{array}$ & $\begin{array}{l}, 549 \\
, 273 \\
, 289\end{array}$ & $\begin{array}{l}, 000 \\
, 000 \\
, 447\end{array}$ & $\begin{array}{l}-4,163 \\
-2,260 \\
-1,367\end{array}$ & $\begin{array}{c}-1,017 \\
-, 693 \\
, 290\end{array}$ \\
\hline \multirow[t]{12}{*}{ Hipoclorito } & 0 & 1 & $3,798^{*}$ & ,448 & ,000 & 2,516 & 5,081 \\
\hline & & 2 & $5,118^{*}$ & ,404 & ,000 & 3,961 & 6,275 \\
\hline & & 3 & $5,122^{*}$ & ,549 & ,000 & 3,549 & 6,695 \\
\hline & 1 & 0 & $-3,798^{*}$ & ,448 & ,000 & $-5,081$ & $-2,516$ \\
\hline & & 2 & $1,320^{*}$ & ,225 & ,000 & 675 & 1,965 \\
\hline & & 3 & $1,323^{*}$ & 273 & ,000 & ,540 & 2,107 \\
\hline & 2 & 0 & $-5,118^{*}$ & ,404 & ,000 & $-6,275$ & $-3,961$ \\
\hline & & 1 & $-1,320^{*}$ & ,225 & ,000 & $-1,965$ &,- 675 \\
\hline & & 3 &, 003 & ,289 & 1,000 &,- 825 & ,832 \\
\hline & 3 & 0 & $-5,122^{*}$ & ,549 & ,000 & $-6,695$ & $-3,549$ \\
\hline & & 1 & $-1,323^{*}$ & 273 & ,000 & $-2,107$ &,- 540 \\
\hline & & 2 &,- 003 & ,289 & 1,000 &,- 832 & ,825 \\
\hline \multirow[t]{12}{*}{ Listerine } & 0 & 1 & 1,223 & ,448 & ,068 &,- 059 & 2,506 \\
\hline & & 2 & $2,877^{*}$ & ,404 & ,000 & 1,720 & 4,034 \\
\hline & & 3 & $3,423^{*}$ &, 549 & ,000 & 1,850 & 4,996 \\
\hline & 1 & 0 & $-1,223$ & ,448 & ,068 & $-2,506$ & ,059 \\
\hline & & 2 & $1,653^{*}$ & ,225 & ,000 & 1,008 & 2,298 \\
\hline & & 3 & $2,200^{*}$ & ,273 & , 000 & 1,416 & 2,984 \\
\hline & 2 & 0 & $-2,877^{*}$ & ,404 & ,000 & $-4,034$ & $-1,720$ \\
\hline & & 1 & $-1,653^{*}$ & ,225 & ,000 & $-2,298$ & $-1,008$ \\
\hline & & 3 &, 547 & ,289 & , 422 &,- 282 & 1,375 \\
\hline & 3 & 0 & $-3,423^{*}$ & ,549 & ,000 & $-4,996$ & $-1,850$ \\
\hline & & 1 & $-2,200^{*}$ & 273 & ,000 & $-2,984$ & $-1,416$ \\
\hline & & 2 &,- 547 & 289 & ,422 & $-1,375$ & 282 \\
\hline
\end{tabular}

Based on estimated marginal means

a. Adjustment for multiple comparisons: Bonferroni.

*. The mean difference is significant at the ,05 level. 